\title{
SOURCES OF QUATERNARY POTASSIC VOLCANIC ROCKS FROM WUdALIANCHI, CHINA: CONTROL BY TRANSTENSION AT THE LITHOSPHERE-ASTHENOSPHERE BOUNDARY LAYER
}

\author{
S. V. Rasskazov1, 2, I. S. Chuvashova1, 2, Yi-min Sun 3, Chen Yang3, \\ Zhenhua Xie $^{3}$, T. A. Yasnygina ${ }^{1}$, E. V. Saranina ${ }^{1}$, Zhenxing Fang ${ }^{3}$
}

\author{
${ }^{1}$ Institute of the Earth's Crust, Siberian Branch of RAS, Irkutsk, Russia \\ 2 Irkutsk State University, Irkutsk, Russia \\ ${ }^{3}$ Institute of Volcano and Mineral Spring, Heilongjiang Academy of Science, \\ Wudalianchi, Heilongjiang, China
}

\begin{abstract}
Introduction. Transtension is a system of stresses that tends to cause oblique extension, i.e. combined extension and strike slip. Syn-volcanic transtensional deformations of the lithosphere may provide two possible scenarios for control of magmatic processes. One scenario assumes ascending sub-lithospheric melts that mark the permeable lithosphere in a transtension area without melting of the lithospheric material; products of volcanic eruptions in such a zone show only the sub-lithospheric mantle material; components of magmatic liquids do not reveal any connection to the lithospheric structure. Another scenario yields a direct control of melting in lithospheric sources in an evolving transtensional structure. In this case, spatial-temporal changes of lithospheric and sub-lithospheric components are a direct indication of the evolving transtensional zone. In this paper, we present arguments in favor of the transtensional origin of the lithosphere-derived melting anomaly along the Wudalianchi volcanic zone, which are based on the study of components in the rocks sampled from the volcanic field of the same name.

Analytical methods. Trace elements were determined by ICP-MS using a mass-spectrometer Agilent 7500ce and isotopes using a mass-spectrometer Finnigan MAT 262. The methods used were described in the previous papers by Rasskazov et al. [2011] and Yasnygina et al. [2015]. Major oxides were measured by "wet chemistry".

Structural setting of the Wudalianchi zone. This zone extends north-south for $230 \mathrm{~km}$ at the northern circuit of the Songliao basin, subsided in the Late Mesozoic - Early Cenozoic (Fig. 1).

Timing of volcanism and variations of $\mathrm{K}_{2} \mathrm{O}$ contents in rocks from the Wudalianchi zone. Rocks, dated back to the Pliocene and Quaternary, show the stepwise increasing $\mathrm{K}_{2} \mathrm{O}$ content interval along the Wudalianchi zone from the southernmost Erkeshan volcanic field (5.6-5.8 wt \%) to the northernmost Xiaogulihe-Menlu volcanic field (2.0-9.5 wt \%) (Fig. 2).
\end{abstract}

Spatial-temporal clustering of volcanoes in the Wudalianchi field. In terms of the general Quaternary evolution of volcanism in Asia [Rasskazov et al., 2012], spatial-temporal distribution and compositional variations of volcanic products, we distinguish three time intervals of the volcanic evolution: (1) 2.5-2.0 Ma, (2) 1.3-0.8 Ma, and (3) $<0.6 \mathrm{Ma}$. The Central group of volcanoes showed persistent shifting of eruptions from Wohushan (1.33-0.42 Ma) to Bijiashan (0.45-0.28 Ma) to Laoheishan (1720-1721, possibly earlier) to Huoshaoshan (1721) (Figs 3, 4, 5). No spatial-temporal regularity of eruptions in volcanoes of the Erkeshan field and Western and Eastern groups of the Wudalianchi field reflected background activity.

Sampling. Representative sampling of rocks from the Wohushan-Huoshaoshan volcanic line was aimed to identify changing geochemical signatures along the whole volcanic line and in the course of eruptions in each volcano (Figs 3,6 , 7). For comparisons, the background volcanoes were also sampled.

Silica and alkalis oxides. On the total alkalis-silica (TAS) diagram (Fig. 8), data points of background rocks are distributed along the dividing lines between highly and moderately alkaline series mainly in tephriphonolite and trachyandesite fields with a few samples in the phonotephrite field. Background rocks from some volcanoes (e.g. Yaoquanshan and Weishan) are highly alkaline (phonotephrites and tephriphonolites). Background rocks from other volcanoes (Longmenshan, Jiaodebushan etc.) are moderately alkaline (mostly trachyandesites). In background rocks, $\mathrm{Na}_{2} \mathrm{O}+\mathrm{K}_{2} \mathrm{O}$ range from 8.6 to 9.7 wt \%, $\mathrm{SiO}_{2}$ from 51.6 to 55.0 wt \%. Phonotephrites from the Erkeshan field are comparable with the Wudalianchi background rocks of this type.

Data points of rocks from the Central group of volcanoes are also distributed along the discriminating line of highly and moderately alkaline series, mainly in the phonotephrite and trachyandesite fields. Almost all samples from the first volcano (Wohushan) fall within the data field of background rocks. Rock compositions of the second and third volcanoes (Bijiashan and Laoheishan) changed on each of them from similar to the background to the ones distinguished by the lower silica and alkalis contents. On the Bijiashan volcano, eruptions were exhibited by trachyande- 
sites of a lava shield and by basaltic trachyandesites and phonotephrites of a volcanic cone. The trachyandesites were comparable to the background rocks, the basaltic trachyandesites and phonotephrites differed from them. On the Laoheishan volcano, rocks were subdivided into three groups: (1) basaltic trachyandesites and phonotephrites, (2) trachyandesites, and (3) phonotephrites. The first group was recorded in pyroclastic material from the late volcanic cone and lavas from the northern bocca, the second group in pyroclastic material from the northwestern edge of the late crater, and the third group in bombs from its southwestern edge. On the fourth volcano (Huoshaoshan), rocks are basaltic trachyandesites and phonotephrites.

In terms of $\mathrm{Na}_{2} \mathrm{O}, \mathrm{K}_{2} \mathrm{O}$, and $\mathrm{SiO}_{2}$ contents, peripheral lavas of volcanic fans in the Bijiashan, Laoheishan, and Huoshaoshan volcanoes were close to background rocks. The contents of these oxides, differed from the background signatures, characterize rocks from volcanic cones in a linear progression that demonstrates the transition from compositions of the Wohushan volcano, close to background ones, through the intermediate values in the Bijiashan and Laoheishan volcanoes to the final compositions in the Huoshaoshan volcanic cone.

In the background rocks, $\mathrm{K}_{2} \mathrm{O}$ concentrations range from 4.8 to $6.0 \mathrm{wt} \%$ with its relative decrease in the rocks of the beginning and end of volcanic evolution. Initial lava flows with $\mathrm{K} 20$ contents as low as $4.0 \mathrm{wt} \%$ erupted along the Laoshantou - Old Gelaqiushan north-south locus from 2.5 to $2.0 \mathrm{Ma}$ and in the final cone of the Huoshaoshan volcano, erupted in 1721, fell to $3.2 \mathrm{wt} \%$. Since $1.3 \mathrm{Ma}$, irregular spatial-temporal distribution of volcanic activity reflected dominated background processes. Between 1.3 and 0.8 Ma, eruptions took place at the South Gelaqiushan volcano and along the west-east locus of the Lianhuashan, Yaoquanshan, West Jaodebushan, West Longmenshan volcanoes. In the last 0.6 Ma, three groups of volcanoes erupted: Western (North Gelaqiushan, Lianhuashan, Jianshan-Jianshanzi, Central (Wohushan, Bijiashan, Laoheishan, Huoshaoshan), and Eastern (Weishan, East Jaodebushan, Xiaogoshan, West and East Longmenshan, Molabushan). Background eruptions continued in the Western and Eastern groups, whereas the Central group displayed stepwise shift of activity from the southwest to the northeast. Under such a regular volcanic evolution, relative reduction of $\mathrm{K}_{2} \mathrm{O}$ abundances took place in final eruption products of the Huoshaoshan volcano (Fig. 9).

Other major oxides. Changes of rock compositions along the Wohushan-Huoshaoshan line, from the close to the background signatures at the first volcano (Wohushan) through the contrast major oxide contents at the Bijiashan and Laoheishan edifices to notably different from the background ones at the Huoshaoshan cone, are illustrated further by diagrams of $\mathrm{SiO}_{2}$ vs. $\mathrm{MgO}, \mathrm{Al}_{2} \mathrm{O}_{3}$ vs. $\mathrm{MgO}, \mathrm{CaO}$ vs. $\mathrm{MgO}$, and $\mathrm{P}_{2} \mathrm{O}_{5}$ vs. $\mathrm{MgO}$ (Figs 10, 11).

Trace elements. No sufficient difference is found between primitive mantle-normalized patterns plotted for rocks from different volcanoes (Fig. 13). Nevertheless, specific variations of rock compositions in the Central group of volcanoes close to the background and different from them are shown on the diagrams of $\mathrm{Ni}, \mathrm{Cr}, \mathrm{Rb}, \mathrm{Zr}, \mathrm{Ba}, \mathrm{Th}, \mathrm{Sr}$, and $\mathrm{La} / \mathrm{Yb}$ vs. MgO (Figs 12, 14, 15). A similar behavior was observed, on the one hand, for $\mathrm{Rb}$ and $\mathrm{Zr}$, on the other hand, for $\mathrm{Ba}$, $\mathrm{Th}, \mathrm{Sr}$, and $\mathrm{La} / \mathrm{Yb}$. In rocks from the Central group of volcanoes, which are compositionally close to the background ones, $\mathrm{Rb}$ concentrations increase from the first volcano (Wohushan) through the second (Bijiashan) to the third (Laoheishan). In rocks that differ from the background ones, $\mathrm{Rb}$ concentrations increase from the second to the fourth volcano and decrease in its final edifice. In rocks, close to the background ones, Zr concentrations decrease from the first to the second volcano and increase to the third volcano. In rocks, distinguished from background ones, relatively low concentrations of $\mathrm{Zr}$ at the first volcano change to elevated concentrations at the third and fourth volcanoes with relative decrease at the final Huoshaoshan edifice.

Discussion. Sub-lithospheric continuum of components under East Asia comprises a material from convective mantle domain with subducted slab (paleoslab) fragments of oceanic (paleooceanic) crust as well as delaminated lithospheric blocks of orogens. Volcanic rocks from the Wudalianchi field show a sub-lithospheric end-member, which belongs to this continuum. Lithospheric components of these rocks, however, have no connection with other sublithospheric components. We refer the Wudalianchi rocks to a sub-lithospheric-lithospheric cluster of components from the boundary between the lithosphere and sub-lithospheric convective mantle (Fig. 17). From the comparative analysis of $\mathrm{K}_{2} \mathrm{O}$, other major oxides, and trace elements in rocks of early and late eruption phases in the Central group of volcanoes, we infer that rocks were compositionally almost similar to the background ones in edifices of the first volcano (Wohushan), partially close to the background rocks and partly differed from them in edifices of the second and third volcanoes (Bijiashan, Laoheishan), and significantly different from the background rocks in the cone of the fourth volcano (Huoshaoshan) (Figs 18, 19). We suggest that magma generation under the Wudalianchi volcanic field was controlled by developing transtension of a layer at the base of the lithosphere that divided and shielded sources of the underlying homogeneous sub-lithospheric convective mantle and the overlying enriched heterogeneous lithosphere. The sub-lithospheric magma source had ${ }^{87} \mathrm{Sr} /{ }^{86} \mathrm{Sr}=0.7052$, sources of the boundary shielding layer the same and lower Sr-isotopic ratios, and sources of the overlying region the same and higher ratios (Fig. 20). Through the extremely low row of data points for rocks from the Huoshaoshan volcanic cone in ${ }^{87} \mathrm{Sr} /{ }^{86} \mathrm{Sr}$ vs. ${ }^{87} \mathrm{Rb} /{ }^{86} \mathrm{Sr}$ plot, we get an estimate of about $98 \mathrm{Ma}$ for the isotopic system closure at the base of the lithosphere with the initial ${ }^{87} \mathrm{Sr} /{ }^{86} \mathrm{Sr}$ apatite-related value 0.70485 and the underlying convective mantle domain with $\mathrm{Rb} / \mathrm{Sr}=0.092$ (Fig. 21). We infer that the development of transtension governed time and space of the locally introduced convective mantle component through the boundary shielding layer on background of melting enriched mantle material above the latter (Fig. 22). The 2.5-2.0 Ma local eruptions of sub-lithospheric liquids, derived from the axial part of the north-south zone of transtension, were followed by the 1.3-0.8 Ma background melts from a wider transtensional segment of the enriched lithospheric region. Afterwards, in the past $0.6 \mathrm{Ma}$, background melting of the enriched lithosphere sharply outlined edge portions of the transtensional segment, whereas simultaneous local sub-lithospheric melting propagated along a crack that originated within the boundary shielding layer due to concentrating tectonic forces at the central portion of the transtensional segment.

Key words: Potassic rocks; trace elements; Sr isotopes; transtension; asthenosphere; lithosphere; Wudalianchi; Northeast China 
For citation: Rasskazov S.V., Chuvashova I.S., Yi-min Sun, Chen Yang, Zhenhua Xie, Yasnygina T.A., Saranina E.V., Zhenxing Fang. 2016. Sources of Quaternary potassic volcanic rocks from Wudalianchi, China: Control by transtension at the lithosphere-asthenosphere boundary layer. Geodynamics \& Tectonophysics 7 (4), 555-592. doi:10.5800/GT-2016-7-4-0223.

\title{
ИСТОЧНИКИ ЧЕТВЕРТИЧНЫХ КАЛИЕВЫХ ВУЛКАНИЧЕСКИХ ПОРОД УДАЛЯНЬЧИ, КИТАЙ: КОНТРОЛЬ ТРАНСТЕНСИЕЙ В ПОГРАНИЧНОМ СЛОЕ ЛИТОСФЕРЫ-АСТЕНОСФЕРЫ
}

\author{
С. В. Рассказов ${ }^{1,2}$, И. С. Чувашова ${ }^{1,2}$, Йи-минь Сунь ${ }^{3}$, Чэнь Янг ${ }^{3}$, \\ Чжэньхуа Сие 3 , Т. А. Ясныгина'1, Е. В. Саранина 1 , Чжэньсин Фан ${ }^{3}$ \\ ${ }^{1}$ Институт земной коры СО РАН, Иркутск, Россия \\ ${ }^{2}$ Иркутский государственный университет, Иркутск, Россия \\ ${ }^{3}$ Институт вулканов и минеральных источников Хэйлунцзянской академии наук, \\ Удаляньчи, Хэйлунцзян, Китай
}

Аннотация: Введение. Транстенсия представляет собой систему напряжений, вызывающую косое растяжение литосферы - сочетание ее растяжения и сдвига. Синвулканические транстенсионные деформации литосферы могут обеспечить два возможных сценария контроля магматических процессов. Один из них предполагает восходящие подлитосферные расплавы, обозначающие проницаемые участки литосферы в области транстенсии без плавления литосферного материала. Продукты вулканических извержений в такой зоне представлены только подлитосферным мантийным материалом. Компоненты магматических расплавов не обнаруживают никакой связи с транстенсионной структурой литосферы. Другой сценарий выражается в непосредственном контроле плавления литосферных источников в эволюционирующей транстенсионной структуре. В этом случае пространственно-временная смена литосферных и подлитосферных компонентов служит прямым признаком эволюционирующей транстенсионной зоны. В настоящей статье мы приводим аргументы в пользу транстенсионной природы литосферной расплавной аномалии вулканической зоны Удаляньчи на основе исследований компонентов вулканических пород одноименного поля.

Аналитические методы. Содержания микроэлементов определены методом ICP-MS на масс-спектрометре Agilent 7500се, а отношения изотопов - на масс-спектрометре Finnigan MAT 262. Использованные методики охарактеризованы в предшествующих работах [Rasskazov et al., 2011; Yasnygina et al., 2015]. Петрогенные оксиды определены методом «мокрой химии».

Структурное положение зоны Удаляньчи. Зона простирается субмеридионально более чем на 230 км на северном замыкании бассейна Сунляо, образовавшегося в позднем мезозое - раннем кайнозое (рис. 1).

Возраст и содержания $\mathbf{K}_{2} \mathrm{O}$ в породах зоны Удаляньчи. Породы зоны Удаляньчи, датированные плиоценом и квартером, характеризуются последовательным увеличением интервала содержаний $\mathrm{K}_{2} \mathrm{O}$ от наиболее южного поля Еркешан (5.6-5.8 мас. \%) к наиболее северному полю Сяогулихе (2.0-9.5 мас. \%) (рис. 2)

Пространственно-временное группирование вулканов поля Удаляньчи. По пространственно-временному распределению и составу продуктов извержений мы различаем вулканические интервалы 2.5-2.0 млн лет назад, 1.3-0.8 млн лет назад и последние 0.6 млн лет. В линии четырех вулканов Центральной группы имела место единая возрастная последовательность извержений: Уохушан (1.33-0.42 млн лет назад), Бидзиашан (0.45-0.28 млн лет назад), Лаохейшан (1720-1721 гг., возможно, более ранние извержения) и Хуошаошан (1721 г.) (рис. 3-5). Отсутствие пространственно-временной регулярности извержений вулканов на поле Еркешан и в Западной и Восточной группах вулканов поля Удаляньчи отражало фоновую активность. В фоновых породах определен диапазон концентраций $\mathrm{K}_{2} \mathrm{O}$ 4.8-6.0 мас. \% с относительным снижением содержаний этого оксида в породах начала и конца вулканической эволюции. В начальных лавовых потоках, излившихся в субмеридиональной полосе Лаошантоу - Древний Гелацюшан в интервале 2.5-2.0 млн лет назад, содержания $\mathrm{K}_{2} \mathrm{O}$ составляли 3.9-5.2 мас. \%, на финальном конусе вулкана Хуошаошан, образовавшемся в 1721 г., - снижались до 3.2 мас. \%. Фоновая активность проявилась на вулкане Южный Гелацюшан и вулканах субширотной полосы Лианхуашан, Йаоцюаншан, Западный Дзяодебушан, Западный Лонгменшан во временном интервале 1.3-0.8 млн лет назад. В последние 0.6 млн лет извергались вулканы трех групп: Западной (Северный Гелацюшан, Лианхуашан, Дзианшан-Дзиамшанзи), Центральной (Уохушан, Бидзиашан, Лаохейшан, Хуошаошан) и Восточной (Уэйшан, Восточный Дзяодебушан, Сяогошан, Западный и Восточный Лонгменшан, Молабушан). В Западной и Восточной группах фоновая активность продолжалась, в то время как в Центральной группе активность вулканов последовательно смещалась с юго-запада на северо-восток. Такая упорядоченная вулканическая эволюция сопровождалась относительным снижением содержаний $\mathrm{K}_{2} \mathrm{O}$ в продуктах финальных извержений вулкана Хуошаошан. 
Опробование. Представительное опробование пород вулканов в линии Уохушан-Хуошаошан проводилось с целью выявления меняющихся геохимических характеристик в ходе извержений на каждом вулкане и от вулкана к вулкану (рис. $3,6,7)$. Для сопоставлений использованы данные по составу пород вулканов фоновых извержений.

Оксиды кремнезема и щелочей. На классификационной диаграмме щелочи - кремнезем (рис. 8) фигуративные точки пород фоновых извержений сконцентрированы вдоль разделительной линии серий высокой и умеренной щелочности преимущественно в полях тефрифонолитов и трахиандезитов, в меньшей степени - в поле фонотефрита. Фоновые породы одних вулканов (например, Йаоцюаншан и Уэйшан) имеют высокощелочной (фонотефритовый и тефрифонолитовый) состав, фоновые породы других вулканов (Лонгменшан, Дзяодебушан и др.) - умеренно щелочной (трахиандезитовый). Сумма щелочей $\mathrm{Na}_{2} \mathrm{O}+\mathrm{K}_{2} \mathrm{O}$ в фоновых породах находится в интервале 8.6-9.7 мас. \%, $\mathrm{SiO}_{2}$ - в интервале 51.6-55.0 мас. \%. Фонотефриты поля Еркешан сопоставимы с фоновыми породами поля Удаляньчи.

Фигуративные точки пород Центральной группы вулканов также распределяются вдоль разделительной линии серий высокой и умеренной щелочности диаграммы щелочи - кремнезем, преимущественно в полях фонотефритов и трахиандезибазальтов. Почти все образцы первого вулкана (Уохушан) находятся в фигуративном поле фоновых пород. Составы пород второго и третьего вулканов (Бидзиашан и Лаохейшан) менялись в ходе извержений каждого из них от близких к фоновым до отличавшихся от фоновых. На вулкане Бидзиашан продукты вулканических извержений были представлены трахиандезитами периферии щитовой постройки и трахиандезибазальтами-фонотефритами вулканического конуса. Трахиандезиты были сопоставимы с фоновыми породами, трахиандезибазальты-фонотефриты заметно отличались от них. На вулкане Лаохейшан выделилось три группы пород: 1) трахиандезибазальты-фонотефриты, 2) трахиандезиты и 3) фонотефриты. Породы первой группы представлены в пирокластическом материале позднего вулканического конуса и в лавовых потоках северной бокки, породы второй группы - в пирокластическом материале западной кромки позднего кратера, породы третьей группы - в бомбах его юго-западной кромки. По соотношениям $\mathrm{Na}_{2} \mathrm{O}, \mathrm{K}_{2} \mathrm{O}$ и $\mathrm{SiO}_{2}$ породы периферических лавовых шлейфов вулканов Бидзиашан, Лаохейшан и Хуошаошан сопоставимы с продуктами фоновых извержений. Содержания этих оксидов, отличающиеся от фоновых, свойственны породам линии вулканических конусов, в которых проявился переход от составов пород вулкана Уохушан, близких к фоновым, через промежуточные составы пород вулканов Бидзиашан и Лаохейшан к финальным составам пород вулканического конуса Хуошаошан (рис. 9).

Другие петрогенные оксиды. Смена составов пород вдоль линии Центральной группы вулканов от близких к фоновым в первой постройке (Уохушан) через контрастные в постройках Бидзиашан и Лаохейшан к заметно отличающимся от фоновых на конусе вулкана Хуошаошан дополнительно иллюстрируется диаграммами $\mathrm{SiO}_{2}-\mathrm{MgO}, \mathrm{Al}_{2} \mathrm{O}_{3}-\mathrm{MgO}, \mathrm{CaO}-\mathrm{MgO}$ и $\mathrm{P}_{2} \mathrm{O}_{5}-\mathrm{MgO}$ (рис. 10, 11).

Микроэлементы. Для пород разных вулканов не отмечено заметных различий в элементных спектрах, нормированных к примитивной мантии (рис. 13). Особые вариации пород вулканов Центральной группы, близких к фоновым и отличающихся от них, подчеркнуты, тем не менее, на диаграммах $\mathrm{Rb}-\mathrm{MgO}, \mathrm{Zr}-\mathrm{MgO}, \mathrm{Ba}-$ MgO, Th-MgO, Sr-MgO и La/Yb-MgO (рис. 12, 14-15). Сходное поведение обнаружено, с одной стороны, для Rb и $\mathrm{Zr}$, с другой стороны - для Ba, Th, Sr и La/Yb. B составах пород вулканов Центральной группы, близких к фоновым, наблюдалось последовательное повышение концентраций Rb от первого вулкана линии (Уохушан) через второй вулкан (Бидзиашан) к третьему вулкану (Лаохейшан). В породах, отличающихся от фоновых, выявлены общие повышенные концентрации Rb от второго до четвертого вулкана линии и относительное снижение концентраций этого элемента в финальной постройке четвертого вулкана. В породах, близких к фоновым, концентрации Zr снижаются от первого вулкана ко второму, а к третьему - возрастают. В породах, отличающихся от фоновых, сравнительно низкие концентрации Zr первого вулкана сменяются повышенными концентрациями третьего и четвертого вулканов с дальнейшим относительным снижением концентраций этого элемента в финальной постройке четвертого вулкана.

Обсуждение. Подлитосферный компонентный континуум в Восточной Азии содержит материал из домена конвектирующей области мантии с субдуцированными слэбовыми (палеослэбовыми) фрагментами океанической (палеоокеанической) коры, а также деламинированных литосферных блоков орогенов. Вулканические породы поля Удаляньчи содержат подлитосферный конечный компонент, который принадлежит к этому континууму. Литосферные компоненты этих пород, однако, не имеют никакого отношения к другим подлитосферным компонентам. Породы Удаляньчи относятся к подлитосферно-литосферному компонентному кластеру, характеризующему границу между литосферой и подлитосферной конвектирующей мантией (рис. 17). Из анализа содержаний $\mathrm{K}_{2} \mathrm{O}$, других петрогенных оксидов и микроэлементов в породах ранних и поздних фаз извержений Центральной группы вулканов следует, что составы построек первого вулкана (Уохушан) почти не отличались от фоновых, второго и третьего вулканов (Бидзиашан и Лаохейшан) были частично близки к фоновым и частично отличались от них, а четвертого (Хуошаошан) существенно отличались от фоновых (рис. 18, 19). Предполагается, что генерация магм под вулканическим полем Удаляньчи контролировалась развитием транстенсии в граничном слое основания литосферы, разделявшем и экранировавшем источники подстилающей гомогенной подлитосферной конвектирующей мантии и перекрывающей гетерогенной обогащенной литосферы. Подлитосферный источник магм обладал отношением ${ }^{87} \mathrm{Sr} /{ }^{86} \mathrm{Sr}=0.7052$, источники экранирующего слоя - таким же и более низкими отношениями, источники вышележащей литосферы - такими же и более высокими отношениями (рис. 20). По предельно низкому ряду фигуративных точек пород вулканического конуса Хуошаошан на диаграмме ${ }^{87} \mathrm{Sr} /{ }^{86} \mathrm{Sr}-{ }^{87} \mathrm{Rb} / 86 \mathrm{Sr}$ получена оценка закрытия изотопной системы в подошве литосферы около 98 млн лет с начальным ${ }^{87} \mathrm{Sr} / 86 \mathrm{Sr}$ значением 0.70485 в апатитсодержащем источнике и подстилающем домене конвектирующей мантии с $\mathrm{Rb} / \mathrm{Sr}=0.092$ (рис. 21). Развитие транстенсии определяло время и место локального поступления компонента конвектирующей мантии изпод граничного экранирующего слоя на фоне плавления обогащенного материала над ним (рис. 22). Локаль- 
ные извержения подлитосферных выплавок из осевой части субмеридиональной магистральной зоны транстенсии интервала 2.5-2.0 млн лет назад сменились в интервале 1.3-0.8 млн лет назад извержениями фоновых выплавок из более широкого транстенсионного сегмента обогащенной области литосферы. В последние 0.6 млн лет фоновые выплавки из обогащенной литосферы резче обозначили краевые части транстенсионного сегмента, а локальные подлитосферные выплавки распространились вдоль разрыва, образовавшегося в граничном экранирующем слое при концентрации тектонических усилий в центральной части транстенсионного сегмента.

Ключевые слова: калиевые породы; микроэлементы; изотопы Sr; транстенсия; астеносфера; литосфера; Удаляньчи; Северо-Восточный Китай

\section{INTRODUCTION}

Transtension is a system of stresses that tends to cause oblique extension, i.e., combined extension and strike slip [Neuendorf et al., 2011]. Syn-volcanic transtensional deformations of the lithosphere may provide two possible scenarios for control of magmatic processes. One scenario assumes ascending sub-lithospheric melts that penetrate through the lithosphere in a transtension area without melting the lithospheric material. Products of volcanic eruptions in such a zone show only the sub-lithospheric mantle material. Components of magmatic liquids do not reveal any connection to a lithospheric structure. This was the case for 16-13 Ma volcanic eruptions in the Vitim Plateau [Chuvashova et al., 2016]. Another scenario yields a direct control of melting in lithospheric sources in an evolving transtensional structure. In this case, spatial-temporal changes of lithospheric and sub-lithospheric components are a direct indication of the evolving transtensional zone.

In East Asia, lateral motions are well recognized along north-south faults (e.g., Tan-lu, Tsushima, Central Sikhote-Alin). Right- and left-lateral displacements in some of these faults, however, are controversial [Jolivet et al., 1994; Gilder et al., 1999; Zhang et al., 2003; Utkin, 2013]. It is not clear whether these faults affected the lithospheric magma sources. In this paper, we present arguments in favor of transtensional origin of the lithosphere-derived melting anomaly along the Wudalianchi volcanic zone that extends north-south for $230 \mathrm{~km}$ at the northern circuit of the Songliao basin, central Heilongjiang Province, Northeast China. The Wudalianchi volcanic zone is exhibited by rocks of potassic series distributed along a chain of volcanic fields (from south to north): Erkeshan - Wudalianchi - Keluo - Xiaogulihe-Menlu [Wang, Chen, 2005; Zhao et al., 2014]. Three volcanic fields (Wudalianchi, Erkeshan, and Keluo) were described also as the WEK zone [Zhang et al., 1991, 1995].

The potassic rocks were examined together with Cenozoic potassic-sodic basalts from the whole East
China within a common continuum of mantle sources as the end-member with enriched $\mathrm{Sr}$ and $\mathrm{Nd}$ isotopic signatures $\left({ }^{87} \mathrm{Sr} /{ }^{86} \mathrm{Sr}>0.7055,{ }^{143} \mathrm{Nd} /{ }^{144} \mathrm{Nd}<0.5123\right)$ and low $\mathrm{Pb}$ isotopic ratios $\left(206 \mathrm{~Pb} / 204 \mathrm{~Pb}<16.55,{ }^{208} \mathrm{~Pb} / 204 \mathrm{~Pb} \sim\right.$ 36.5) [Zou et al., 2000]. From such a taxonomy of sources, the most enriched Wudalianchi-type component was assumed to occur in the mantle of any part of East China or at least within the asthenospheric mantle domain of the North China craton and Xing-Meng block [Choi et al., 2006; Chen et al., 2007]. The common continuum of Cenozoic rocks was assumed also to exhibit the direct generation of the erupted Wudalianchi liquids from the mantle transition zone [Kuritani et al., 2013]. This idea was based on the crystallization temperature estimate for the nucleus of olivine phenocrysts from rocks of the Laoheishan and Huoshaoshan volcanoes, which exceeded the temperature estimate assuming a conductive heat transfer in the lithosphere.

Firstly detected essential geochemical differences between potassic and potassic-sodic basalts from East China [Zhang et al., 1995] have been confirmed in many studies. Sources of potassic basalts were referred to the enriched post-Archean sub-continental lithospheric mantle, comparable to the global EM1 OIB component, unlike sources of potassic-sodic basalts that were considered as derivatives from the depleted sub-lithospheric mantle, comparable with the depleted global DMM OIB component [Zhang et al., 1995; Zou et al., 2003, 2008; Choi et al., 2006; Chen et al., 2007; Chu et al., 2013]. Significant discrepancies were found between geochemical signatures of mantle xenoliths from potassic-sodic basalts of China and their host lavas [Basu et al., 1991]. On the contrary, geochemical characteristics similar (although not identical) to those of host lavas were defined in xenoliths of spinel peridotites from potassic volcanic rocks [Zhang et al., 2000, 2011; Chu et al., 2013]. In such a change of compositional relations between mantle xenoliths and volcanic rocks, clear specifics of lithospheric origin of the potassic rocks from the Wudalianchi zone stood out, unlike sub-lithospheric nature of potassic-sodic basalts from other areas. Potassic melts were considered to be generated 
from a phlogopite-bearing garnet peridotite source [Zhang et al., 1995, 2000; Zou et al., 2003; Chuvashova et al., 2009; Chu et al., 2013].

Rock compositions from the Laoheishan and Huoshaoshan volcanoes were subdivided to groups with various $\mathrm{SiO}_{2}, \mathrm{~K}_{2} \mathrm{O}$, and other major oxide contents. From mutually convergent trends of data points for rocks from the Wudalianchi and Nuominhe volcanic fields on a plot of initial ${ }^{87} \mathrm{Sr} /{ }^{86} \mathrm{Sr}$ versus $10^{3} / \mathrm{Sr}$, the initial ${ }^{87} \mathrm{Sr} /{ }^{86} \mathrm{Sr}=0.7052$ was accepted as a signature for a common component, the origin of which was explained by the involvement in melting of a material from the sub-lithospheric convective mantle. From calculations of mixing models in coordinates of $\mathrm{Sr}$ and $\mathrm{Pb}$ isotope ratios, sources for potassic liquids were referred to the lithosphere-asthenosphere boundary and mostly to the sub-continental lithosphere [Chuvashova et al., 2009; Rasskazov et al., 2011].

Rocks from the Wudalianchi zone remain geochemically poorly studied. Compositions of most volcanoes have not been described yet or have been characterized by one or two rock compositions. The controversy over the issue of potassic volcanic rock sources requires additional arguments based on detail sampling of eruption products. To elaborate the idea of the spatial-temporal evolution of magmatic processes at the lithosphere-asthenosphere boundary and connect these processes with tectonic features of the study area, we present and discuss the data on the WohushanHuoshaoshan volcanic line that has the key significance for understanding the structure of a source region for volcanic rocks of the Wudalianchi field.

\section{ANALYTICAL METHODS}

Analytical studies of rock samples were performed in the Laboratory for Isotopic and Geochronological Studies of the Institute of the Earth's Crust SB RAS. Trace elements were determined by ICP-MS technique using a mass-spectrometer Agilent 7500ce and isotopes using a mass-spectrometer Finnigan MAT 262. The methods used were described in the previous papers by Rasskazov et al. [2011] and Yasnygina et al. [2015]. Major oxides were measured by "wet chemistry".

\section{STRUCTURAL SETTING OF THE WUDALIANCHI ZONE}

Terranes of the study area were initially assembled during the Early Paleozoic and accreted to the North China craton by the Xilamulun River-Yanji Suture Zone at the end of the Permian [Wang et al., 2016]. In the eastern part of the Central Asian Orogenic Belt, Middle Phanerozoic oceanic crust subducted to the south un- der the North China craton and to the north under the Erguno-Hinggan block. The Sonidzuoqi-Xilinhot magmatic arc was active at about 320 and $280 \mathrm{Ma}$, as it was inferred in the study of zircons from sandstones of the southern, central, and northern Greater Hinggan. This arc included the Zhengdashan pluton, located to the south-east of Nenjiang city. The Nenjiang-Balihan leftlateral strike slip fault bounded the western side of the Songliao basin that was subsided in the Late Mesozoic Early Cenozoic [Han et al., 2012a, 2012b; Wang et al., 2016] (Fig. 1, b). This displacement might result in stretching crust of the Songliao basin limited by the area of the northern end of the Wudalianchi zone.

According to Wang et al. [2007], the Songliao basin includes the lower unit, characterized by a faultbounded 130-110 Ma sequence of intercalated volcanic, pyroclastic and epiclastic rocks (geochemically active continental margin type) and the upper unit dominated by non-marine sag-style sedimentary sequence of siliciclastics and minor carbonates. In the recent study by Wang et al. [2016], it was suggested that the Aptian and pre-Aptian retroarc evolution was followed by the Albian to Companian strike-slip motions under transtension and afterwards (since the Maastrichtian) by inverse development under compression. The three tectonic cycles are referred to the syn-rift (150-105 $\mathrm{Ma})$, post-rift (105.0-79.1 Ma), and structural inversion (79.1-64.0 Ma) stages. Volcanism was characteristic of the syn-rift and post-rift stages.

Volcanic fields of the Wudalianchi zone are controlled by the Xiaogulihe-Wudalianchi fault - one of the structural elements at the northern circuit of the Songliao basin [Wang, Chen, 2005] (Fig. 1). Potassic volcanism is limited to the north by the Greater Hinggan Frontal and Nenjiang faults and to the south by the Central Fault of the Songliao basin. The Keluo and Xiaogulihe-Menlu volcanic fields are separated from each other by the Erenhot-Hegenshan suture. The Keluo, Wudalianchi, and Erkeshan volcanic fields correspond to structural elements, characterized by local thinning of the crust to $33.5 \mathrm{~km}$, and occupy the southeastern flank of the Nenjiang-Balihan fault with the thinned crust (Fig. 1, a), whereas the Nuominhe field reside in its northwestern flank with the thickened crust. The transition from the Songliao basin to the Greater Hinggan corresponds to the Marginal Gravity Step that extends along the entire eastern margin of Asia with stagnating slabs beneath [van der Hilst et al., 1991; Fukao et al., 1992, 2001; Bijwaard et al., 1998; Zhao, 2009]. In East Asia, the crust and lithospheric mantle is considerably thinner than in Inner Asia. Under the central part of the Songliao basin, the lithosphere is as thin as $80 \mathrm{~km}$, getting thicker towards its northern part [Zhang et al., 1995].

It is noteworthy also that potassic rocks are located almost in front of the currently active directly-sub- 


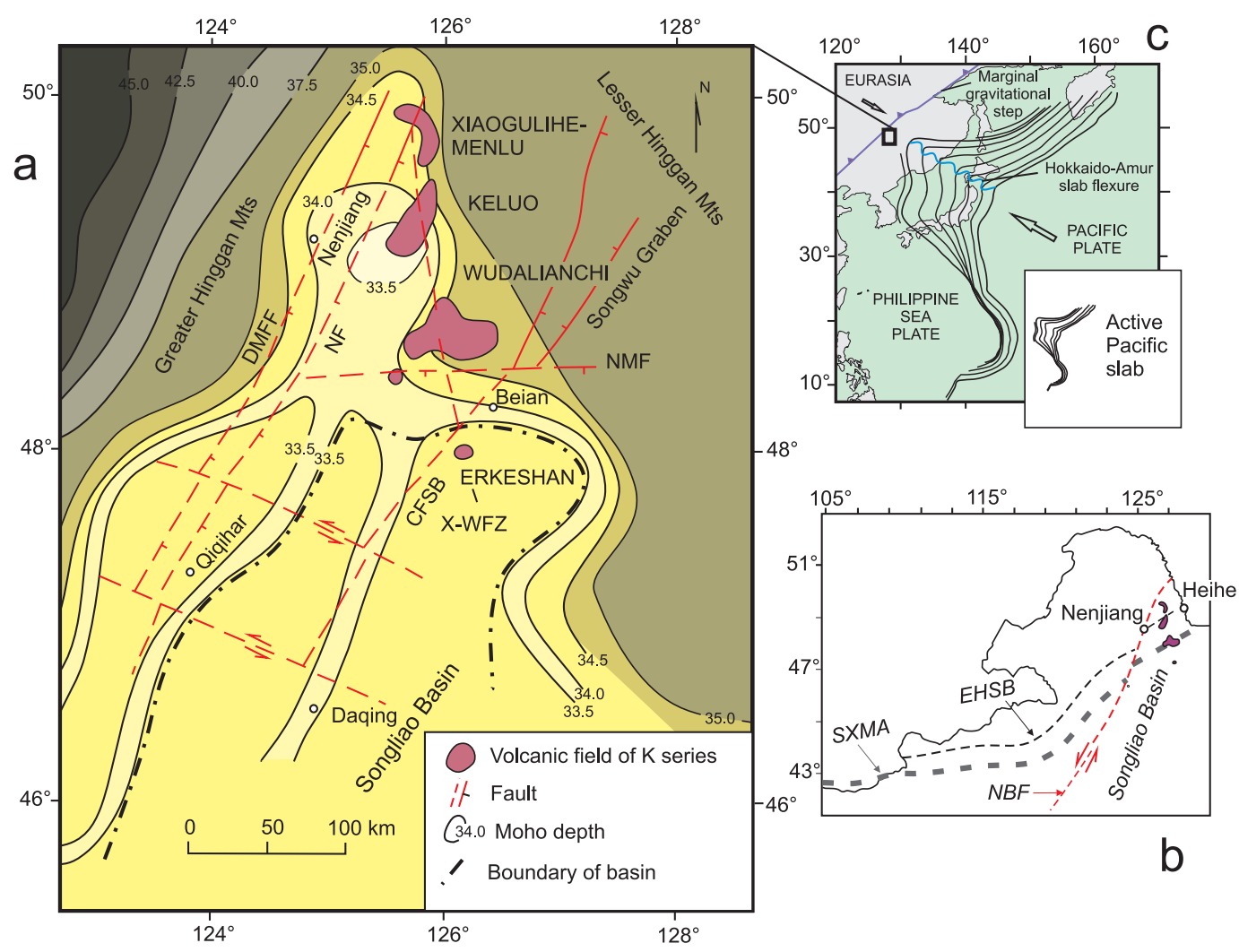

Fig. 1. Location of the Wudalianchi volcanic zone relative to (a) crustal structural elements of the Late Mesozoic - Early Cenozoic Songliao basin, $(b)$ the Nenjiang-Balihan strike-slip fault (NBF) bounded the Songliao basin in the west, and (c) the currently subducted Pacific slab.

In $(a)$, the Wudalianchi volcanic zone corresponds to the Xiaogulihe-Wudalianchi fault (X-WFZ), stretching from the Greater Hinggan Frontal fault (GHFF) and Nenjiang fault (NF) to the Central Fault of the Songliao Basin (CFSB). Scheme (b) shows the Erenhot-Hegenshan Suture Belt (EHSB) and Sonidzuoqi-Xilinhot Magmatic Arc (SXMA). In (c), contour lines of the depths in increments of $50 \mathrm{~km}$ to the top of seismically active subducting Pacific slab [Gudmundsson, Sambridge, 1998] show the Hokkaido-Amur slab flexure [Rasskazov, Chuvashova, 2016] and the Marginal Gravitational Step of East Asia [Romanovsky, 1999; Li et al., 2006]. (a) and (b) are modified after [Wang, Chen, 2005] and [Han et al., 2012a, 2012b], respectively.

Рис. 1. Расположение вулканической зоны Удаляньчи относительно (a) структурных элементов коры позднемезозойско-раннекайнозойского бассейна Сунляо, (b) сдвигового разлома Нэньцзян-Балихан (NBF - Nenjiang-Balihan), ограничивающего с запада бассейн Сунляо и (c) ныне субдуцирующего Тихоокеанского слэба.

На схеме (a) вулканическая зона Удаляньчи соответствует разломной зоне Сяогулихе-Удаляньчи (X-WFZ), протягивающейся от Фронтального разлома Большого Хингана (DMFF) и разлома Нэньцзян (NF) до Центрального разлома бассейна Сунляо (CFSB). На схеме $(b)$ показаны: шовный пояс Эренхот-Хегеншан (EHSB - Erenhot-Hegenshan Suture Веlt) и магматическая дуга Сонидзуоки-Силинхот (SXMA - Sonidzuoqi-Xilinhot Magmatic Arc). На схеме (c) по изолиниям глубин с шагом 50 км кровли субдуцирующего Тихоокеанского слэба [Gudmundsson, Sambridge, 1998] показаны Хоккайдо-Амурская слэбовая флексура [Rasskazov, Chuvashova, 2016] и краевая гравитационная ступень Восточной Азии [Romanovsky, 1999; Li et al., 2006]. Схемы (a) и (b) приведены, соответственно, по работам [Wang, Chen, 2005] и [Han et al., 2012a, 2012b] с изменениями.

ducted Hokkaido-Amur flexure of the Pacific slab (Fig. 1, c). Under the Wudalianchi area, the Heilongjiang S-wave low-velocity anomaly was defined in tomographic models of Yanovskaya and Kozhevnikov [2003] and Wei et al. [2012] at depth of about $100 \mathrm{~km}$.

\section{TIMING OF VOLCANISM AND VARIATIONS OF $\mathrm{K}_{2} \mathrm{O}$ CONTENTS IN ROCKS FROM THE WUDALIANCHI ZONE}

Volcanism of the Wudalianchi zone was concentrated mainly in the Keluo and Wudalianchi fields. In the former, eruptions occurred since $4.6 \mathrm{Ma}$, in the latter since $2.5 \mathrm{Ma}$. The older ages of rocks from Keluo [Zhang et al., 1991, 1995] were not confirmed [Zhao et al., 2014; unpublished data of the authors]. On the small Erkeshan field, located at the southern end of the zone, volcanic eruptions of three cones (two twin volcanoes) occurred in the time interval from 0.56 to $0.36 \mathrm{Ma}$ [Wang et al., 1996; Wang, Chen, 2005; Guide book..., 2010]. On the Xiaogulihe-Menlu field, situated at the northern end of the zone, eruptions were referred to the Holocene and compositions of volcanic rocks were described as ultrapotassic [Wang, Chen, 2005]. Such 
rocks with $\mathrm{K}_{2} \mathrm{O}=8.7-9.5$ wt $\%$ and $\mathrm{K}_{2} \mathrm{O} / \mathrm{Na}_{2} \mathrm{O}=4.3-4.9$ [Wee, 2002] were found in the northwestern part of the Xiaogulihe-Menlu field, whereas rocks with $\mathrm{K}_{2} \mathrm{O}=1.96-$ 2.14 wt \%, dated at 1.00-1.28 Ma, were located in its southeastern part [Zhao et al., 2014]. In rocks from the Wudalianchi zone, these $\mathrm{K}_{2} \mathrm{O}$ contents are the lowest.

Histograms in Fig. 2 demonstrate a change of $\mathrm{K}_{2} \mathrm{O}$ contents in rocks from a narrow range of 5.6-5.8 wt \% in the Erkeshan field to wider intervals in the Wudalianchi and Keluo fields that show decreasing values to $3.2 \mathrm{wt} \%$. In rocks from the Keluo field, this interval is expanded also due to increasing $\mathrm{K}_{2} \mathrm{O}$ to $7.0 \mathrm{wt} \%$. In the Xiaogulihe-Menlu field, the least and most potassic rocks yield a total range from 2.0 to 9.5 wt $\% \mathrm{~K}_{2} \mathrm{O}$. In this paper, we focus on causes of decreasing $\mathrm{K}_{2} \mathrm{O}$ contents in rocks from the Wudalianchi volcanic field. Variations of $\mathrm{K}_{2} \mathrm{O}$ contents in the Keluo and XiaoguliheMenlu rocks will be considered elsewhere.

Volcanic rocks from the Xunke field to the east of the Wudalianchi zone are dated back to the Pliocene and Quaternary [Liu et al., 2001; Zhao et al., 2014].

\section{SPATIAL-TEMPORAL CLUSTERING OF VOLCANOES IN THE WUDALIANCHI FIELD}

The main Wudalianchi field of 14 volcanoes [Zhang et al., 1995; Wang et al., 1996; Guide book..., 2010] (Fig. 3 ) is supplemented to the west and southwest with three small volcanic areas: (1) Lianhuashan edifices, (2) Jianshan, Jianshanzi edifices, and (3) Laoshantou lava flow [Zhao et al., 2014]. Most of the volcanoes have lava pedestals, crowned by slag or slag-lava cones. Diameters at the bases of such cones are 500-1200 m, and heights range from 40 to $170 \mathrm{~m}$. As a rule, the cones contain craters. The spatial distribution of the cones was described in [Wang et al., 1996; Wang, Chen, 2005; Guide book..., 2010; Zhao et al., 2014] with respect to the northeastern or both northeastern and northwestern volcanic lines.

Potassium-argon ages were obtained for both the main Wudalianchi field and satellite volcanic areas. Seven volcanic phases were defined [Wang et al., 1996; Liu, Taniguchi, 2001; Liu et al., 2001; Wang, Chen, 2005; Guide book..., 2010; Zhao et al., 2014]. Considering the general Quaternary evolution of volcanism in Asia [Rasskazov et al., 2012], spatial-temporal distribution and compositional variations of volcanic products, we distinguish three time intervals of the volcanic evolution: (1) 2.5-2.0 Ma, (2) 1.3-0.8 Ma, and (3) <0.6 Ma.

The lower limit of the initial eruptive interval was constrained by the $\mathrm{K}-\mathrm{Ar}$ age of $2.52 \pm 0.06 \mathrm{Ma}$ for the Laoshantou flow [Zhao et al., 2014], and the upper limit was designated by the age of $2.076 \pm 0.054 \mathrm{Ma}$ for the Old Gelaqiushan flow [Wang et al., 1996]. In the 1.3-0.8 Ma interval, eruptions occurred in the Wohushan and
West Longmenshan volcanoes at about 1.3 Ma, in the Yaoquanshan volcano at about $0.93 \mathrm{Ma}$, and in the Lianhuashan, West Jiaodebushan, South Gelaqiushan volcanoes at about $0.8 \mathrm{Ma}$. Volcanoes of this interval distributed along a west-eastern bend, with the exception of the South Gelaqiushan volcano, activation of which together with the Lianhuashan volcano marked the northeastern line of eruptions. In the last $0.6 \mathrm{Ma}$, three groups of volcanoes erupted: Western (North and South Gelaqiushan, Lianhuashan, Jianshan-Jianshanzi), Central (Wohushan, Bijiashan, Laoheishan, Huoshaoshan), and Eastern (Weishan, East Jiaodebushan, Xiaogushan, West and East Longmenshan, Molabushan). As compared to the edifices of the 1.3-0.8 Ma interval, those of the last $0.6 \mathrm{Ma}$ shifted northeastwards in the Eastern group and southwestwards in the Western group (Fig. 4). The final eruptions took place in the Central group on the Laoheishan and Huoshaoshan volcanoes in 1720-1721 AD [Liu and Taniguchi, 2001], in the Western group on the Jianshan volcano at about $0.12 \mathrm{Ma}$, and in the Eastern group on the East Longmenshan and Xiaogushan volcanoes at about 0.19-0.17 Ma or 0.32 Ma [Zhao et al., 2014].

The Central group of volcanoes showed persistent shift of eruptions from Wohushan (1.33-0.42 Ma) to Bijiashan (0.45-0.28 Ma) to Laoheishan (1720-1721, possibly earlier) to Huoshaoshan (1721). No spatialtemporal regularity of eruptions in volcanoes of the Erkeshan field and Western and Eastern groups of the Wudalianchi field reflected background activity.

Fig. 5 illustrates a jumping character of volcanic shift along the Wohushan-Huoshaoshan line. Activity of the first (Wohushan) volcano ceased simultaneously with the beginning activity of the second (Bijiashan) volcano (within error of $\mathrm{K}-\mathrm{Ar}$ dating). Further, eruptions at the second volcano stopped simultaneously with transfer of activity to the third (Laoheishan) volcano. Likewise, volcanic activity jumped from the third to the fourth volcano (from Laoheishan to Huoshaoshan) in 1720-1721.

\section{SAMPLING}

Representative sampling of rocks from the Wohushan-Huoshaoshan volcanic line was aimed to identify changing geochemical signatures along the whole volcanic line and in the course of eruptions in each volcano. For comparisons, the background volcanoes were also sampled with a priority to the Yaoquanshan and Weishan volcanoes, located in close proximity to the Wohushan-Huoshaoshan line. Temporal inconsistency of eruptions assumes that these two volcanoes belong to the Eastern group.

Data on chemical compositions of rocks from the Wudalianchi area have been published mostly with 


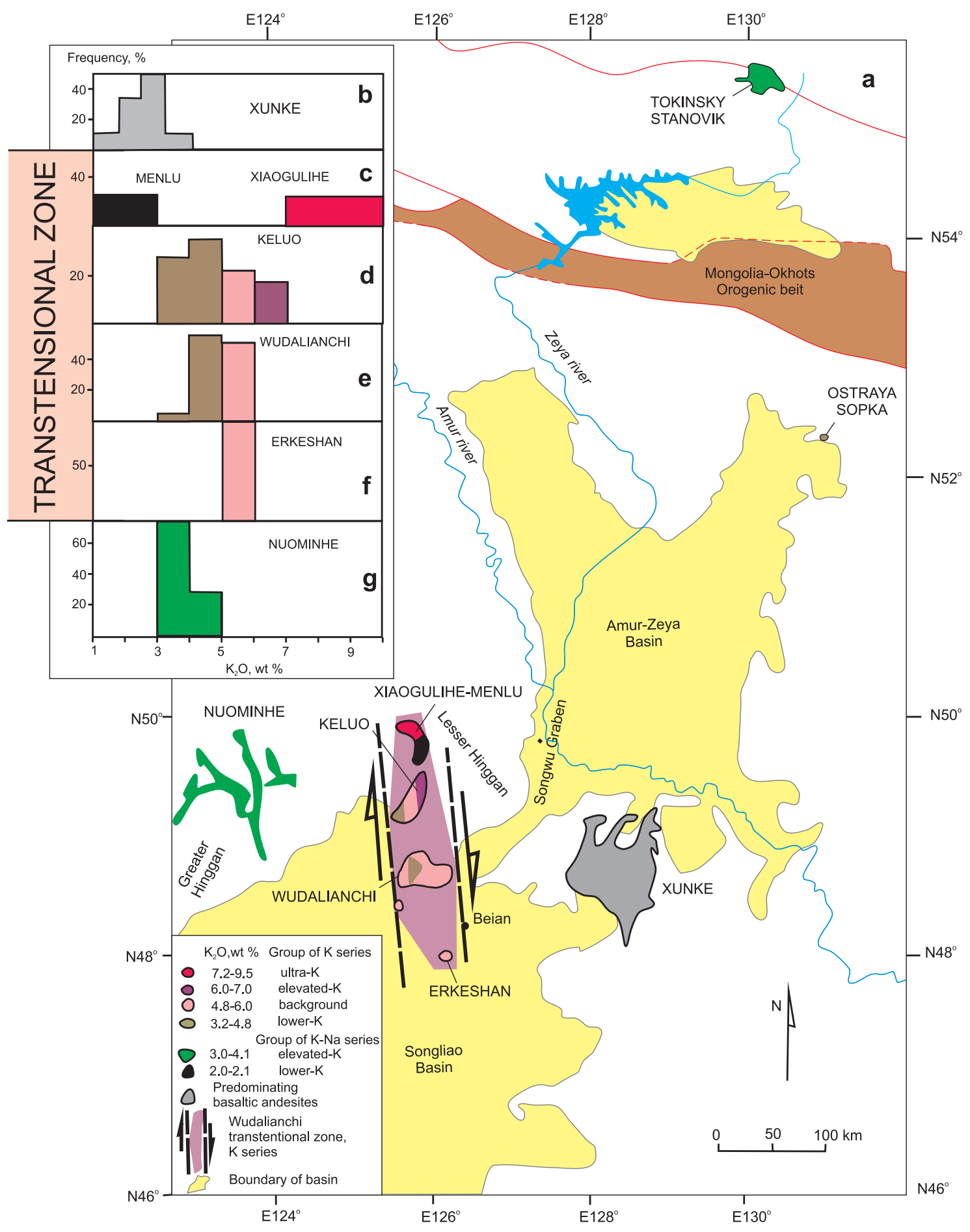

Fig. 2. Structural setting of the Pliocene-Quaternary volcanic fields with potassic, ultrapotassic, and potassic-sodic rocks between the Songliao and Amur-Zeya sedimentary basins.

Histograms $(b-g)$ demonstrate variations of $\mathrm{K}_{2} \mathrm{O}$ contents in lavas from different volcanic fields (explanations in the text). The colors of rock groups with different contents of potassium in the histograms match the coloring of the volcanic fields in the scheme $(a)$. Volcanic rocks of K series are located along the NS trending Wudalianchi zone and those of K-Na series along the WNW-ESE Nuominhe-Xunke zone. Data sources: Zhang et al., 1995; Liu et al., 2001; Wang, Chen, 2005; Chuvashova et al., 2009; Rasskazov et al., 2011 and unpublished data of the authors.

Рис. 2. Структурное положение плиоцен-четвертичных вулканических полей с калиевыми, ультракалиевыми и калинатровыми породами между осадочными бассейнами Сунляо и Амуро-Зейским.

Гистограммы $(b-g)$ демонстрируют вариации содержаний К을 в лавах из разных вулканических полей (объяснения в тексте). Цвета групп пород с разным содержанием калия на гистограммах соответствуют раскраске вулканических полей на схеме (a). Вулканические породы калиевой серии расположены вдоль субмеридиональной зоны Удаляньчи, калинатровой серии - вдоль зоны Нуоминхе-Сюнке с простиранием запад-северо-запад - восток-юго-восток. Источники данных: Zhang et al., 1995; Liu et al., 2001; Wang, Chen, 2005; Chuvashova et al., 2009; Rasskazov et al., 2011 и неопубликованные данные авторов. 


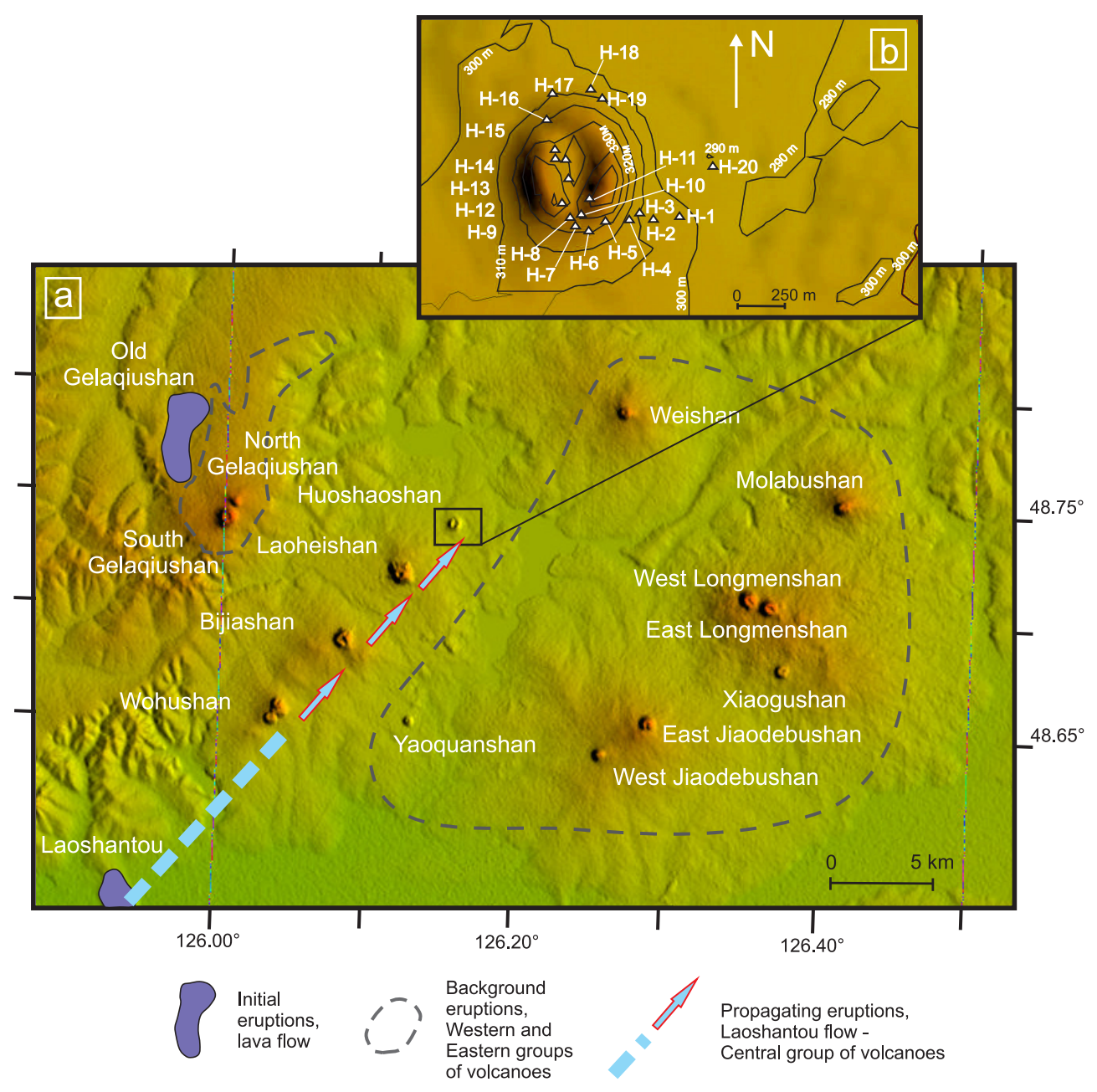

Fig. 3. Spatial distribution of volcanoes in the main Wudalianchi field (a), and sampling sites of the Huoshaoshan volcanic cone $(b)$.

Рис. 3. Пространственное распределение вулканов на основном поле Удаляньчи (a) и распределение образцов в опробовании конуса Хуошаошан $(b)$.

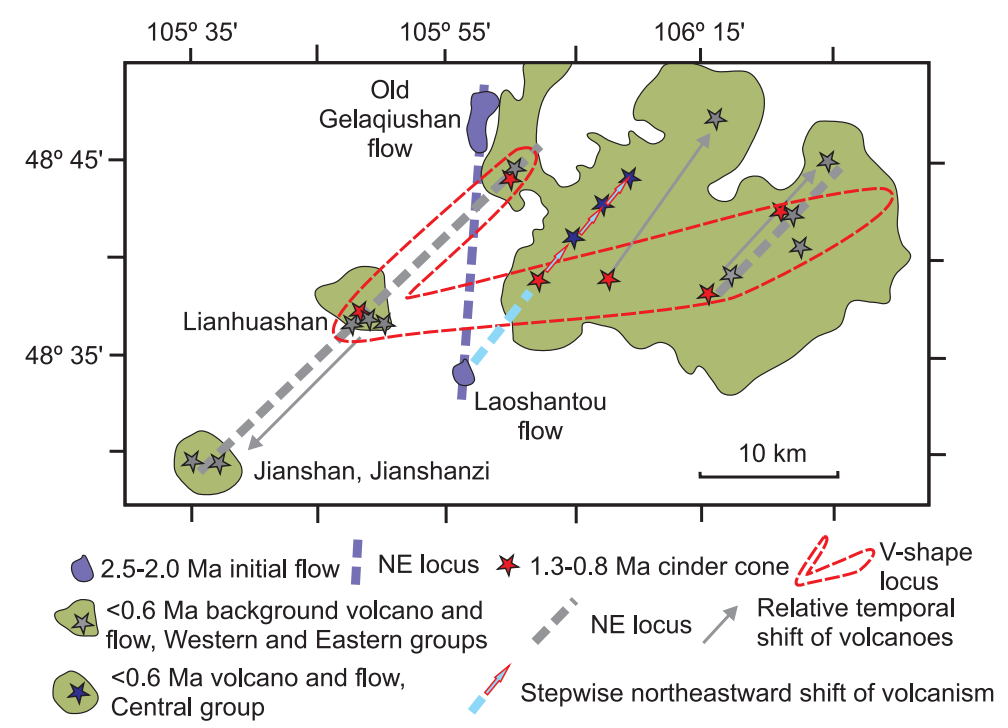

Fig. 4. Spatial-temporal distribution of volcanic eruptions of the main Wudalianchi volcanic field and satellite volcanic areas.

Рис. 4. Пространственно-временное распределение извержений на основном вулканическом поле Удаляньчи и сателлитных вулканических проявлениях. 


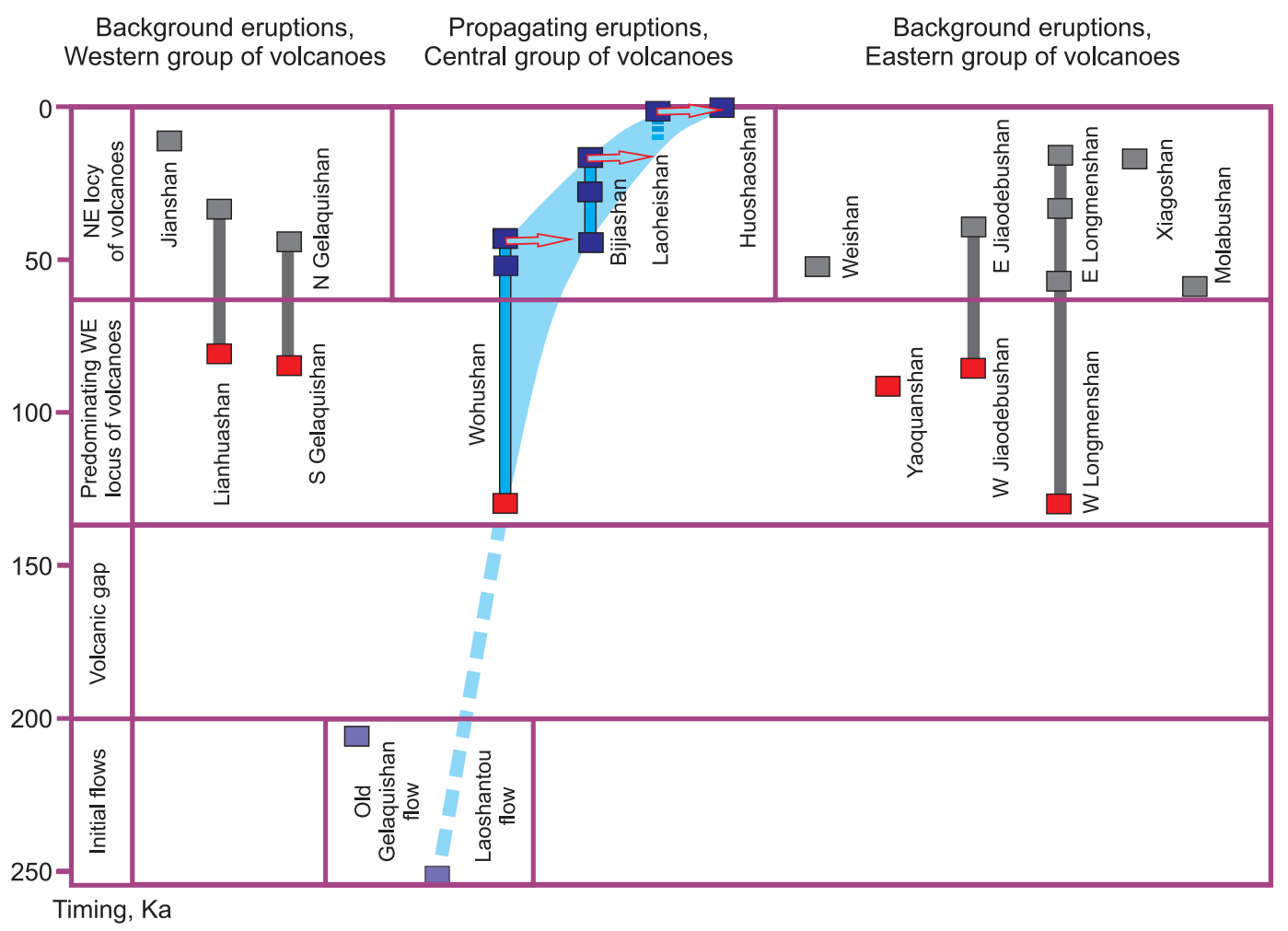

Fig. 5. Timing of activity in the Western, Central, and Eastern groups of volcanoes in the Wudalianchi field. The sequence of eruptions in the line of the Central group of volcanoes Wohushan-Huoshaoshan is marked by a blue colour. Arrows show jumps of volcanic eruptions. The scheme is modified after [Guide Book..., 2010] with additions (see text).

Рис. 5. Время активности Западной, Центральной и Восточной групп вулканов на поле Удаляньчи. Последовательность извержений в линии Центральной группы вулканов Уохушан-Хуошаошан выделена голубым цветом. Стрелки обозначают скачкообразное смещение извержений. Схема составлена по работе [Guide Book..., 2010] с дополнениями и изменениями (см. текст).

references to volcanoes without indications their exact locations. For example, major and trace-element contents for eight samples from the Laoheishan volcano were reported by Hsu and Chen [1998]. Phases of eruptions in this volcano were compositionally different, however. Without information on the locations, these data cannot be properly interpreted. $\mathrm{Sr}, \mathrm{Nd}$, and $\mathrm{Pb}$ isotopic ratios have more pronounced characteristics of rock groups than the major oxides or trace elements. These analytical results from [Zhang et al., 1995; Zou et al., 2003; Chu et al., 2013] are used here to extend the data sets for individual volcanoes (Table).

Wohushan - the first edifice in the sequence of volcanoes - was sampled in cones 1 and 2. Four samples of slag and porous basalts were selected from cone 1 (W-14-6-W-14-9) and five samples were taken from cone 2 (W-14-1 - W-14-5) (Fig. 6). The previously published composition of sample W1-32 from the volcano [Zhang et al., 1995] is similar to the one of rocks from cone 1.

Bijiashan - the second volcano in the sequence - is a vast lava shield crowned with a cinder cone. Samples Bd-14-1 and Bd-14-2 were taken from the lava pedes- tal of the volcano on its southern periphery. These rocks are compositionally comparable to sample B-1a [Zhang et al., 1995]. Samples Ch-07-31, Ch-07-32, and Ch-07-33 were selected from the southern and southeastern parts of the cinder cone and the adjacent lava flow.

Laoheishan - the third volcano in the sequence - revealed two phases of activity. An early pyroclastic cone (not sampled) was partially destroyed by the explosion that created a somma-crater occupied by a new pyroclastic cone with a new crater (Fig. 7). Agglutinate and vesicular glassy basalt samples Lo-11-5 - Lo-11-7 were taken from the late cone. Compositionally, these rocks are similar to lava samples Lo-11-11, Lo-11-12, Lao-09 that were picked up from the northern bocca of the edifice. This group is comparable to samples A-2 [Zhang et al., 1995], LE 6-4, and LHK-1 [Zou et al., 2003]. Volcanic bomb sample Lo-11-8, taken from pyroclastic debris deposited on the southwestern edge of the late crater, is compositionally similar to samples A-65 [Zhang et al., 1995] and LW5-2 [Zou et al., 2003]. Other samples related to the final crater of the edifice show a compact group of compositions: a piece of black glass from the 


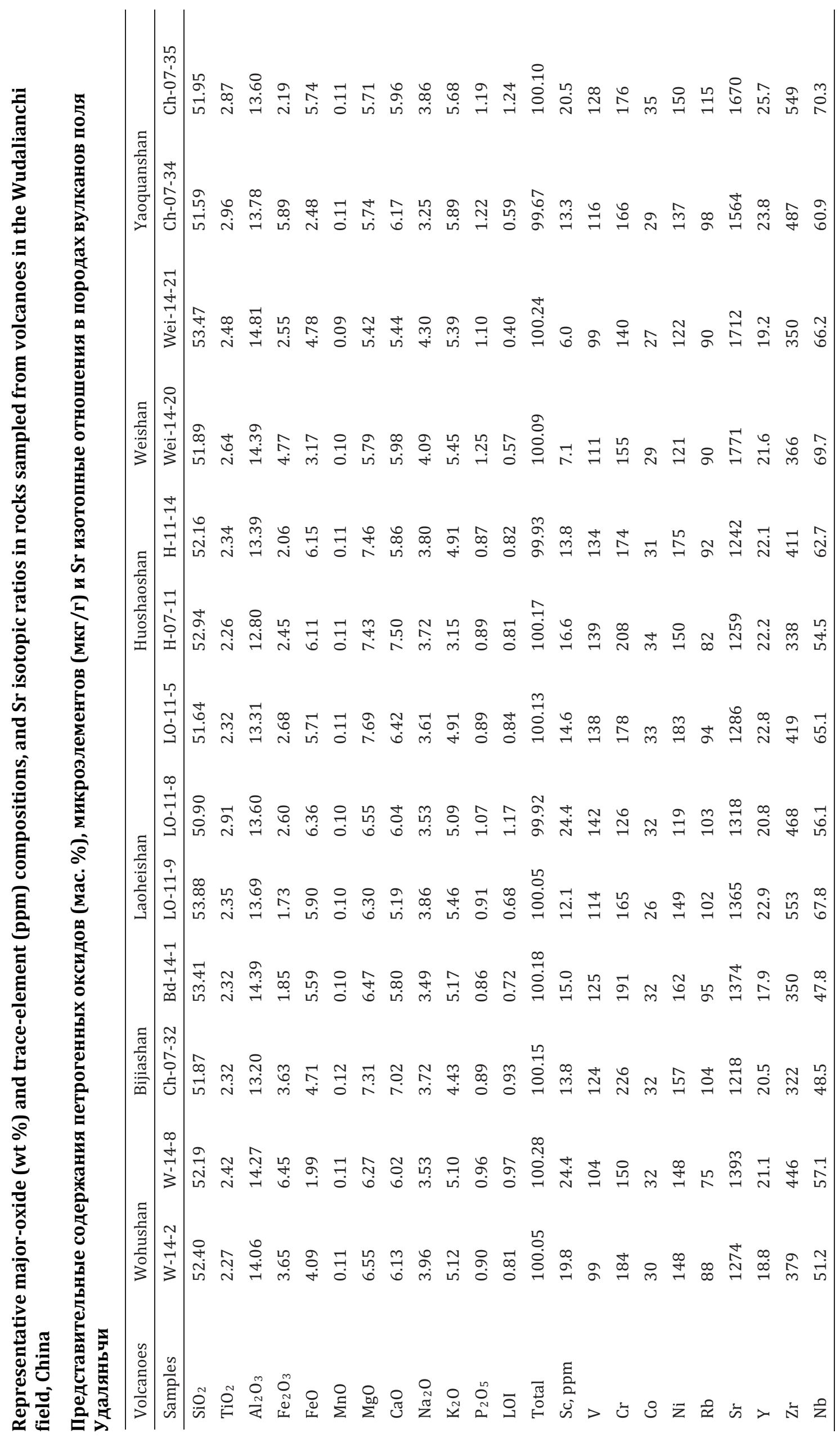




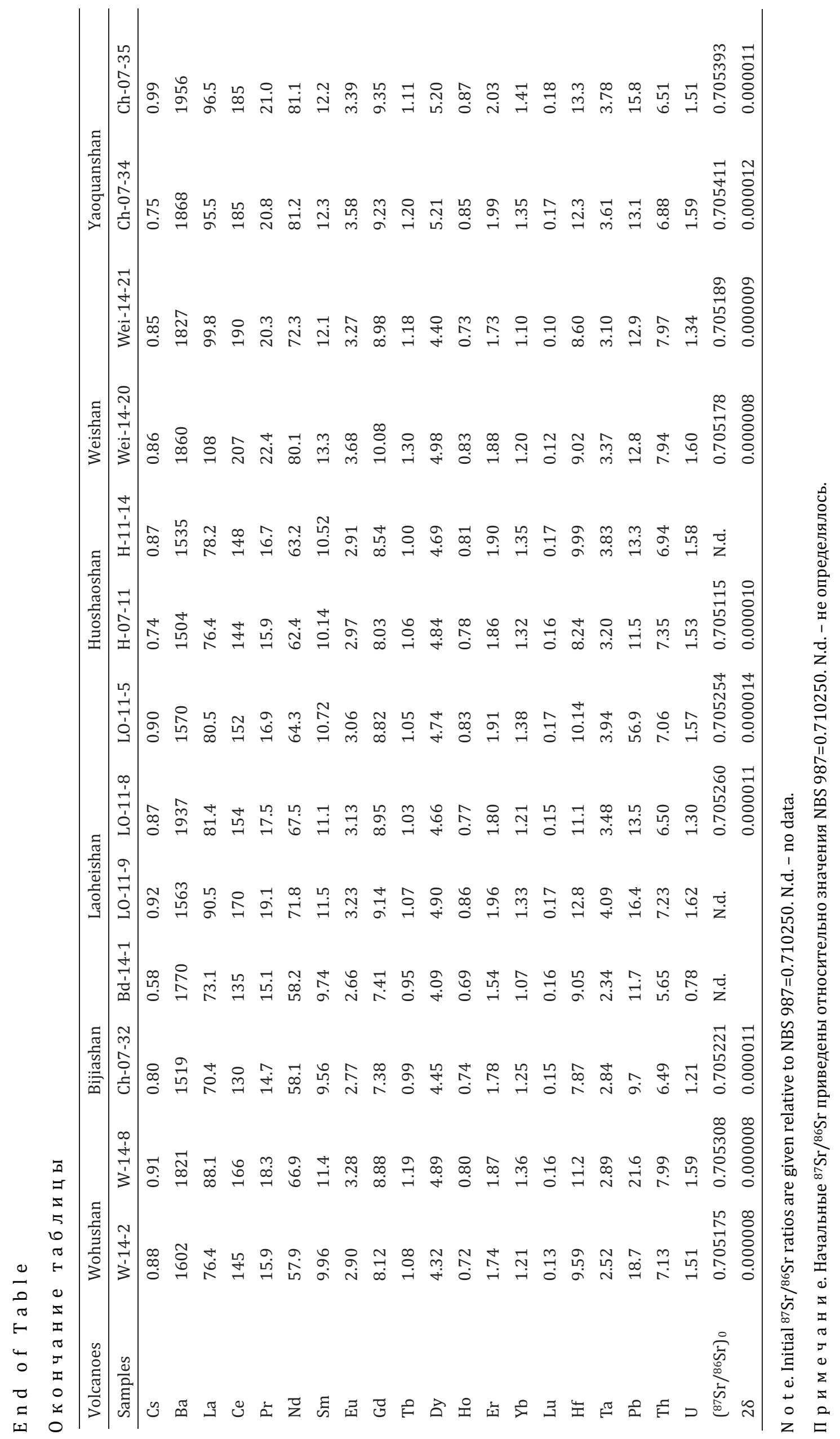




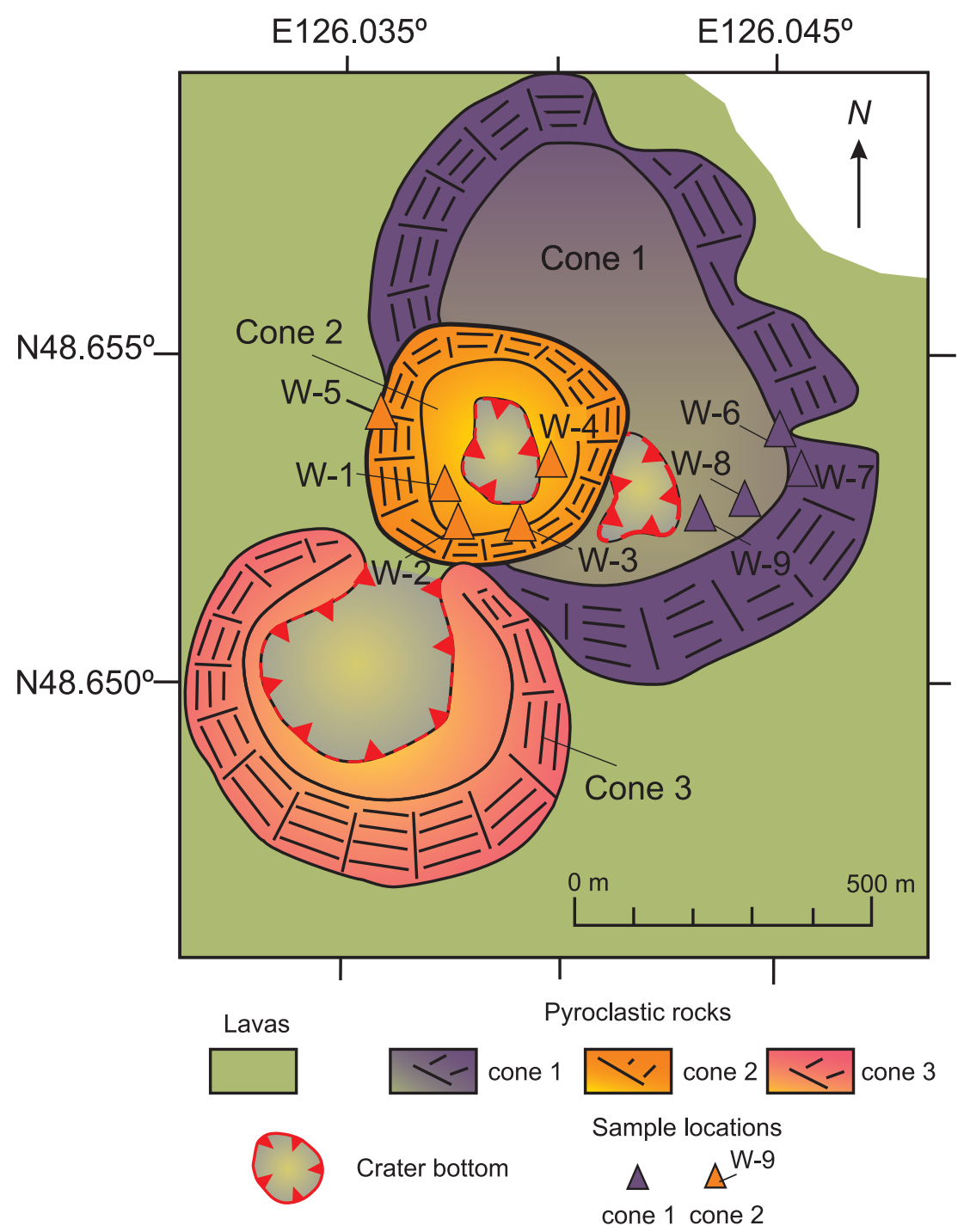

Fig. 6. A sketch-map of the Wohushan volcano showing sampling sites. For simplification, index "14" is skipped in the sample numbers shown in the figures (W-1 means $\mathrm{W}-14-1$ etc.).

Рис. 6. Точки отбора образцов на схематической карте вулкана Уохушан. Для упрощения номера образцов приведены без «14» (W-1 вместо W-14-1 и т.д.).

northwestern edge of the crater (Lo-11-9, Lo-11-10), red slag, lapilli and bombs $1.2 \mathrm{~km}$ to the south of the crater (samples Lo-11-13A, B, C). Similar compositions were reported for samples L-13, A-4 [Zhang et al., 1995], LS3-1, HL9720, and NDW2-2b [Zou et al., 2003].

Huoshaoshan - the fourth volcano in the sequence unlike other edifices, is composed of porous basalts that formed a volcanic cone and surrounding lava flows. Samples H-07-1 - H-07-20 were taken from the cone and adjacent lava flow (Fig. 3, b). Sample H-11-14 was picked up from a flow at a distance of $1 \mathrm{~km}$ south of the cone, and sample Lo-11-15 at a distance of $2 \mathrm{~km}$ east-northeast of it (in the garnito site). The previously published compositions of rocks from the cone of this volcano were: H-38 [Zhang et al., 1995], HS2-2, HK-2, HN6-1 [Zou et al., 2003]. Samples HSS2, HSS5 were taken from a flow to the northeast of the cone, and samples HSS6, HSS8 from a flow to the east of it [Chu et al., 2013].

\section{SILICA AND ALKALIS OXIDES}

On the total alkalis-silica (TAS) diagram (Fig. 8, a), data points of background rocks are distributed along the dividing lines between highly and moderately alkaline series mainly in tephriphonolite and trachyandesite fields with minor samples in the phonotephrite field. Background rocks from some volcanoes (e.g. Yaoquanshan and Weishan) are highly alkaline (phonotephrites and tephriphonolites). Background rocks from other volcanoes (Longmenshan, Jiaodebushan 

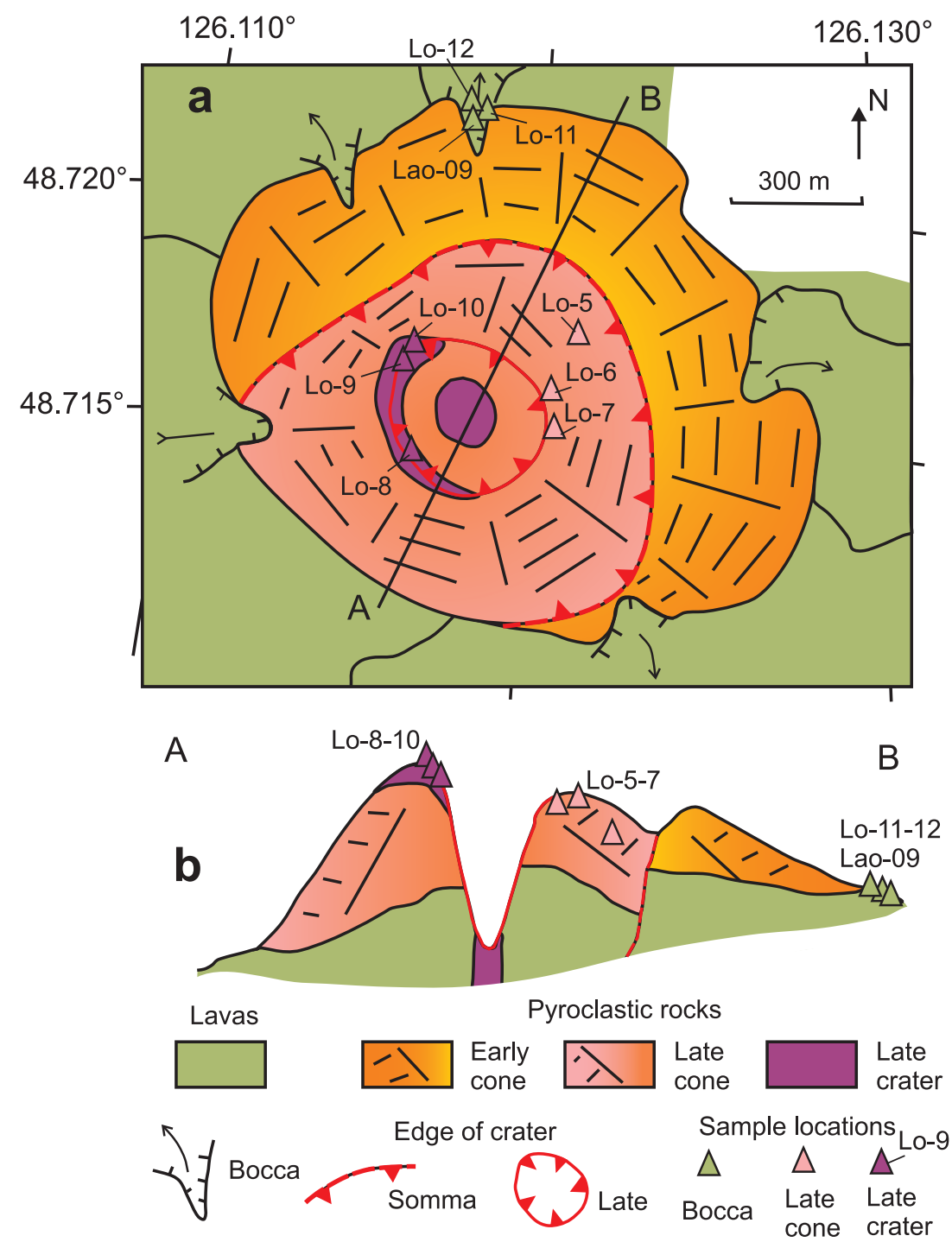

Fig. 7. Locations of samples on a sketch-map $(a)$ and cross-section $\mathrm{AB}(b)$ of the Laoheishan volcano. Scheme of the edifice is modified after [Xiao, Wang, 2009; Guide Book..., 2010].

Рис. 7. Местоположение образцов на карте-схеме $(a)$ и разрезе АВ $(b)$ вулкана Лаохейшан. Схема постройки [Хіaо, Wang, 2009; Guide Book..., 2010] с уточнениями.

etc.) are moderately alkaline (mostly trachyandesites). In background rocks, $\mathrm{Na}_{2} \mathrm{O}+\mathrm{K}_{2} \mathrm{O}$ range from 8.6 to 9.7 wt \%, $\mathrm{SiO}_{2}$ from 51.6 to 55.0 wt \%. Phonotephrites from the Erkeshan field are comparable with the $\mathrm{Wu}$ dalianchi background rocks of this type (Table).

Data points of rocks from the Central group of volcanoes are also distributed along the discriminating line of highly and moderately alkaline series, mainly in the phonotephrite and trachyandesite fields. Almost all samples from the first volcano (Wohushan) fall within the data field of background rocks. Rock compositions of the second and third volcanoes (Bijiashan and Laoheishan) changed on each of them from similar to the background to the ones distinguished by the lower silica and alkalis contents. On the Bijiashan volcano, eruptions were exhibited by trachyandesites of a lava shield and by basaltic trachyandesites and phonotephrites of a volcanic cone. The trachyandesites were comparable to the background rocks, the basaltic trachyandesites and phonotephrites differed from them. On the Laoheishan volcano, rocks of the second phase of eruption were subdivided into three groups: (1) basaltic trachyandesites and phonotephrites, (2) trachyandesites, and (3) phonotephrites. The first group was recorded in pyroclastic material from the late volcanic cone and lavas from the northern bocca, the second group in pyroclastic material from the northwestern edge of the late crater, and the third group in bombs from its southwestern edge.

On the fourth volcano (Huoshaoshan), rocks are basaltic trachyandesites and phonotephrites. In the peripheral parts of the lava fan, samples HUO-11-11 and 


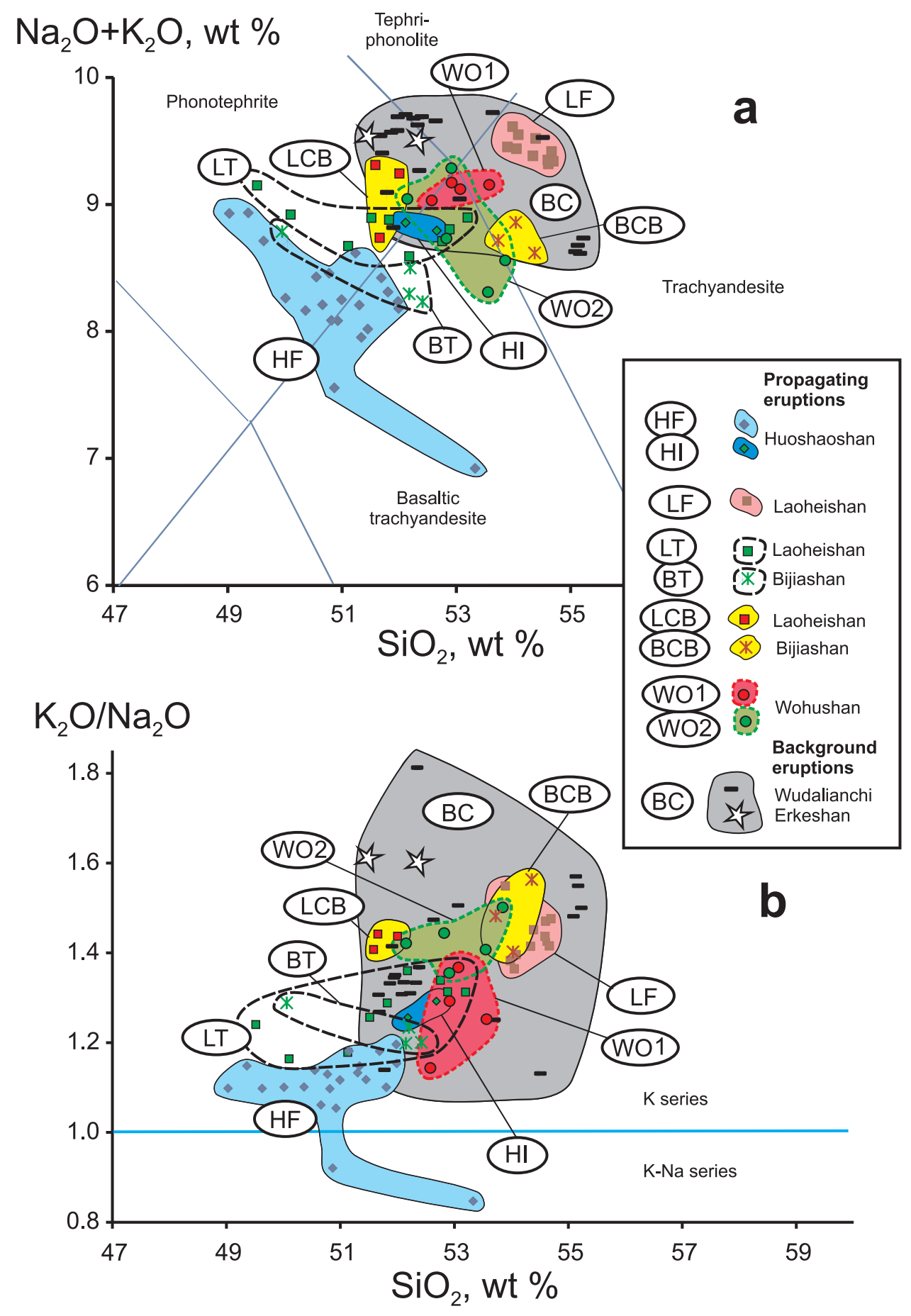

Fig. 8. Diagrams $\mathrm{Na}_{2} \mathrm{O}+\mathrm{K}_{2} \mathrm{O}$ vs. $\mathrm{SiO}_{2}(a)$ and $\mathrm{K}_{2} \mathrm{O} / \mathrm{Na}_{2} \mathrm{O}$ vs. $\mathrm{K}_{2} \mathrm{O}(b)$ for volcanic rocks.

Symbols in the ellipses: BC - background compositions; W01, WO2 - compositions of pyroclastic rocks from cones 1 and 2 of the Wohushan volcano; BCB, LCB - close to background compositions in the Bijiashan peripheral flows and bombs of the late Laoheishan volcanic crater (eruption phase 2); BT, LT - transitional compositions in the cone of the Bijiashan volcano and in the Laoheishan volcano (eruption phase 2); LF - final pyroclastic material related to the late crater of the Laoheishan volcano (eruption phase 2); HI - Huoshaoshan initial compositions of peripheral lava flows; HF - Huoshaoshan final compositions of the cone. Analyses are recalculated to $100 \%$ without loss on ignition.

Рис. 8. Диаграммы $\mathrm{Na}_{2} \mathrm{O}+\mathrm{K}_{2} \mathrm{O}-\mathrm{SiO}_{2}(a)$ и $\mathrm{K}_{2} \mathrm{O} / \mathrm{Na}_{2} \mathrm{O}-\mathrm{SiO}_{2}(b)$ вулканических пород.

Обозначения в эллипсах: BC (background compositions) - фоновые составы; WO1, WO2 - составы пирокластических пород конусов 1 и 2 вулкана Уохушан; BCB, LCB (Bijiashan, Laoheishan close to background) - близкие к фоновым составы периферийного потока вулкана Бидзиашан и бомб позднего кратера вулкана Лаохейшан (вторая фаза извержений); BT, LT (transitional) - переходные составы на конусе вулкана Бидзиашан и на вулкане Лаохейшан (вторая фаза извержений); LF (Laoheishan final) - cocтавы пирокластических пород позднего кратера вулкана Лаохейшан (вторая фаза извержений); HI (Huoshaoshan initial) - начальные составы периферических лавовых потоков вулкана Хуошаошан; HF (Huoshaoshan final) финальные составы извержений конуса этого же вулкана. Анализы приведены к 100 \% с исключением из суммы потерь при прокаливании. 


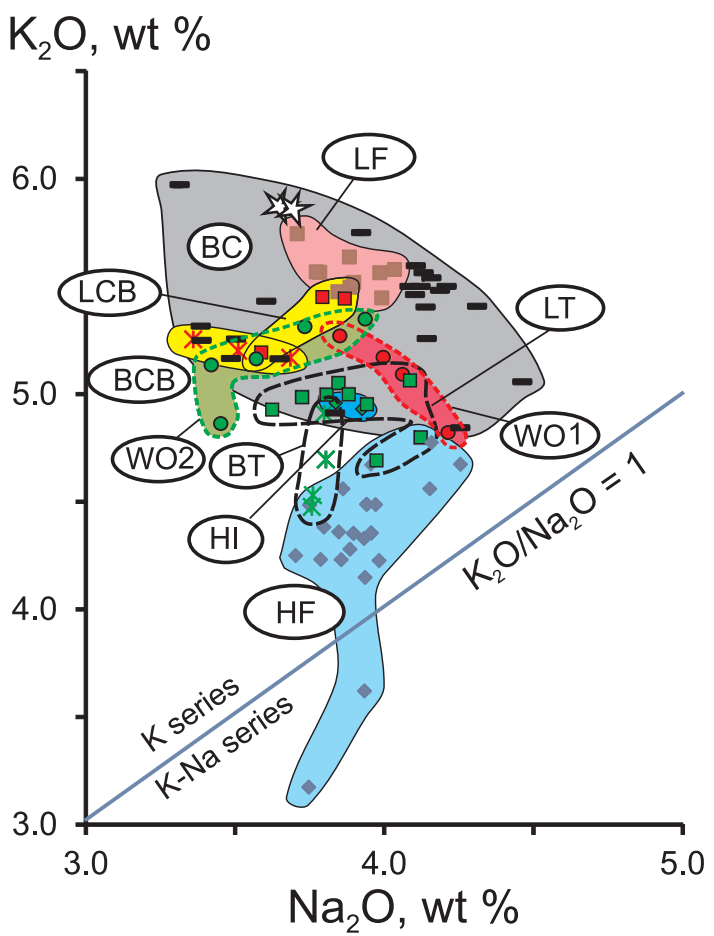

Fig. 9. The diagram of $\mathrm{K}_{2} \mathrm{O}$ vs. $\mathrm{Na}_{2} \mathrm{O}$ for volcanic rocks. The symbols are given in Fig. 8.

Рис. 9. Диаграмма $\mathrm{K}_{2} \mathrm{O}-\mathrm{Na}_{2} \mathrm{O}$ вулканических пород. Условные обозначения см. на рис. 8.

HUO-11-14 overlap with the background rocks under the elevated silica and alkalis contents (about 52-53 and 9 wt \%, respectively). The rocks of the cone considerably differ from the background rocks. The phonotephrites show a decreasing $\mathrm{SiO}_{2}$ content to $49 \mathrm{wt} \%$ at the alkalis content about 9 wt \%. The trachyandesites demonstrate a decreasing alkalis content to 7 wt $\%$ at $\mathrm{SiO}_{2}$ content about 53 wt \%.

In background rocks, $\mathrm{K}_{2} \mathrm{O} / \mathrm{Na}_{2} \mathrm{O}$ vary from 1.1 to 1.8 (Fig. 8, b). Rocks from the Wohushan, Bijiashan, and Laoheishan volcanoes have comparable ratios. Flows of peripheral parts of the lava fan in the Huoshaoshan volcano have elevated $\mathrm{K}_{2} \mathrm{O} / \mathrm{Na}_{2} \mathrm{O}$ ratios (1.26-1.29) within the ratio range of background rocks. The rocks from the Huoshaoshan volcanic cone display a trend to the $\mathrm{K}_{2} \mathrm{O} / \mathrm{Na}_{2} \mathrm{O}$ interval of $0.82-1.20$ with transition from potassic to potassic-sodic series.

Background rocks show $\mathrm{K}_{2} \mathrm{O}$ and $\mathrm{Na}_{2} \mathrm{O}$ contents in the ranges of 4.8-6.0 and 3.3-4.5 wt \%, respectively (Fig. 9). Among rocks from the Central group of volcanoes, the $\mathrm{K}_{2} \mathrm{O}$ contents decrease from the near background values in rocks from the Bijiashan and Laoheishan volcanoes through concentrations in the Wohushan rocks, transitional compositions in the Bijiashan and Laoheishan volcanoes together with peripheral lavas from the Huoshaoshan volcano to the final compositions of the Huoshaoshan volcanic cone. The final trachyandesite pyroclastics of the Laoheishan volcano reveals the $\mathrm{K}_{2} \mathrm{O}$ contents as high as 5.5-5.8 wt \% (i.e. within the background level), whereas the initial Laoshantou flow shows the $\mathrm{K}_{2} \mathrm{O}$ content as low as 4 wt \% [Zhao et al., 2014].

We infer that, in terms of $\mathrm{Na}_{2} \mathrm{O}, \mathrm{K}_{2} \mathrm{O}$, and $\mathrm{SiO}_{2}$ contents, peripheral lavas of volcanic fans in the Bijiashan, Laoheishan, and Huoshaoshan volcanoes were close to background rocks. The contents of these major oxides differ from the background signatures and characterize rocks from volcanic cones in a linear progression that demonstrates the transition from compositions of the Wohushan volcano, close to the background ones, through the intermediate values in the Bijiashan and Laoheishan volcanoes to the final compositions in the Huoshaoshan volcanic cone.

\section{OTHER MAJOR OXIDES}

Changes of rock compositions along the WohushanHuoshaoshan line from the close to background signatures at the first volcano (Wohushan) through the contrast major oxide contents at the Bijiashan and Laoheishan edifices to notably different from the background ones at the Huoshaoshan cone are illustrated further by diagrams of $\mathrm{SiO}_{2}$ vs. $\mathrm{MgO}, \mathrm{Al}_{2} \mathrm{O}_{3}$ vs. $\mathrm{MgO}, \mathrm{CaO}$ vs. $\mathrm{MgO}$, and $\mathrm{P}_{2} \mathrm{O}_{5}$ vs. $\mathrm{MgO}$ (Figs 10,11).

The $\mathrm{MgO}$ contents of the background rocks vary from 5.4 to $7.0 \mathrm{wt} \%$. As contents of this oxide increase to $8.2 \mathrm{wt} \%$, the transitional compositions of the $\mathrm{Bi}$ jiashan and Laoheishan volcanoes, initial and final compositions of the Huoshaoshan volcano show decreasing $\mathrm{Al}_{2} \mathrm{O}_{3}$ concentrations up to $12 \mathrm{wt} \%$ with increasing $\mathrm{CaO}$ to 8 wt \%. The $\mathrm{SiO}_{2}$ and $\mathrm{Al}_{2} \mathrm{O}_{3}$ contents of the transitional groups of rocks overlap with both the initial and final compositions of rocks from the Huoshaoshan volcano, unlike the $\mathrm{CaO}$ contents that differ from the final compositions. The transitional compositions reveal $\mathrm{CaO}$ scattering between 6 and $8 \mathrm{wt} \%$. In the initial lavas from the Huoshaoshan volcano, the $\mathrm{CaO}$ contents coincide with the lowest values of this interval, while the contents in the final lavas of the volcano have a narrow range of 7-8 wt \%. At maximal concentrations of $\mathrm{CaO}$ and $\mathrm{MgO}$, trends of transitional compositions in the Laoheishan volcano and final compositions in the Huoshaoshan volcano intersect.

Plots of $\mathrm{SiO}_{2}$ vs. $\mathrm{MgO}$ and $\mathrm{Al}_{2} \mathrm{O}_{3}$ vs. $\mathrm{MgO}$ emphasize similarities of rock compositions from the Wohushan volcano and low-Mg groups of rocks from the Bijiashan and Laoheishan volcanoes to background compositions and their differences to compositions of the transitional groups with elevated $\mathrm{MgO}$ contents from these volcanoes. The diagram of $\mathrm{CaO}$ vs. $\mathrm{MgO}$ demonstrates $\mathrm{CaO}$ scattering of background rocks from 5 to $6 \mathrm{wt} \%$. The $\mathrm{CaO}$ contents in the final pyroclastic material from the 

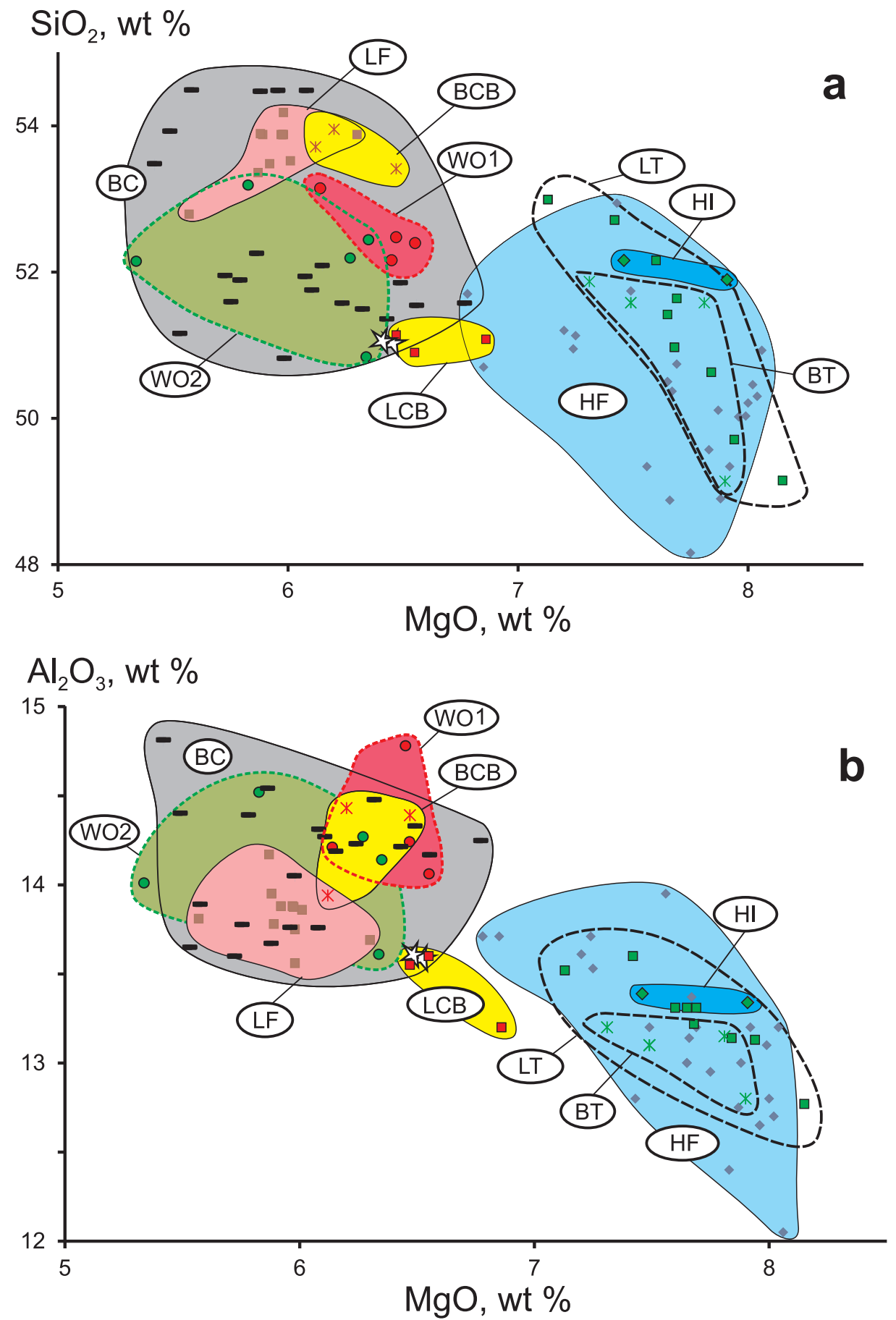

Fig. 10. Diagrams of $\mathrm{SiO}_{2}$ vs. $\mathrm{MgO}(a)$ and $\mathrm{Al}_{2} \mathrm{O}_{3}$ vs. $\mathrm{MgO}(b)$ for volcanic rocks. The symbols are given in Fig. 8.

Рис. 10. Диаграммы $\mathrm{SiO}_{2}-\mathrm{MgO}(a)$ и $\mathrm{Al}_{2} \mathrm{O}_{3}-\mathrm{MgO}(b)$ вулканических пород. Условные обозначения см. на рис. 8.

Laoheishan volcano correspond to the lower values of this range (5.0-5.4 wt \%), while the contents in the Huoshaoshan rocks and compositionally similar Bijiashan and Laoheishan rocks rise to the range of 5.9-6.6 wt $\%$.

A plot of $\mathrm{P}_{2} \mathrm{O}_{5}$ vs. $\mathrm{MgO}$ (Fig. $11, b$ ) reveals a wide range of $\mathrm{P}_{2} \mathrm{O}_{5}$ concentrations in the background rocks (0.9-1.3 wt \%). Concentrations of this oxide as low as 0.90-0.95 wt \% are characteristic of rocks with a limi- ted range of $\mathrm{MgO}$ contents, 5.4-6.1 wt \%. The elevated values between 1.2 and $1.3 \mathrm{wt} \%$ are observed in rocks with the full range of $\mathrm{MgO}$, 5.5-6.8 wt \%. Rocks from the Central group of volcanoes reveal opposite $\mathrm{P}_{2} \mathrm{O}_{5}$ trends for the low- and moderate-Mg compositions. The lower $\mathrm{P}_{2} \mathrm{O}_{5}$ concentrations of $0.85-1.00$ wt $\%$ are defined for the full $\mathrm{MgO}$ ranges of 5.3-6.6 and 6.8-8.1 wt $\%$, the elevated ones of $1.02-1.21 \mathrm{wt} \%$ are limited to the MgO ranges of 7.6-8.2 and 5.5-6.8 wt \%. Data 


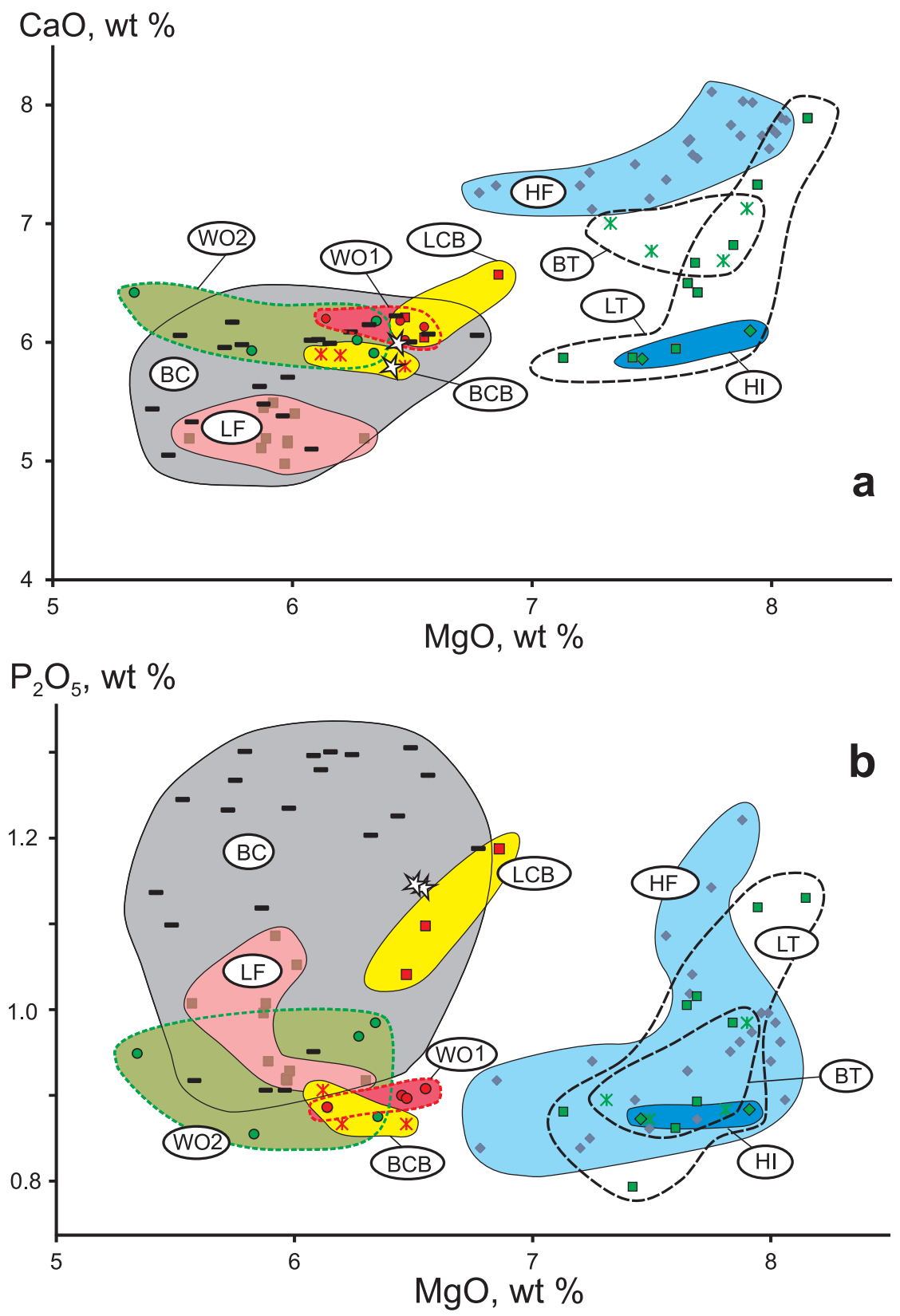

Fig. 11. Diagrams of $\mathrm{CaO}$ vs. $\mathrm{MgO}(a)$ and $\mathrm{P}_{2} \mathrm{O}_{5}$ vs. $\mathrm{MgO}(b)$ for volcanic rocks. The symbols are given in Fig. 8.

| Рис. 11. Диаграммы $\mathrm{CaO}$ - $\mathrm{MgO}(a)$ и $\mathrm{P}_{2} \mathrm{O}_{5}-\mathrm{MgO}(b)$ вулканических пород. Условные обозначения см. на рис. 8.

points of the final pyroclastics from the late crater of the Laoheishan volcano show $\mathrm{P}_{2} \mathrm{O}_{5}$ concentrations of 0.9-1.1 wt \% within the background range. On the diagrams of $\mathrm{CaO}$ vs. $\mathrm{MgO}$ and $\mathrm{P}_{2} \mathrm{O}_{5}$ vs. $\mathrm{MgO}$, data points of the final pyroclastic material from the Laoheishan volcano occupy the lower parts of the data fields for the background rocks.

\section{TRACE ELEMENTS}

Background rocks show relatively low concentrations of compatible trace elements $\mathrm{Ni}$ and $\mathrm{Cr}$ (respec- tively, 120-156 and 120-180 ppm). In rocks from the Central group of volcanoes, which overlap with the background ones in terms of $\mathrm{MgO}$ contents, concentrations of $\mathrm{Ni}$ and $\mathrm{Cr}$ vary within the same ranges and partially exceed the background concentrations. In the moderate-Mg transitional rocks from the Bijiashan and Laoheishan volcanoes, $\mathrm{Ni}$ contents increase to a range of $160-220 \mathrm{ppm}$ and $\mathrm{Cr}$ contents to a range of 150-280 ppm. The $\mathrm{Ni}$ and $\mathrm{Cr}$ concentrations for peripheral flows of the initial Huoshaoshan eruptions fall in these intervals, but $\mathrm{Ni}$ and $\mathrm{Cr}$ contents for the final cone of the volcano differ markedly. As MgO decreases, $\mathrm{Ni}$ and $\mathrm{Cr}$ contents in these Huoshaoshan rocks 

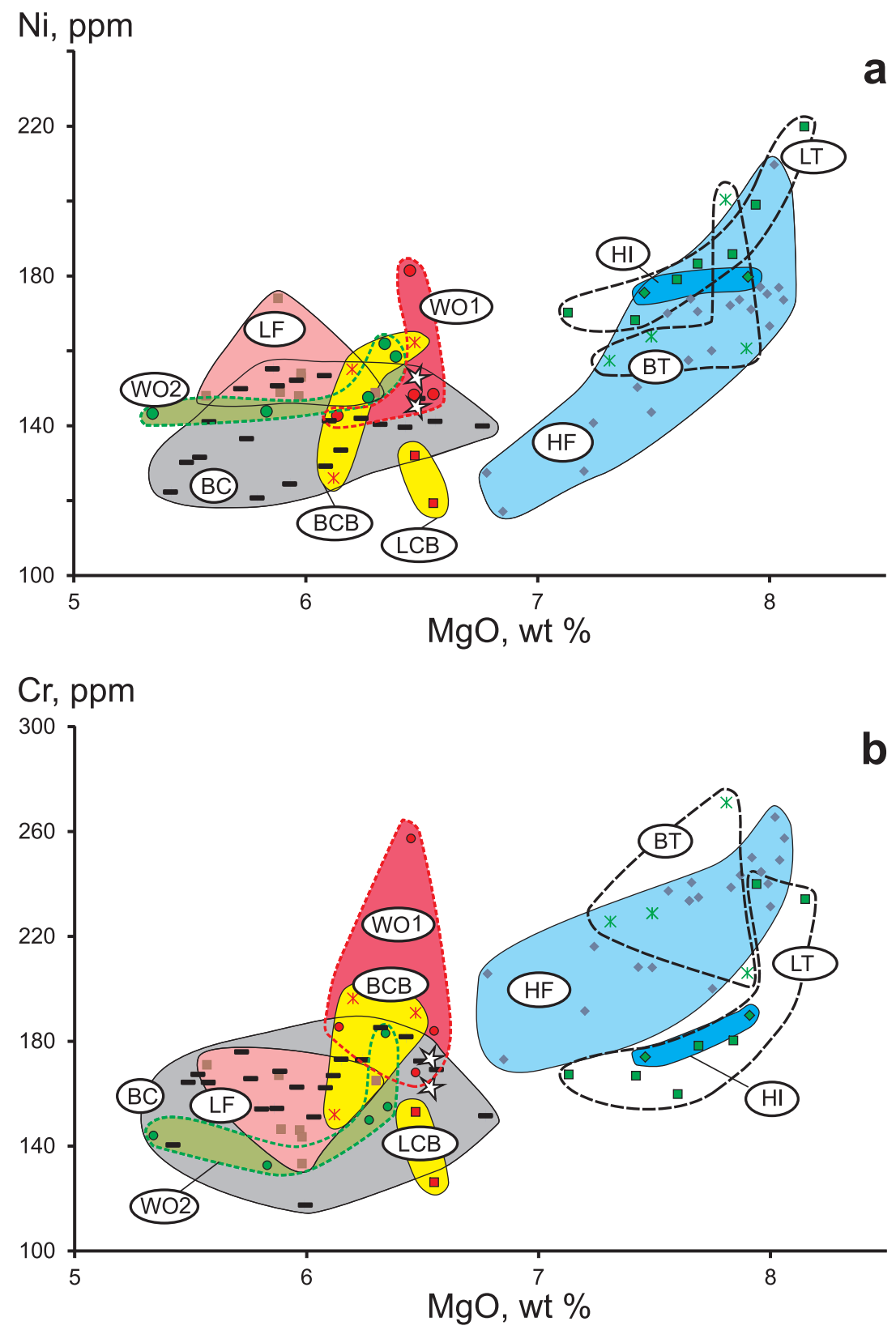

Fig. 12. Diagrams of Ni vs. $\mathrm{MgO}(a)$ and $\mathrm{Cr}$ vs. $\mathrm{MgO}(b)$ for volcanic rocks. The symbols are given in Fig. 8.

| Рис. 12. Диаграммы $\mathrm{Ni}-\mathrm{MgO}(a)$ и $\mathrm{Cr}-\mathrm{MgO}(b)$ вулканических пород. Условные обозначения см. на рис. 8.

decrease, respectively, from 210 to $120 \mathrm{ppm}$ and from 260 to $180 \mathrm{ppm}$. The start of the downward trend coincides with the $\mathrm{Ni}$ data field of transitional rocks from the Bijiashan and Laoheishan volcanoes. The reduction trend of $\mathrm{Cr}$ concentrations in rocks from the Huoshaoshan volcano coincides with the data field of transitional rocks from the Bijiashan volcano and with a start of a trend of transitional rocks from the Laoheishan volcano. In transitional rocks from the Laoheishan volcano and peripheral lava flows of the Huoshaoshan volcano, $\mathrm{Cr}$ concentrations are relatively low (Fig. 12).

In diagrams of trace elements, normalized to the primitive mantle composition, rocks from the Central volcanic group demonstrate uniform spectra, as it was shown by previous studies [Hsu, Chen, 1998; Chu et al., 2013]. The presented patterns for volcanic rocks from the Wohushan and Huoshaoshan volcanoes show $\mathrm{Ba}, \mathrm{K}$, $\mathrm{La}$, and $\mathrm{Pb}$ peaks, $\mathrm{Th}-\mathrm{U}, \mathrm{Nb}-\mathrm{Ta}$, and Ce troughs, and no significant anomalies from Pr to Yb (Fig. 13).

No significant differences are found also in terms of rare earth elements between the rocks from the Central volcanic group. Nevertheless, their specific features, similar to the background signatures and different from them, are emphasized on plots of $\mathrm{Rb} v \mathrm{vs}$. $\mathrm{MgO}, \mathrm{Zr}$ vs. MgO, Ba vs. MgO, Th vs. MgO, Sr vs. $\mathrm{MgO}$, and $\mathrm{La} / \mathrm{Yb}$ vs. MgO (Figs 14, 15). A similar behavior is 


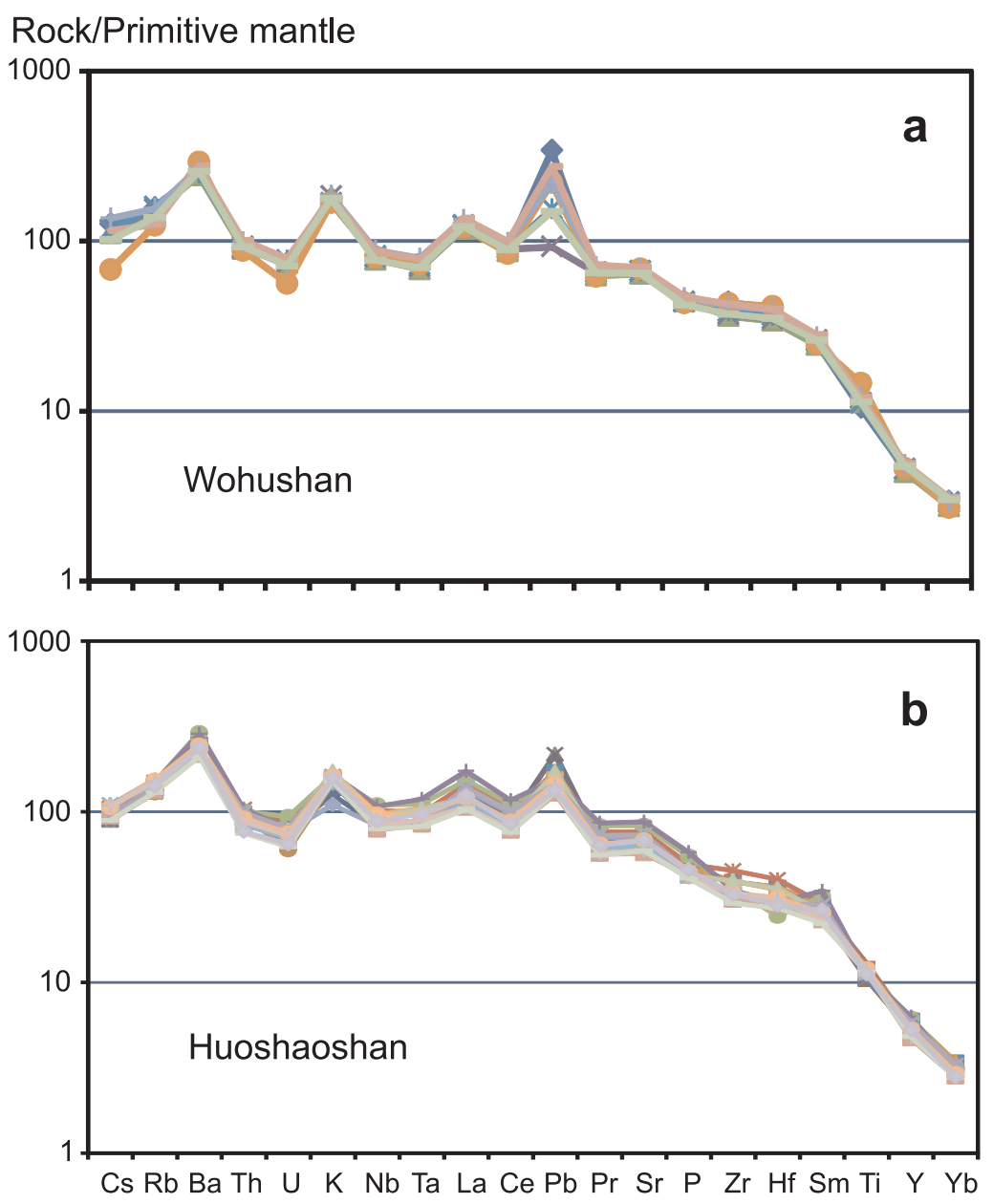

Fig. 13. Primitive mantle-normalized trace-element patterns for rocks from the Wohushan $(a)$ and Huoshaoshan $(b)$ volcanoes. Normalizing values after [McDonough, Sun, 1995].

Рис. 13. Сопоставление спектров несовместимых элементов, нормированных к примитивной мантии, для пород вулканов Уохушан (a) и Хуошаошан $(b)$. Для нормирования использован состав [McDonough, Sun, 1995].

shown, on the one hand, for $\mathrm{Rb}$ and $\mathrm{Zr}$, and on the other hand, for $\mathrm{Ba}, \mathrm{Th}, \mathrm{Sr}$, and $\mathrm{La} / \mathrm{Yb}$.

In rocks from the Central group of volcanoes, which are compositionally close to the background ones, $\mathrm{Rb}$ concentrations increase from the first volcano (Wohushan) through the second (Bijiashan) to the third (Laoheishan). In rocks, which differ from the background ones, $\mathrm{Rb}$ concentrations increase from the second to the fourth volcano and decrease in its final edifice (Fig. 14, a). In rocks close to the background ones, $\mathrm{Zr}$ concentrations decrease from the first to the second volcano and increase to the third volcano. In rocks distinguished from background ones, relatively low concentrations of $\mathrm{Zr}$ at the first volcano change to elevated concentrations at the third and fourth volcanoes with a relative decrease at the final Huoshaoshan edifice (Fig. 14, b). While analyzing similar behavior of $\mathrm{Rb}$ and $\mathrm{Zr}$, one can notice anomalously low concentrations of the latter element in rocks from the second volcano (Bijiashan).
On diagrams of $\mathrm{Ba}$ vs. $\mathrm{MgO}$ and Th vs. $\mathrm{MgO}$ (Fig. 15, $a, b$ ), data fields of low-Mg volcanic rocks from the Central volcanic group are distributed randomly within the data field of the background rocks. Meanwhile, moderate-Mg rocks (distinguished from background ones) show repeated configurations of data fields. Similarly, rock compositions vary in plots of $\mathrm{Sr}$ vs. $\mathrm{MgO}$ and La/Yb vs. Mg0 (Fig. 16, $a, b$ ).

\section{DISCUSSION}

When interpreting the potassic volcanism as a derivative of mainly lithospheric sources, we rely on its distinct dependence on the lithosphere structure formed during the subsidence of the Songliao basin, and suggest that spatial-temporal distribution of volcanic activity and rock compositional variations are controlled by transtension developed along the Wudalianchi zone. While searching for regularities of magma 

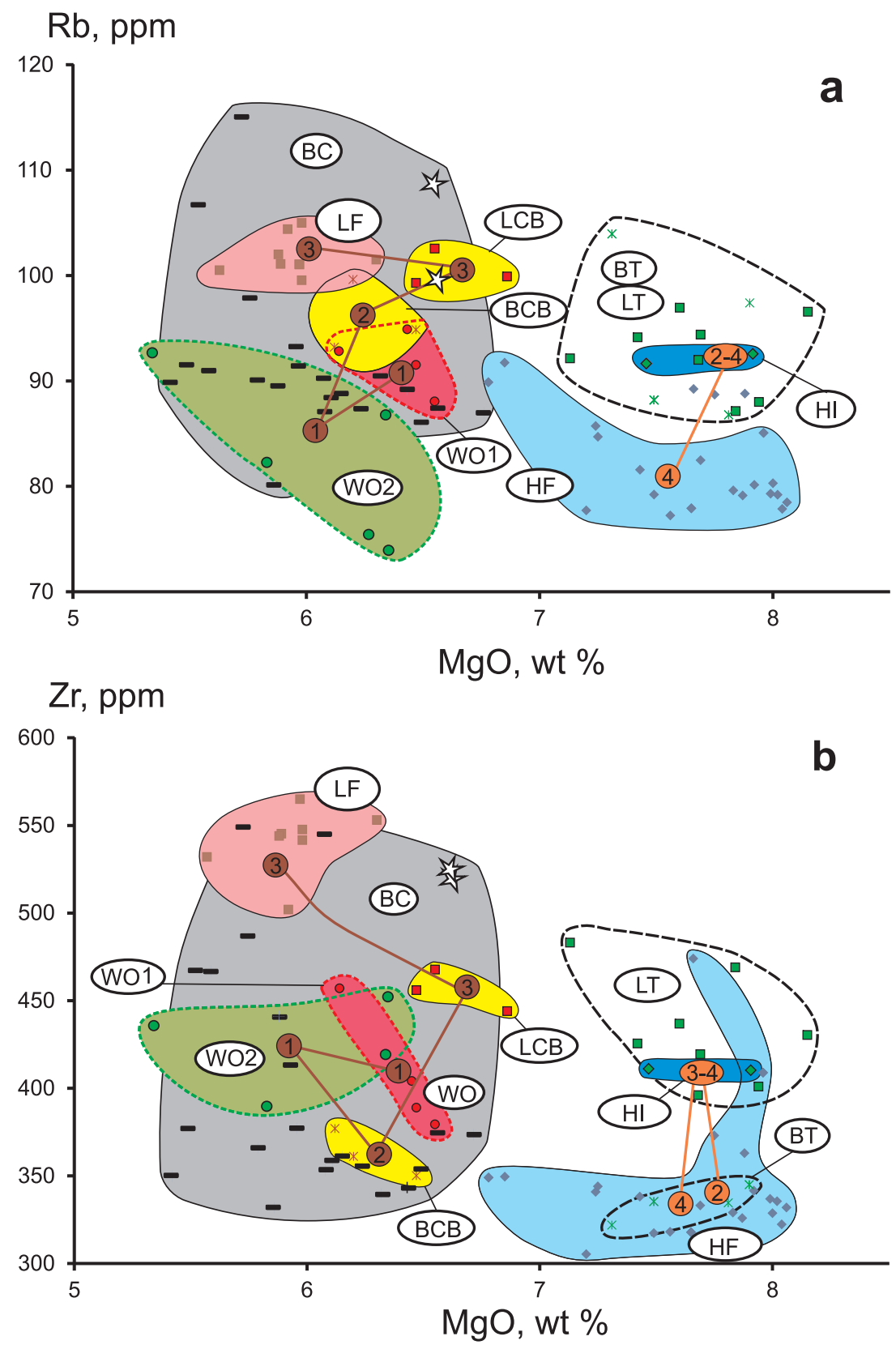

Fig. 14. Diagrams of Rb vs. $\mathrm{MgO}(a)$ and $\mathrm{Zr}$ vs. $\mathrm{MgO}(b)$ for volcanic rocks. The symbols are given in Fig. 8.

Рис. 14. Диаграммы Rb - MgO (a) и Zr - MgO (b) вулканических пород. Условные обозначения см. на рис. 8.

generation beneath the Wudalianchi field, we compare rock sources along the Wohushan-Huoshaoshan line and in background volcanoes and link a local stepwise compositional change of eruption products along the line with a crack that propagated in a layer of the lithosphere base in the central part of the transtensional segment.

\subsection{COMPONENTS OF POTASSIC ROCK SOURCES}

Sub-lithospheric continuum of components under East Asia comprises a material from the convective mantle domain with subducted slab (paleoslab) frag- ments of the oceanic (paleooceanic) crust, as well as delaminated lithospheric blocks of orogens. Volcanic rocks from the Wudalianchi field show a sub-lithospheric end-member that belongs to this continuum, but lithospheric components of these rocks, however, have no connection with other sub-lithospheric components. We refer the Wudalianchi rocks to a sub-lithosphericlithospheric cluster of components from the boundary between the lithosphere and sub-lithospheric convective mantle (Fig. 17).

An enriched mantle source begins to melt at lower temperature than a depleted source due to elevated concentrations of fluids. Incompatible fusible compo- 

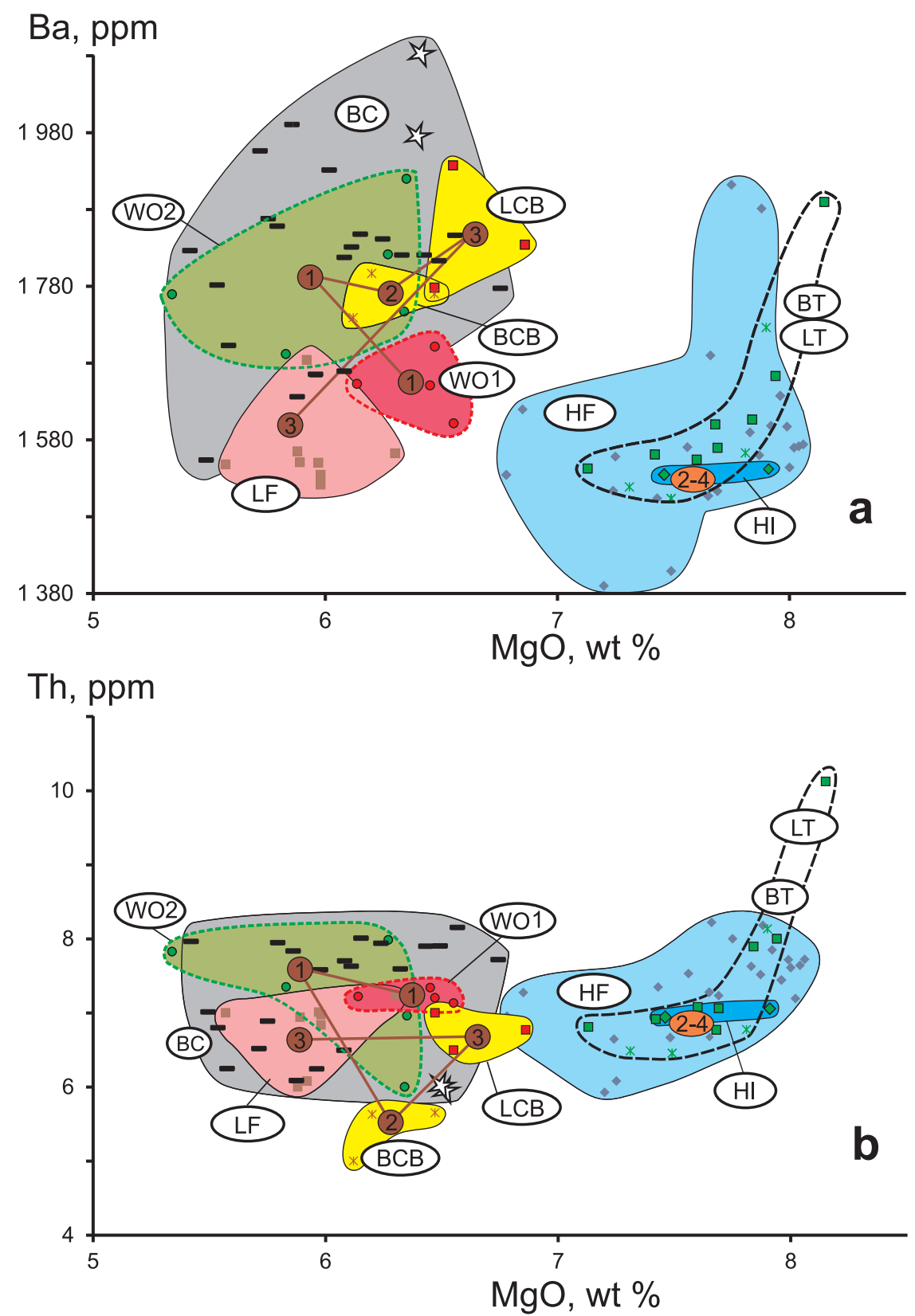

Fig. 15. Diagrams of Ba vs. $\mathrm{MgO}(a)$ and Th vs. $\mathrm{MgO}(b)$ for volcanic rocks. The symbols are given in Fig. 8.

| Рис. 15. Диаграммы Ва - MgO (a) и Th - MgO (b) вулканических пород. Условные обозначения см. на рис. 8.

nents are concentrated in low-volume liquids, whereas compatible elements of slightly melted medium are held in a restite. As the degree of melting increases, concentrations of incompatible elements in melts decrease and concentrations of compatible elements, on the contrary, increase. Such a change of liquid compositions occurs in the enriched mantle under rising temperatures. In a study of melting enriched sources, one should trace a relative role of compatible and incompatible elements that have isomorphic relationships in crystal structures.

We examine a behavior of strontium that isomorphically replaces calcium in apatite, clinopyroxene, garnet, amphibole, plagioclase, calcite, and possibly in other calcium-bearing minerals. In terms of a compatible oxide $\mathrm{CaO}$, rocks from the Wohushan, Bijiashan, and Laoheishan volcanoes (except final pyroclastics of the latter volcano) fall between the background rocks $(\mathrm{CaO}=5.0-6.3$ wt \%) and rocks from the Huoshaoshan volcanic cone $(\mathrm{CaO}=7.1-8.1 \mathrm{wt} \%)$. Wide ranges of $\mathrm{Sr}$ concentrations in the background and final Huoshaoshan rocks are comparable with the range of this element in transitional rocks from the Laoheishan volcano. Similarly, narrow ranges of $\mathrm{Sr}$ concentrations in rocks from the Wohushan, Bijiashan, and Laoheishan volcanoes close to background, are comparable with 

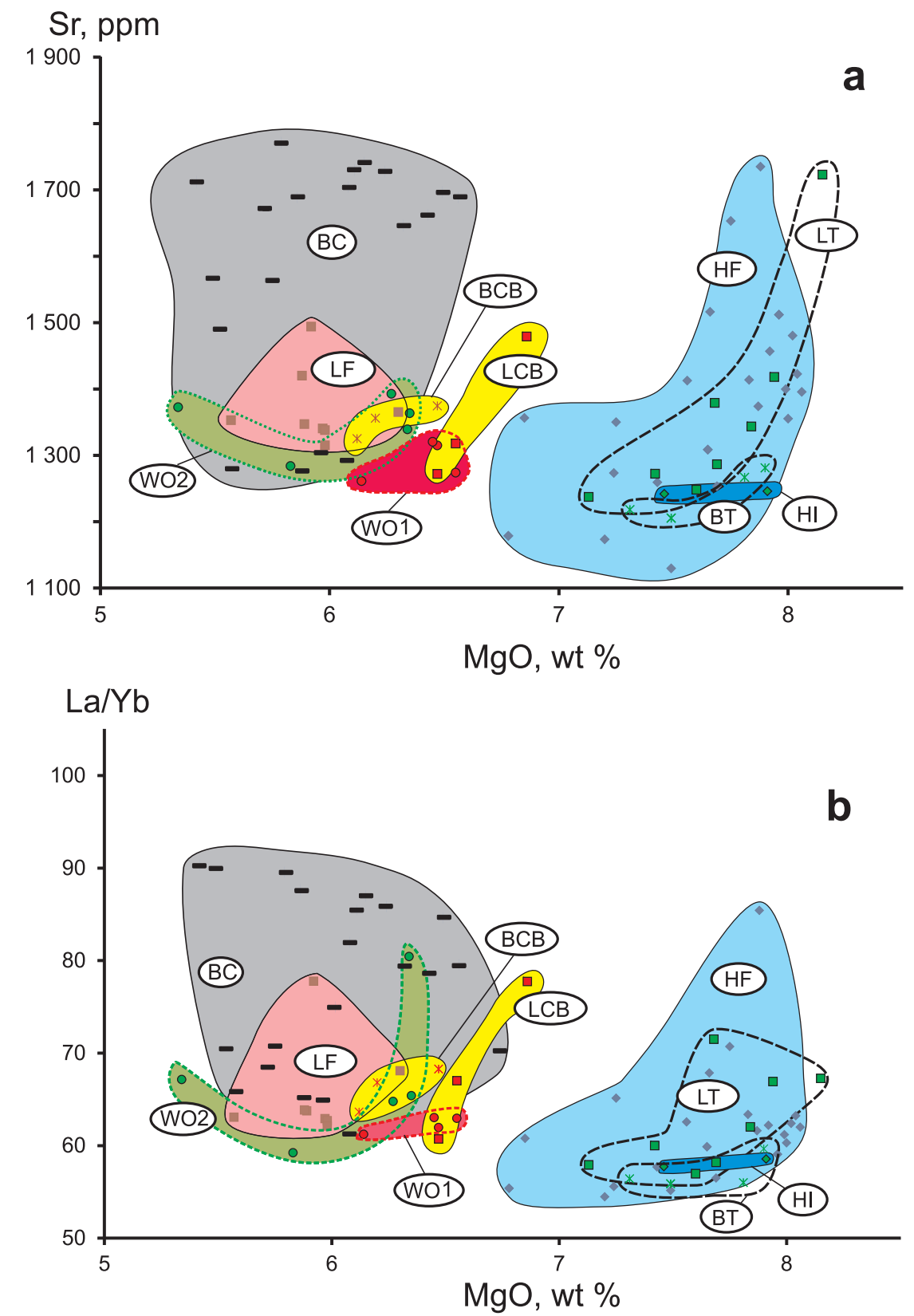

Fig. 16. Diagrams of Sr vs. $\mathrm{MgO}(a)$ and La/Yb vs. $\mathrm{MgO}(b)$ for volcanic rocks. The symbols are given in Fig. 8.

| Рис. 16. Диаграммы $\mathrm{Sr}-\mathrm{MgO}(a)$ и La/Yb - MgO (b) вулканических пород. Условные обозначения см. на рис. 8.

the range of this element in transitional rocks from the Bijiashan volcano and initial Huoshaoshan flows (Fig. $18, a)$.

In transitional rocks from the Laoheishan volcano, increasing $\mathrm{CaO}$ contents are accompanied with increasing Sr concentrations from values of the initial eruptions at the Huoshaoshan volcano to the maximal values of its final eruptions. Thus, in terms of $\mathrm{CaO}$ and $\mathrm{Sr}$ contents, a common source material is defined in these two volcanoes.

In rocks from the early to late volcanoes of the Central group, $\mathrm{CaO}$ contents were increasing with expanding ranges of $\mathrm{Sr}$ concentrations. This is indicative of the temporal intensification of melting processes. Strontium concentrations in the Wohushan rocks, close to the background values, decrease slightly to the transitional ones from the Bijiashan volcano and reach a minimum in rocks from the final Huoshaoshan cone. Taking into account the decreasing low limits of Sr concentrations in the material erupted at the Laoheishan and Huoshaoshan volcanoes, one has to admit this trend as an indication of a possible change of sources.

On the diagram of $\mathrm{CaO} / \mathrm{Sr}$ vs. $\mathrm{MgO}$ (Fig. 18, $b$ ), transitional rocks from the Laoheishan cone are comparable to the initial Huoshaoshan rocks and, consequently, belong to the same source. Each of these volcanoes 


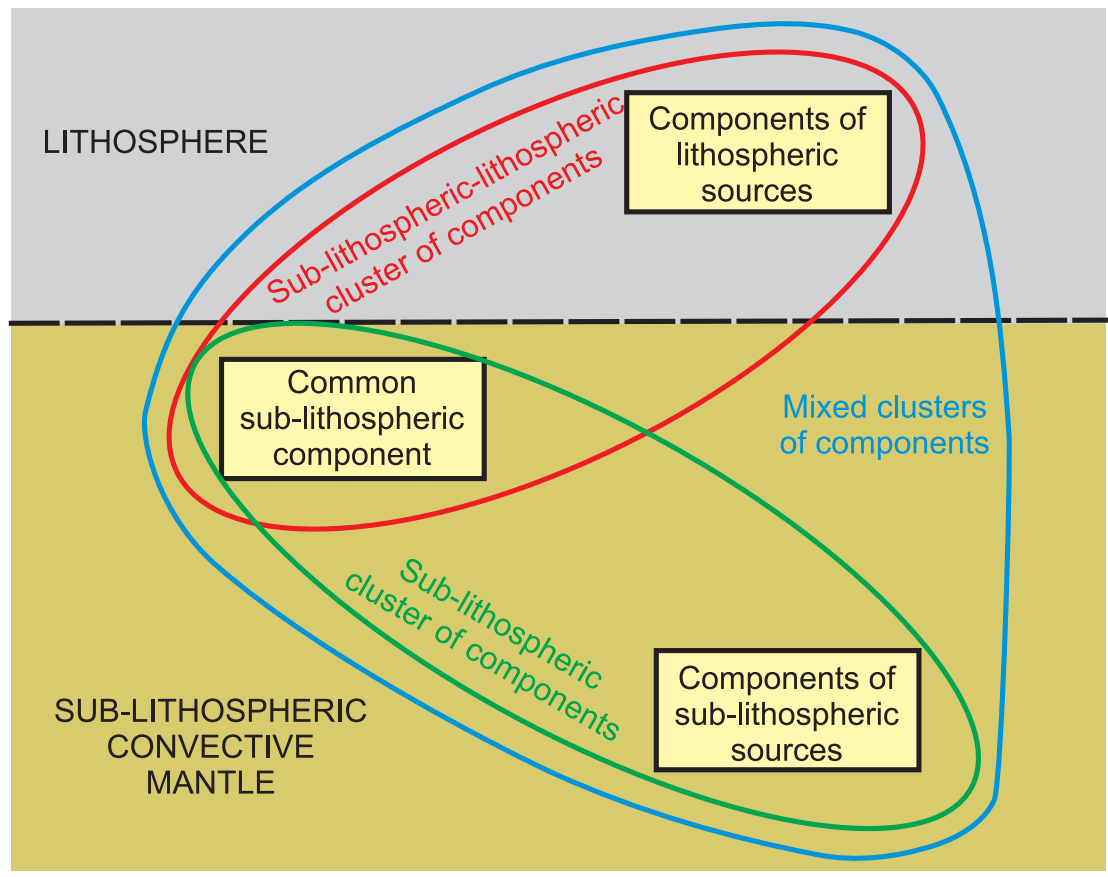

Fig. 17. Possible relationships between a common sub-lithospheric component of convective mantle and components of lithospheric versus sub-lithospheric sources for volcanic rocks.

Рис. 17. Возможные соотношения общего подлитосферного компонента конвектирующей мантии с компонентами литосферных и подлитосферных источников вулканических пород.

evolved with the changing erupted material due to its outcome from an additional source. On the one hand, a source for bombs from the late Laoheishan crater was similar to the background one, while most of its erupted material was affected with crustal contamination, which resulted in a remarkable decrease in $\mathrm{CaO} / \mathrm{Sr}$, as well as $\mathrm{CaO}$ and $\mathrm{MgO}$ contents (see the next section). On the other hand, a source of rocks from the final Huoshaoshan cone produced the material with a higher degree of melting, expressed in an increasing $\mathrm{CaO} / \mathrm{Sr}$ ratio at lower $\mathrm{Sr}$ concentrations and elevated $\mathrm{CaO}$ contents.

Low $\mathrm{CaO} / \mathrm{Sr}$ ratios at low $\mathrm{MgO}$ contents in the background rocks and higher $\mathrm{CaO} / \mathrm{Sr}$ ratios at elevated $\mathrm{MgO}$ contents in the transitional compositions of the Bijiashan and Laoheishan volcanoes, as well as in advanced compositions of the Huoshaoshan volcano (Fig. 18, b), reflect activity of two contrasting types of sources, respectively, with low and higher temperatures of melts reflected in low and higher degrees of melting. In fact, all rocks from the Central group of volcanoes show $\mathrm{CaO} / \mathrm{Sr}$ ratios in excess of those in the background rocks. This difference demonstrates a general change of magma generating processes from margins of the $\mathrm{Wu}$ dalianchi field to its central part.

A common $\mathrm{P}_{2} \mathrm{O}_{5}-\mathrm{Sr}$ trend and individual $\mathrm{P}_{2} \mathrm{O}_{5}-\mathrm{CaO}$ trends for different groups of rocks (Fig. 19, $a, b$ ) indicate that $\mathrm{Sr}$ concentrations in liquids are governed by melting of an apatite-bearing source, whereas $\mathrm{CaO}$ contents depend on involvement of other Ca-bearing minerals in background sources of the Western and Eastern groups of volcanoes, on the one hand, and in sources of the Central group of volcanoes, on the other hand.

In apatites from metasomatized mantle xenoliths, $\mathrm{Sr}$ contents reach $4.4 \mathrm{wt} \%$ at $\mathrm{Zr}$ concentrations of $22 \mathrm{ppm}$ and less [Exley, Smith, 1982; O'Reilly, Griffin, 2000]. Therefore, small-volume melt fractions from an apatitebearing source can be traced by high $\mathrm{Sr}$ concentrations and $\mathrm{Sr} / \mathrm{Zr}$ ratios. Such a high-Sr component with $\mathrm{Sr} / \mathrm{Zr}>5$ indicates initial isotopic ratio ${ }^{87} \mathrm{Sr} /{ }^{86} \mathrm{Sr}=$ $=0.70491$ defined at intersecting trends of transitional compositions of the Laoheishan volcano and final compositions of the Huoshaoshan cone (Fig. 20, $a, b$ ). The final rocks from the Huoshaoshan volcano demonstrate a trend of mixing between the high-Sr component of a mantle lithospheric source and a common component of sub-lithospheric convective mantle with the parameters [Chuvashova et al., 2009; Rasskazov et al., 2011]: $10^{3} / \mathrm{Sr}=\sim 1.41 / \mathrm{ppm}(\mathrm{Sr}=\sim 700 \mathrm{ppm}), \mathrm{Sr} / \mathrm{Zr}=\sim 2$, initial ${ }^{87} \mathrm{Sr} /{ }^{86} \mathrm{Sr}=0.7052$. Transitional compositions of the Laoheishan volcano show another mixing between the same high-Sr component and less-Sr one ( $\mathrm{Sr}=1300$ $\mathrm{ppm}, 10^{3} / \mathrm{Sr}=0.771 / \mathrm{ppm}, \mathrm{Sr} / \mathrm{Zr}=\sim 3$ ) with strontium isotope signature similar to the value of the common sub-lithospheric source. It is likely that the less-Sr 

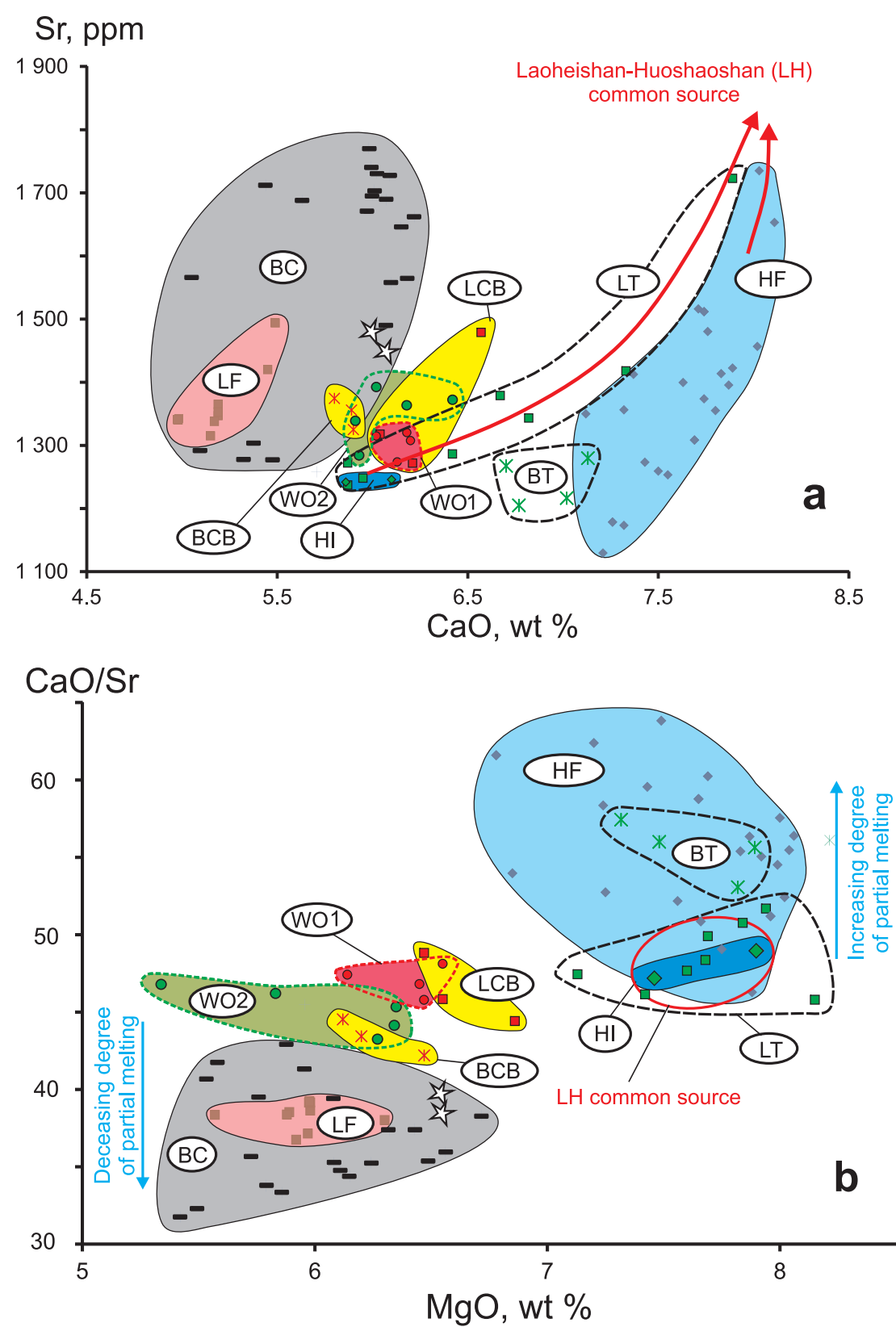

Fig. 18. Diagrams of $\mathrm{Sr}$ vs. $\mathrm{CaO}(a)$ and $\mathrm{CaO} / \mathrm{Sr}$ vs. $\mathrm{MgO}(b)$ for volcanic rocks. The symbols are given in Fig. 8.

Рис. 18. Диаграммы $\mathrm{Sr}-\mathrm{CaO}(a)$ и $\mathrm{CaO} / \mathrm{Sr}-\mathrm{MgO}(b)$ вулканических пород. Условные обозначения см. на рис. 8.

component originated from the small-degree (as compared to sub-lithospheric material) melting lithospheric medium that experienced transformation by fluids, rising from the sub-lithospheric convective mantle. Components with the same Sr-isotope ratio and varying concentrations of $\mathrm{Sr}$ characterize transitional rocks from the Bijiashan volcano as well as the background rocks. The latter show also the higher Sr-isotope ratios at relatively low $\mathrm{Sr} / \mathrm{Zr}$ values (2.2-3.2).

On the diagram in Fig. 20, $b$, additionally plotted data points of flows sampled near the Laoheishan volcano [Chu et al., 2013] are subdivided into two groups. One group falls on the trend of transitional rocks from the late volcanic cone of this volcano, another group shifts to the field of background compositions, enriched by radiogenic strontium.

Isotopic heterogeneity of sources for the lava flows related to the Huoshaoshan volcano is obvious from the data on samples taken from lava flows to the northeast and east of the volcanic cone by Chu et al. [2013]. Data points of these samples, shifted from the data field of the volcanic cone, demonstrate notably increasing ${ }^{87} \mathrm{Sr} /{ }^{86} \mathrm{Sr}$ ratios. Points of both the northeastern (garnito site) and eastern samples fall on the trend of transitional rocks from the Laoheishan volcano and, therefore, demonstrate Sr-isotope heterogeneity typical for 

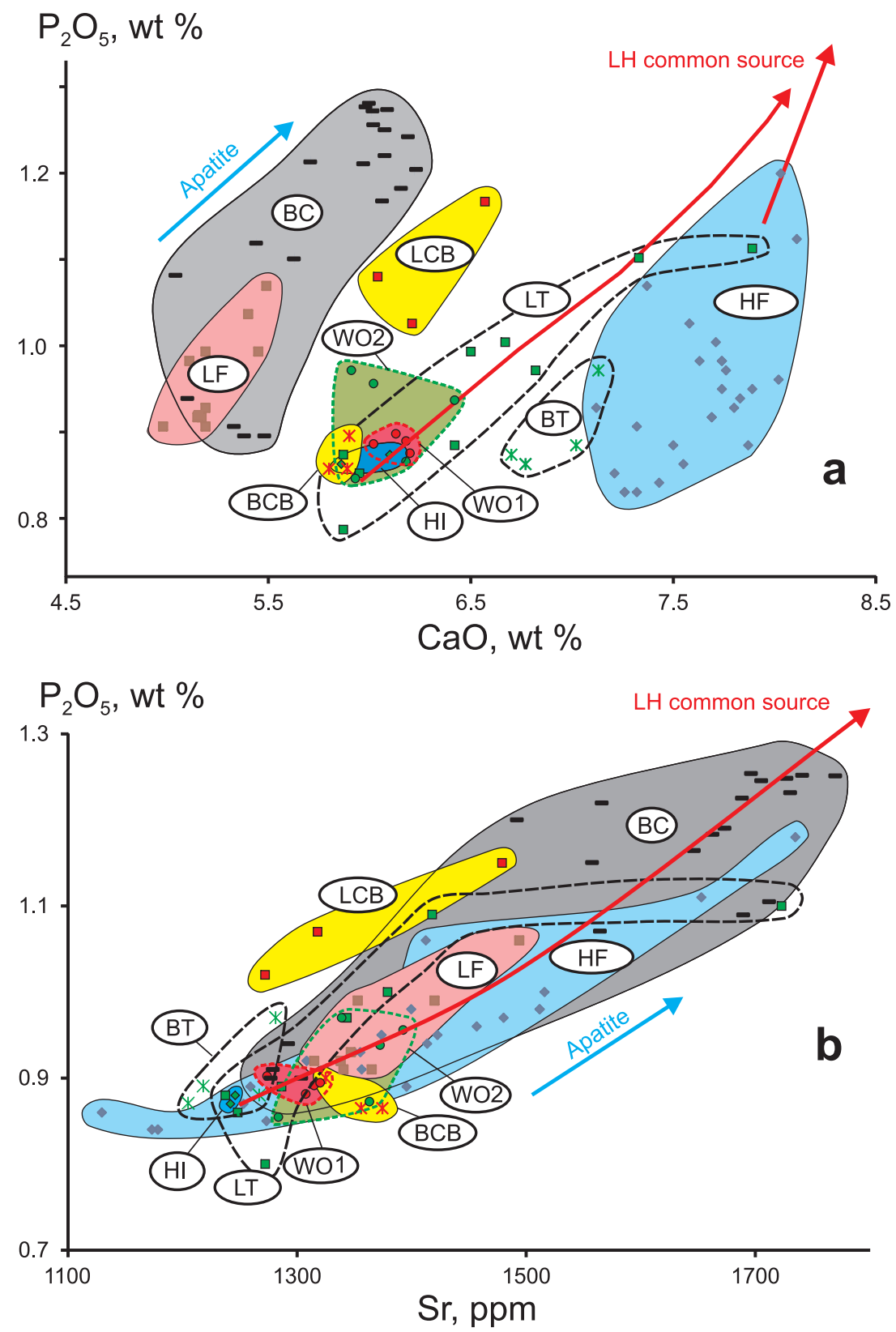

| Fig. 19. Diagrams of $\mathrm{P}_{2} \mathrm{O}_{5}$ vs. $\mathrm{CaO}(a)$ and $\mathrm{P}_{2} \mathrm{O}_{5}$ vs. $\mathrm{Sr}(b)$ for volcanic rocks. The symbols are given in Fig. 8.

Рис. 19. Диаграммы $\mathrm{P}_{2} \mathrm{O}_{5}-\mathrm{CaO}(a)$ и $\mathrm{P}_{2} \mathrm{O}_{5}-\mathrm{Sr}(b)$ вулканических пород. Условные обозначения см. на рис. 8.

this volcano. The trend of mixing between low-Sr sub-lithospheric and high-Sr lithospheric components characterizes the rocks sampled only from the final Huoshaoshan cone (see Fig. $3, b$ ).

\subsection{TIMING OF PROCESSES IN LITHOSPHERIC AND SUB-LITHOSPHERIC SOURCES}

There were some attempts to constrain timing of enrichment events for the WEK source by model isotopic ages. The estimate of $2.4 \mathrm{Ga}$ was obtained from the two-stage $\mathrm{Pb}$ evolution model and the estimate of 800-900 Ma from the $\mathrm{Nd}\left(\mathrm{T}_{\mathrm{dm}}\right)$ evolution model. It was inferred that "...the WEK lithospheric mantle source was modified during an early Proterozoic metasomatic event and was then isolated until the onset of the potassic magmatism" [Zhang et al., 1995, p. 1293]. A similar model approach was applied to explain the geochemical characteristics of the Wudalianchi basalts as derivatives from a deep stagnant slab. It was proposed that both the potassic- and EM1-like signatures of the basalts originated from the mantle transition zone, metasomatized by K-rich sediment fluids $\sim 1.5 \mathrm{Ga}$ ago through a stagnation of an ancient slab [Kuritani et al., 2013]. These and other Pre-Cambrian estimates assume a complex nature of protoliths involved in 


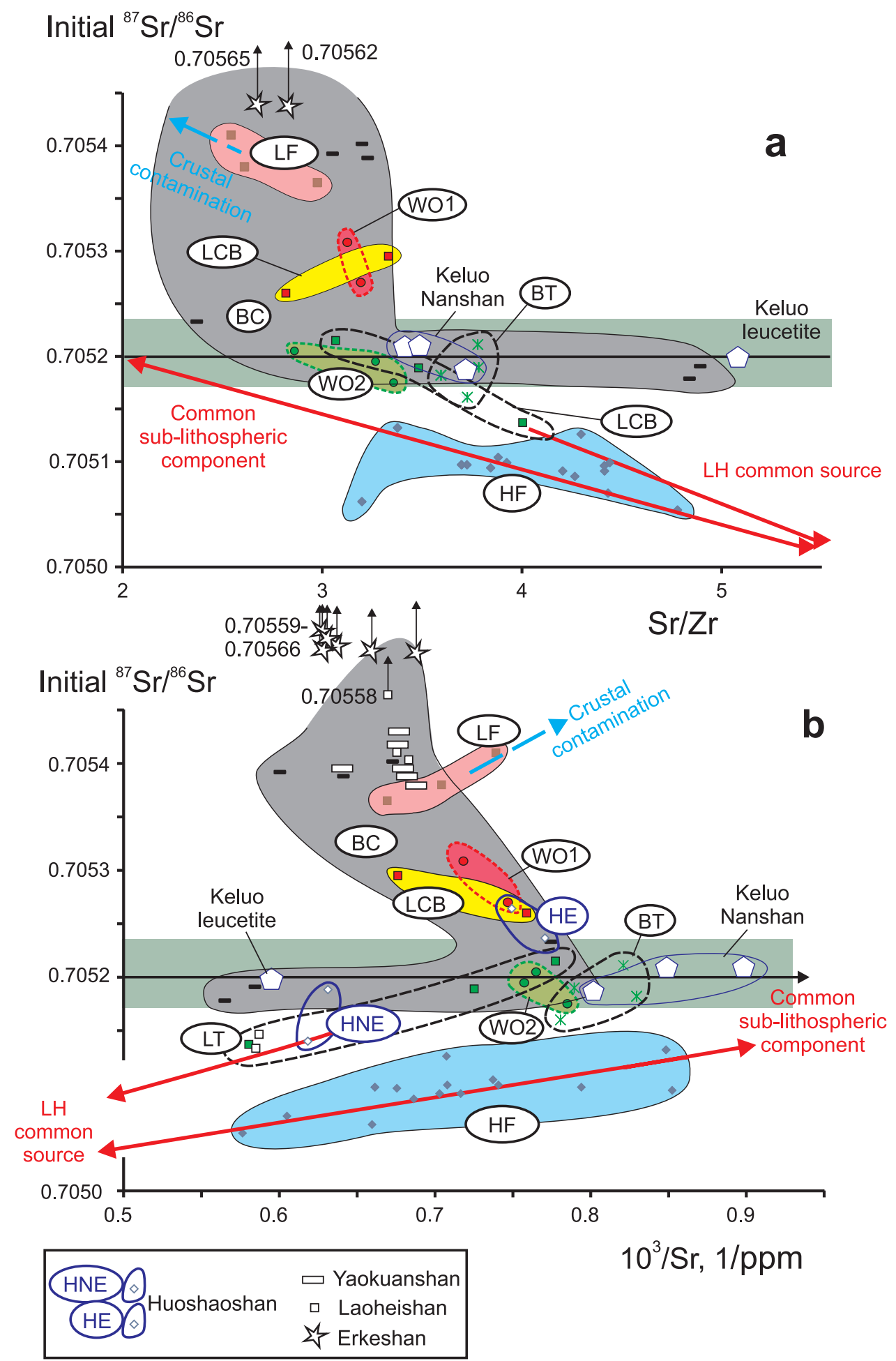

Fig. 20. Diagrams of initial ${ }^{87} \mathrm{Sr} /{ }^{86} \mathrm{Sr}$ vs. $\mathrm{Sr} / \mathrm{Zr}(a)$ and initial ${ }^{87} \mathrm{Sr} /{ }^{86} \mathrm{Sr}$ vs. $10^{3} / \mathrm{Sr}(b)$ for volcanic rocks.

The symbols are given in Fig. 8. Additionally shown are contrasting Sr-isotope compositions of lavas related to the Huoshaoshan volcano taken to the northeast of the cone (HNE - Huoshaoshan, northeast), to the east of it (HE - Huoshaoshan, east), and also Sr-isotope compositions of rocks from the Laoheishan and Yaoquanshan volcanoes and the Erkeshan volcanic field [Chu et al., 2013]. The value of initial ${ }^{87} \mathrm{Sr} /{ }^{86} \mathrm{Sr}=0.7052$ of the sub-lithospheric component is obtained with lower inverse $\mathrm{Sr}$ concentrations for olivine leucitite from the Dangzishan volcano and trachyandesites from the Nanshan volcano in the Keluo field.

Рис. 20. Диаграммы начального ${ }^{87} \mathrm{Sr} /{ }^{86} \mathrm{Sr}-\mathrm{Sr} / \mathrm{Zr}(a)$ и начального ${ }^{87} \mathrm{Sr} /{ }^{86} \mathrm{Sr}-10^{3} / \mathrm{Sr}(b)$ вулканических пород.

Усл. обозн. см. на рис. 8. Дополнительно показаны контрастные составы изотопов Sr в породах вулкана Хуошаошан, отобранных северо-восточнее конуса (HNE - Huoshaoshan, northeast) и восточнее его (HE - Huoshaoshan, еast), в породах вулканов Лаохейшан и Йаоцюаншан, а также поля Еркешан [Chu et al., 2013]. Значению начального ${ }^{87} \mathrm{Sr} /{ }^{86} \mathrm{Sr}=0.7052$ подлитосферного компонента с более низкими обратными концентрациями $\mathrm{Sr}$ соответствуют изотопные отношения $\mathrm{Sr}$ оливинового лейцитита и пород вулкана Наншан поля Келуо. 


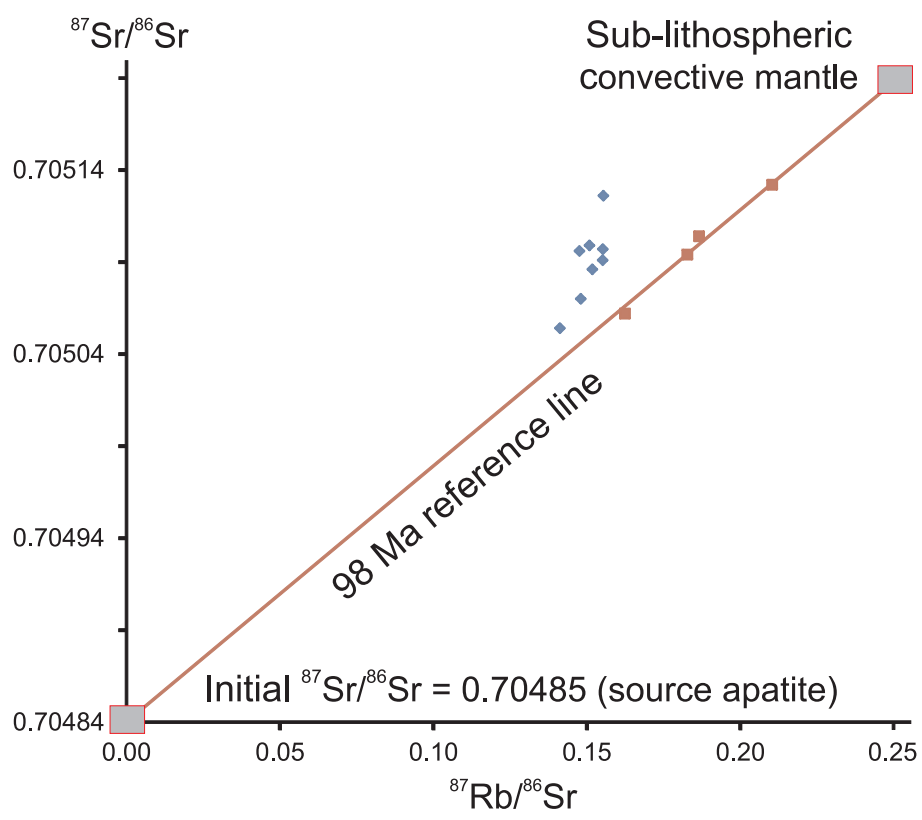

Fig. 21. The diagram of ${ }^{87} \mathrm{Sr} /{ }^{86} \mathrm{Sr}$ vs. ${ }^{87} \mathrm{Rb} /{ }^{86} \mathrm{Sr}$ for volcanic rocks from the Huoshaoshan cone.

Four data points (red squares) are distributed along the $98 \mathrm{Ma}$ reference line. This age interpretation assumes equal bulk mineral-melt partition coefficients in a source region for $\mathrm{Rb}$ and $\mathrm{Sr}$. Other points (blue rhombs) are plotted above the line.

Рис. 21. Диаграмма ${ }^{87} \mathrm{Sr} /{ }^{86} \mathrm{Sr}-{ }^{87} \mathrm{Rb} /{ }^{86} \mathrm{Sr}$ вулканических пород конуса Хуошаошан.

Четыре фигуративные точки (красные квадраты) распределены вдоль линии 98 млн лет. Такая возрастная интерпретация предполагает равенство валовых коэффициентов распределения минерал-расплав в источнике для Rb и Sr. Другие точки расположены выше этой линии (синие ромбы).

melting without any geologically reasonable grounds related to the Late Phanerozoic geological setting of potassic series.

It is noteworthy that the character of geological evolution of East Asia such as Mesozoic inland migrating volcanic arcs, multiple magmatic intrusions, subsidence of the Songliao and other basins etc. is indicative of significant Late Phanerozoic sub-lithospheric activity of the upper mantle. On the background of the complex protoliths signatures in a source region, one should find a way to register these processes.

Because of the short period of radiogenic ${ }^{143} \mathrm{Nd}$ accumulation, time-integrated ${ }^{143} \mathrm{Nd} /{ }^{144} \mathrm{Nd}$ values might yield only slight variations related to Late Phanerozoic geological events on the background of significant isotopic heterogeneity created by long-term accumulations of this isotopes in older protoliths. Similarly, an uranium-lead isotopic system is also insensitive for age definitions of a younger lithospheric material because of strong older isotopic heterogeneity of $\mathrm{Pb}$ in a source region (i.e. older heterogeneous lithospheric substrate for potassic series). Meanwhile, a significant effect of radiogenic isotope accumulation after homogenization and differentiation can be expected in a $\mathrm{Rb}-\mathrm{Sr}$ isotopic system due to anomalous enrichment of a source region for potassic series with radioactive isotope ${ }^{87} \mathrm{Rb}$. The inferred change of melts from lithospheric to sub-lithospheric sources along the Wohushan-Huoshaoshan volcanic line makes the most probable $\mathrm{Rb}-\mathrm{Sr}$ isotopic registration of timing for convective homogenization of the sub-lithospheric material in rocks from the Huoshaoshan volcanic cone.

We suggest that a rubidium-free mineral phase (i.e. apatite) yields an initial Sr-isotope ratio in a source of the lithosphere base, while the common convective mantle component characterizes the time-integrated ${ }^{87} \mathrm{Sr} /{ }^{86} \mathrm{Sr}$ at a homogeneous reservoir of the evolved $\mathrm{Rb}-\mathrm{Sr}$ isotopic system. Through the extremely low row of four data points for rocks from the Huoshaoshan volcano in the diagram of ${ }^{87} \mathrm{Sr} /{ }^{86} \mathrm{Sr}$ vs. ${ }^{87} \mathrm{Rb} /{ }^{86} \mathrm{Sr}$, we get an estimate of about $98 \mathrm{Ma}$ for the isotopic system closure at the base of the lithosphere with the initial ${ }^{87} \mathrm{Sr} /{ }^{86} \mathrm{Sr}$ apatite-related value of 0.70485 and the underlying convective mantle domain with $\mathrm{Rb} / \mathrm{Sr}=0.092$ (Fig. 21). This event corresponds to the transition from the syn-rift to post-rift stage of the Songliao basin evolution, according to Wang et al. [2016]. According to the estimates, the thermal influence of the convective mantle material on the lithosphere base decreased in the Mid-Cretaceous, at the time of a "superplume" state of the Earth's mantle [Larson, 1991], when avalanche-like collapses of paleoslab fragments from the transition layer into the lower mantle could provide reverse hot flows from the lower to the upper mantle beneath suture zones and adjacent areas of the Phanerozoic paleooceans closed in Central and East Asia [Rasskazov, Chuvashova, 2016].

\subsection{Crustal Contamination}

The anomalous velocity structure of the crust implying the currently existing shallow magma chambers was identified through a local reduction of S-wave velocity in a depth range of $15-22 \mathrm{~km}$ under the Huoshaoshan, Laoheishan volcanic edifices and adjacent areas of the Wudalianchi field, using the receiver function method [He et al., 2003]. This anomalous structural heterogeneity of the crust beneath the volcanoes was confirmed also by results of magnetotelluric sounding [Zhan et al., 2006].

Chemical parameters of crustal contamination are obscure in the Wudalianchi eruption products due to enriched compositions of mantle magmatic liquids [Zhang et al., 1995]. Crustal xenoliths, often partially molten, were detected in all edifices of the volcanic field and were specifically emphasized in the Huoshaoshan volcanic rocks [McGee et al., 2015]. A trend of in- 
creasing Sr-isotope ratios with increasing inverse concentrations of $\mathrm{Sr}$ in rocks from the Huoshaoshan cone (see Fig. 20, b) is interpreted here as an evidence for mixing between components of the lithosphere base and the sub-lithospheric convective mantle. The trend was not significantly distorted by any crustal admixture. A small admixture of the lower crustal material (2-8 \%) to the Yaoquanshan, Laoheishan, Huoshaoshan, and Erkeshan rocks was assumed from variations of 1870 s/1880s ratios [Chu et al., 2013].

It is noteworthy, however, that sufficient contamination by the crustal material is quite obvious in the final pyroclastics related to the late crater of the Laoheishan volcano. Multiple small quartz-feldspar xenoliths are dispersed in the material that has low-Mg content $(\mathrm{MgO}=5.5-6.4 \mathrm{wt} \%)$ and, as compared to other low-Mg rocks from the Wudalianchi field, show elevated contents of $\mathrm{SiO}_{2}$ (52.3-54.0 wt \%), $\mathrm{K}_{2} \mathrm{O}$ (5.3-5.8 wt \%), $\mathrm{Na}_{2} \mathrm{O}+\mathrm{K}_{2} \mathrm{O}$ (9.2-9.5 wt \%), Ni (145-180 ppm), Zr (500$560 \mathrm{ppm})$ at lower contents of $\mathrm{Al}_{2} \mathrm{O}_{3}$ (13.5-14.2 wt \%), $\mathrm{CaO}$ (5.0-5.4 wt \%), and $\mathrm{Ba}$ (1500-1680 ppm) (Fig. 8$12,14,15)$. On the plot of initial ${ }^{87} \mathrm{Sr} /{ }^{86} \mathrm{Sr}$ vs. $10^{3} / \mathrm{Sr}$, three samples of this unite demonstrate elevated ${ }^{87} \mathrm{Sr} /{ }^{86} \mathrm{Sr}$ (0.705365-0.705410) and yield a typical trend of crustal contamination - increasing Sr-isotope ratios with increasing inverse concentrations of this element (see Fig. 20, b). No compositionally similar rocks occur in other volcanoes of the Central group.

Major element contents similar to those of contaminated rocks from the Laoheishan volcano were determined in samples taken by Chu et al. [2013] from the Huoshaoshan lava flows. The reported trace-element concentrations of the samples and Sr-isotope ratios differ, however, from the parameters obtained for the crust-contaminated rocks. For instance, $\mathrm{Zr}$ concentrations of the Huoshaoshan lava flows were defined in a range of 382-418 ppm.

\subsection{CONTROL OF POTASSIC VOLCANISM BY DEVELOPING TRANSTENSION ZONE}

The transtensional nature of magma-controlling processes was well pronounced in the Keluo and $\mathrm{Wu}$ dalianchi volcanic fields; extensional structures were expressed with northeastern volcanic loci under the general north-south direction of the zone (azimuth $353^{\circ}$ ). However, the fact that magmatism was not uniform along the zone is demonstrated by both different timing of volcanism and northward widening ranges of potassium contents in rocks (see Fig. 2).

Eruptions of olivine-leucitite magmas on the Keluo volcanic field with MgO contents as high as $14 \%$ reflected the adiabatic ascent of hot material in the sublithospheric convective mantle, focused in the oblique lithospheric fault of the Wudalianchi zone. These hightemperature magmas erupted along the northeastern (azimuth $51^{\circ}$ ) 42-km long line extended from the Dangzishan volcano in the southwest to the Xishan volcano in the northeast with a lateral widening up to $20 \mathrm{~km}$ in the field's center. An angle between the orientation of the Dangzishan-Xishan volcanic line and the general strike of the Wudalianchi zone is $58^{\circ}$.

In rocks from the Wudalianchi field, MgO contents do not exceed 8.2 wt \%. Unlike Keluo, this field shows magmatic processes that might develop without any additional heat supply by the adiabatically upwelling convective mantle. At the beginning of volcanism at $2.5 \mathrm{Ma}$, the thermal regime of the sub-lithospheric material under this area was probably close to the state of the ambient mantle. Such a material had no excess buoyancy flax and did not intrude into the lithosphere base.

On the Wudalianchi field, the initial lava eruptions of 2.5-2.0 Ma were displayed along the oblique locus of the main transtensional zone. A line of lava flows was directed at azimuth $7-8^{\circ}$. A small deviation of the oblique magma-controlling crack relative to the general strike of the zone (approximately $14-15^{\circ}$ ) is considered as an evidence for local decompression that initiated melting of the low-viscous sub-lithospheric material in the central part of this zone, which was only $7-10-\mathrm{km}$ wide and extended within an active $20-\mathrm{km}$ wide transtensional segment (Fig. 22, a).

After the volcanic lull of 2.0-1.3 Ma (Fig. 22, b), the less viscous lithosphere began melting. The $40-\mathrm{km}$ wide magmatically active transtensional zone and the 20-km wide Wudalianchi volcanic segment were comparable with these parameters of the Keluo volcanic field. The melting northeastern fragments deviated from the general strike of the zone by angles from $47^{\circ}$ to $52^{\circ}$, i.e. less than $58^{\circ}$, which is the angle characteristic of the deviation of the Dangzishan-Xishan line in the Keluo volcanic field. Reducing angles are indicative of the development of magmatic processes beneath the Wudalianchi area under conditions of the less viscous lithosphere than beneath the Keluo field. Unlike concentrated high-temperature reactivation of a single melting locus under the Keluo field, the lower-temperature processes in the mantle portion of the lithosphere beneath the Wudalianchi field provided for the development of a couple of sub-parallel oblique melting loci comprising a transtensional segment (Fig. 22, c).

In the last $0.6 \mathrm{Ma}$, the transtensional zone expanded to $55 \mathrm{~km}$, although the width of the segment (about $20 \mathrm{~km}$ ) remained relatively stable (Fig. 22, d). In the marginal parts of the segment, melting spread from the initial north-south magmatic locus in the axial part of the transtensional zone in opposite directions - from the southwest to northeast at the eastern margin and from northeast to southwest at the western margin (see Fig. 4). 

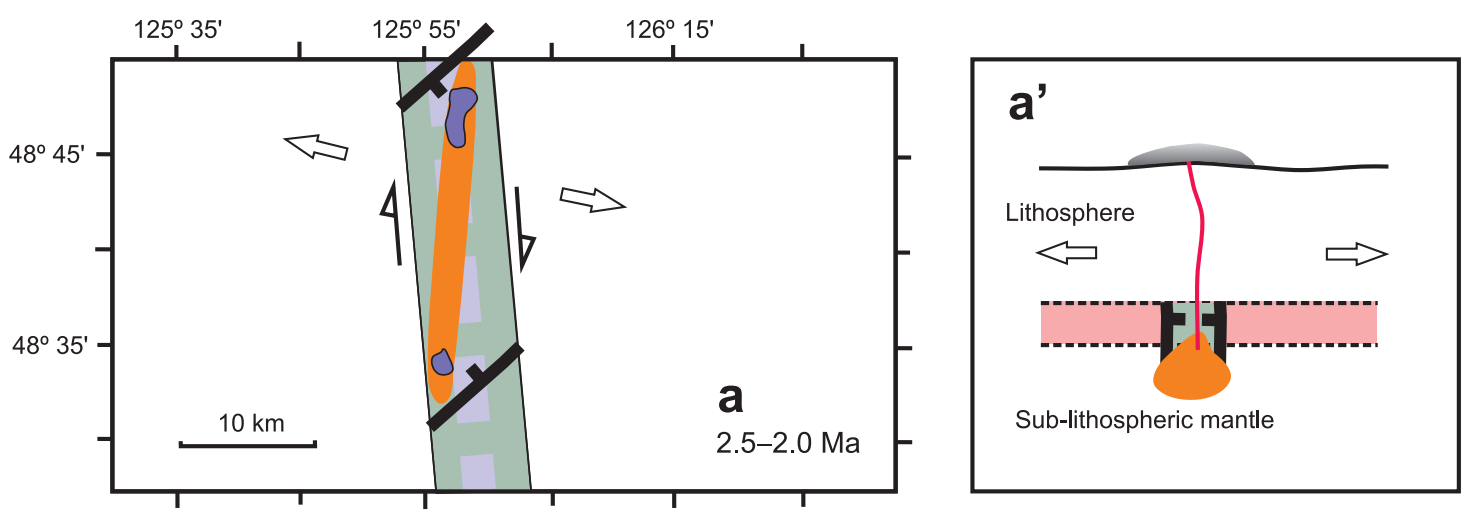

b

$2.0-1.3 \mathrm{Ma}$

Volcanic gap, reactivation of processes in the transtensional zone resulted in transfer of heat by fluids through the boundary shielding layer
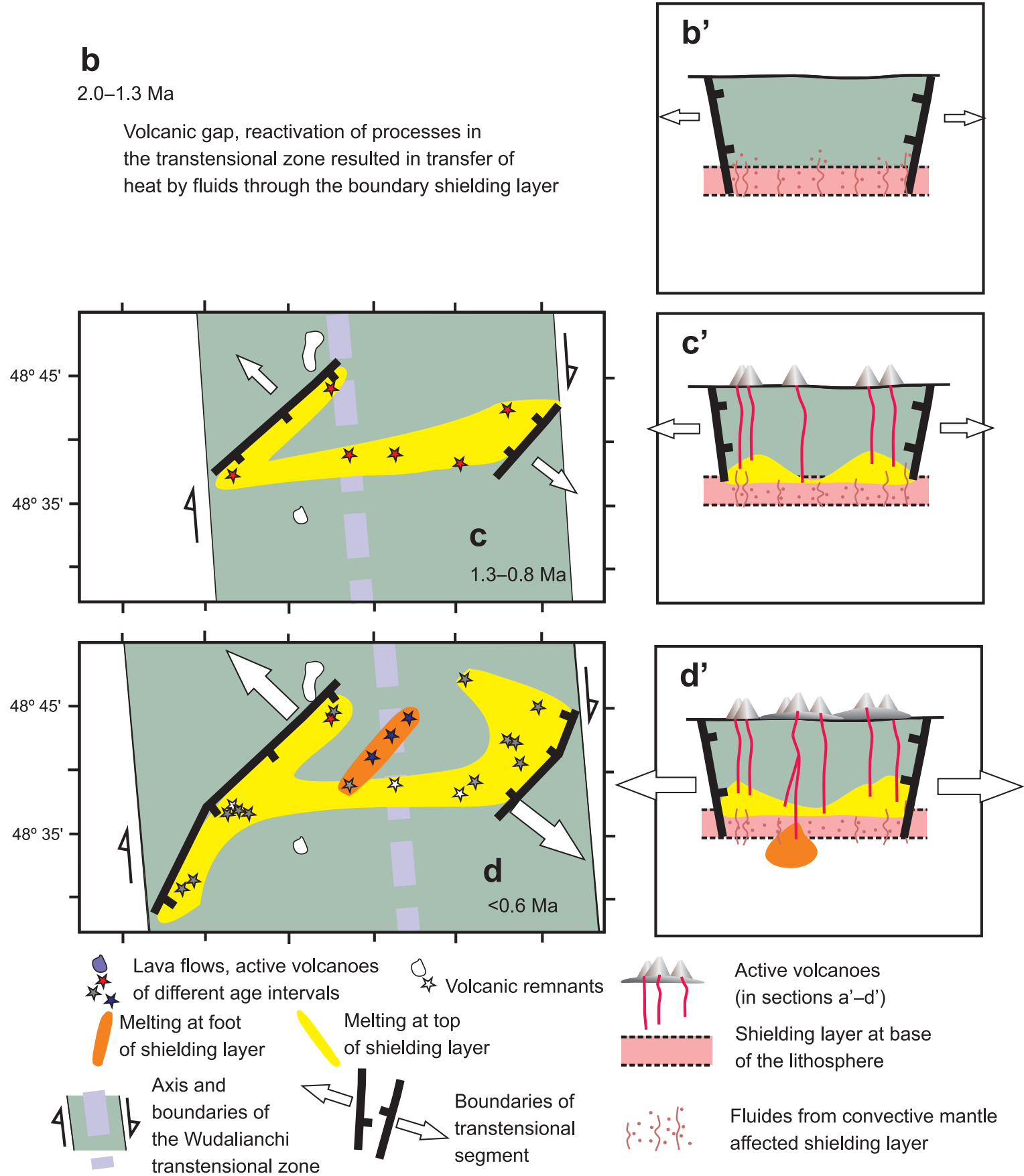

Active volcanoes

(in sections a'-d')

Shielding layer at base of the lithosphere

Fluides from convective mantle affected shielding layer

Fig. 22. Control of volcanism by a developing transtensional structure at a shielding layer of the lithospheric base in the Wudalianchi field $(a-d)$ and below $\left(a^{\prime}-d\right)$ (explanations in the text).

Рис. 22. Контроль вулканизма развивающейся структурой транстенсии в экранирующем слое основания литосферы на поле Удаляньчи $(a-d)$ и под ним $\left(a^{\prime}-d\right)$ (объяснения в тексте). 
Along the Wohushan-Huoshaoshan line, volcanic activity progressively shifted in the central part of the transtensional segment from the initial melting locus in the axial part of the transtensional zone northeastwards and was generally consistent with the temporal shift of activity in the Western group of volcanoes. The rate of volcanic shifting from the Laoshantou flow through the first entries of volcanic eruptions in the Wohushan and Bijiashan volcanoes to the Laoheishan one was about $0.8 \mathrm{~cm} \times y e a r-1^{-1}$ on average. This rate could correspond to the lateral convective propagation of the sub-lithospheric material from the initially reactivated axial part of the transtensional zone. It is likely that the further rapid shift of volcanic activity from the Laoheishan to Huoshaoshan cones over a distance of $3.5 \mathrm{~km}$ was provided by the crack propagation in the lithosphere.

\subsection{CHANGES OF SOURCES}

An estimated temperature at the lithosphereasthenosphere boundary under cratons at a depth of $200 \mathrm{~km}$ is as high as $1300{ }^{\circ} \mathrm{C}$ [O'Reilly, Griffin, 2010]. Under the off-craton regions of continents, a heat flux (that is generally higher than under cratons and the lithosphere-asthenosphere boundary) is recorded at shallower depths. The reference of the Wudalianchi erupted magmatic melts of 1720-1721 to the transition layer source was based on the assumed craton-like conductive heat flow of $40 \mathrm{~mW} / \mathrm{m}^{2}$ in the lithosphere [Kuritani et al., 2013]. This estimate of the current convective heat flow in the lithosphere can hardly be applied to describe the thermal state of the lithosphere base within the Wudalianchi segment as a part of the volcanically-active transtensional zone developed in the past $2.5 \mathrm{Ma}$. The lithosphere base was affected by warming up and should be characterized by elevated temperatures that ultimately might approach the estimate of the rift geotherm of Mercier [1980].

Taking into account the hypothesis on space-time control of volcanism by the developing Wudalianchi transtensional segment, we speculate that a primary heterogeneity of the transtensional segment was created at the lithosphere base in the course of the Late Mesozoic - Early Cenozoic deformations of the lithosphere when the Songliao basin subsided. This assumption is consistent with the Mid-Cretaceous (98 Ma) closure of the $\mathrm{Rb}-\mathrm{Sr}$ isotope system at the base of the lithosphere and the underlying convective mantle. In the Quaternary, the lithosphere base, that underwent transtensional deformations, was partly affected by fluids rising from the underlying convective mantle. A boundary layer of the lithosphere base shielded an overlying region of background melting from the sublithospheric convective mantle. The revealed spatialtemporal changes of components in melts that erupted in the Wudalianchi field mark deformations in the lower part of the shielding layer bordering the convective mantle domain, as well as deformations in its top that bourdered the enriched region of the lithosphere.

We suggest the following sequence of the processes:

1. Melting was initiated at the boundary between the shielding layer and the underlying convective mantle in the time interval of 2.5-2.0 Ma. Magma-generating decompression effects were concentrated along the narrow north-south melting locus and resulted in effusions of the Laoshantou and Old Gelaqiushan flows marked the initial low-angle oblique fragment of the transtensional zone.

2. The subsequent lack of efficiency of the magmagenerating processes resulted in a lull of volcanic activity in the time interval of 2.0-1.3 Ma. The initial reactivation of the transtensional segment could provide, however, the separation of fluids from the sub-lithospheric mantle and their penetration into the deformed parts of the shielding layer and partly into the overlying enriched region. The mass-and-heat transfer distorted the conductive lithospheric geotherm through increasing temperatures in the enriched region above the asthenosphere-lithosphere boundary layer.

3. At about 1.3 Ma, the temperature of the lithosphere base was elevated enough to initiate background melting of the lithosphere in the transtensional segment. By 0.8 Ma, the entire segment was enveloped by melting. The source of the first volcano of the Central group (Wohushan), which occurred in the background melting region, was followed by the material from cone 2 of this volcano, characterized by the initial ${ }^{87} \mathrm{Sr} /{ }^{86} \mathrm{Sr}$ values about 0.7052 , which are indicative of the occurrence of the source material modified by the sublithospheric mantle fluids.

4. In the past $0.6 \mathrm{Ma}$, background melting of the lithosphere advanced into the northeastern sector of the transtensional segment. This melting areal was firstly accompanied with magma generating processes beneath the second volcano of the line (Bijiashan), eruptions of which began with the material from the background region and continued with the material from the shielding layer modified by the sub-lithospheric mantle fluids. Later on, the sources of the third and fourth volcanoes of the line (Laoheishan and Huoshaoshan) were activated. The Laoheishan volcano could have erupted before 1720 . The initial phase of the short (1720-1721) activity in the Laoheishan volcano was exhibited by the pyroclastic material of the late cone and, afterwards, in a half of year after the end of its activity, by lava flows of the Huoshaoshan volcano. In both cases, sources were reactivated in the shielding boundary layer at the lithosphere base that had been modified by fluids that ascended from the sub-lithospheric convective mantle in the Mid-Cretaceous and Quaternary. The final explosive phase of the Laohei- 
shan volcano, which resulted in formation of the late crater, was provided by eruptions of liquids derived from the background lithospheric source and contaminated by the crustal material, whereas the final phase of the Huoshaoshan volcano was supplied by eruptions of liquids from the boundary shielding layer mixed with the sub-lithospheric material.

\section{ConCLUSION}

The Wudalianchi zone, traced with the PlioceneQuaternary potassic volcanic rocks, is strictly controlled by the lithospheric structure in the northern circuit of the Songliao basin that subsided in the Late Mesozoic - Early Cenozoic. The rock compositions vary along this zone in a stepwise pattern from the Erkeshan field $\left(\mathrm{K}_{2} \mathrm{O}\right.$ content of 5.6-5.8 wt \%) to the Xiaogulihe-Menlu field (contrasting $\mathrm{K}_{2} \mathrm{O}$ contents of about 2.0 wt $\%$ and 7.2-9.5 wt \%). This study has been focused on clarifying the character and nature of spatial-temporal variations of $\mathrm{K}_{2} \mathrm{O}$ contents in rocks from the Wudalianchi field, which range from 6.0 to $3.2 \mathrm{wt} \%$.

Considering the spatial-temporal compositional variations of rocks, we distinguish three time intervals of the volcanic evolution in the Wudalianchi field: (1) 2.5-2.0 Ma, (2) 1.3-0.8 Ma, and (3) $<0.6 \mathrm{Ma}$. At the beginning, lava flows erupted along the north-south Laoshantou - Old Gelaqiushan locus, then in the South Gelaqiushan volcano and along the west-east band of the Lianhuashan, Wohushan, Yaoquanshan, West Jiaodebushan, West Longmenshan volcanoes, and, finally, in three groups of volcanoes: Western (North Gelaqiushan, Lianhuashan, Jianshan-Jianshanzi), Central (Wohushan, Bijiashan, Laoheishan, Huoshaoshan) and Eastern (Weishan, East Jiaodebushan, Xiaogushan, West and East Longmenshan, Molabushan). The Western and Eastern groups exhibited irregular background eruptions of the last $1.3 \mathrm{Ma}$, whereas the Central group showed the stepwise northeastward shift of volcanic activity with an average rate of about $0.8 \mathrm{~cm}$ per year. On the one hand, the background erupted liquids displayed the limited range of $\mathrm{K}_{2} \mathrm{O}$ concentrations (4.8-6.0 wt \%), on the other hand, the migrated erupted melts demonstrated relatively reduced $\mathrm{K}_{2} \mathrm{O}$ contents at the beginning and at the end of the volcanic sequence.

The representative sampling revealed the stepwise changes of rock compositions in the Central group of volcanoes. On the first volcano (Wohushan), the rocks were compositionally close to the background ones. On the second and third volcanoes (Bijiashan and Laoheishan), the rocks were compositionally both close to the background rocks and different from them. On the final cone of the fourth volcano (Huoshaoshan), the rock compositions differed significantly from the back- ground ones. The background rocks showed specific compositions: $\mathrm{SiO}_{2}$ 51-55 wt \%, $\mathrm{CaO}$ 5.3-6.8 wt \%, $\mathrm{MgO}$ 5.3-7.0 wt \%, $\mathrm{K}_{2} \mathrm{O} / \mathrm{Na}_{2} \mathrm{O}=1.1-1.8$ wt $\%$, and $\mathrm{CaO} / \mathrm{Sr} 31-45$. The final Huoshaoshan rocks demonstrated decreesing $\mathrm{SiO}_{2}$ to $49 \mathrm{wt} \%$ and increasing $\mathrm{CaO}$ to $8.1 \mathrm{wt} \%, \mathrm{MgO}$ to $8.3 \mathrm{wt} \%, \mathrm{CaO} / \mathrm{Sr}$ to 65 .

From the analyses of the major, trace-element and Sr-isotope data on the volcanic rocks, we suggest that the stepwise propagation and jumps of volcanic activity along the Wohushan-Huoshaoshan line were accompanied by both the introduction of sub-lithospheric component into the melting region and melting of the crustal material. Extremely contrasting sources were defined in the 1720-1721 eruptive products, that included final pyroclastics from the late crater of the Laoheishan volcano contaminated with the crustal material, and the final lavas from the Huoshaoshan cone containing the admixture of the sub-lithospheric mantle component.

The established spatial-temporal variations in the rocks compositions are explained as a result of the magma generation control by the north-south transtensional zone in the layer of the lithospheric base that shielded the underlying sub-lithospheric convective mantle from the overlying more enriched lithosphere. Sub-lithospheric liquids were distinct due to the initial ${ }^{87} \mathrm{Sr} /{ }^{86} \mathrm{Sr}$ ratio of about 0.7052 , melts from the boundary shielding layer due to the same and lower ratios, and those from the overlying enriched lithosphere due to the same and higher ratios.

We proposed that the local venue of the convective mantle material from below the shielding layer and the melting enriched background material above it was governed by transtensional deformations. The eruptions of sub-lithospheric melts from the axial part of the main transtensional zone, which took place at 2.5-2.0 Ma, were followed by the propagation of the background liquids from the wider segment of the enriched lithospheric region at 1.3-0.8 Ma. In the past 0.6 $\mathrm{Ma}$, background melting progressed at the margins of the transtensional segment simultaneously with local melting along the crack that propagated in the boundary shielding layer under the central part of the background melting region.

\section{ACKNOWLEDGMENTS}

We thank Prof. Jiaqi Liu who arranged a survey of Cenozoic volcanic rocks in Northeast China in 20072013. The results obtained in these workshops served as a basis for creating the Chinese-Russian Wudalianchi-Baikal Research Center on volcanism and environment, in the framework of which this study was developed - grants No. P162011012 and of the Scientific Research Fund of the Heilongjiang Academy of Sciences 
(2016). We are grateful to Prof. Yogjiang Liu for his introduction into regional geology of Northeast China, which improved our understanding of the structural control of potassic volcanic rocks. We analyzed the trace-elements and isotopes using the equipment of the Microanalysis (Limnological Institute of SB RAS) and Geodynamics and Geochronology (Institute of the Earth's Crust SB RAS) Collective Use Centers. Samples for isotopic analysis of Sr were prepared by E.V. Saranina, and mass-spectrometer measurements were performed by N.N. Fefelov. Samples for trace-element analysis were prepared by M.E. Markova, and mass-spectrometer measurements and mass-corrections were performed by A.P. Chebykin. The "wet chemistry" analytical work was conducted by G.V. Bondareva and M.M. Samoilenko.

\section{REFERENCES}

Basu A.R., Junwen W., Wankang H., Guanghong X., Tatsumoto M., 1991. Major element, REE, and Pb, Nd and Sr isotopic geochemistry of Cenozoic volcanic rocks of Eastern China: implications for their origin from suboceanic-type mantle reservoirs. Earth and Planetary Science Letters 105 (1-3), 149-169. http://dx.doi.org/10.1016/0012821X(91)90127-4.

Bijwaard H., Spakman W., Engdahl E.R., 1998. Closing the gap between regional and global travel time tomography. Journal of Geophysical Research: Solid Earth 103 (B12), 30055-30078. http://dx.doi.org/10.1029/98JB02467.

Chen Y., Zhang Y., Graham D., Su S., Deng J., 2007. Geochemistry of Cenozoic basalts and mantle xenoliths in Northeast China. Lithos 96 (1-2), 108-126. http://dx.doi.org/10.1016/j.lithos.2006.09.015.

Choi S.H., Mukasa S.B., Kwon S.-T., Andronikov A.V., 2006. Sr, Nd, Pb and Hf isotopic compositions of late Cenozoic alkali basalts in South Korea: Evidence for mixing between the two dominant asthenospheric mantle domains beneath East Asia. Chemical Geology 232 (3-4), 134-151. http://dx.doi.org/10.1016/j.chemgeo.2006.02.014.

Chu Z.-Y., Harvey J., Liu C.-Z., Guo J.-H., Wu F.-Y., Tian W., Zhang Y.-L., Yang Y.-H., 2013. Source of highly potassic basalts in northeast China: evidence from Re-Os, Sr-Nd-Hf isotopes and PGE geochemistry. Chemical Geology 357, 52-66. http://dx.doi.org/10.1016/j.chemgeo.2013.08.007.

Chuvashova I.S., Rasskazov S.V., Liu J., Meng F., Yasnygina T.A., Fefelov N.N., Saranina E.V., 2009. Isotopically enriched component in the evolution of late Cenozoic potassic magmatism in Heilongjiang Province, Northeast China. Izvestiya Irkutskogo gosudarstvennogo universiteta, Seriya «Nauki o Zemle» (The Bulletin of Irkutsk State University, Earth Sciences Series) 2 (2), 181-198 [Чувашова И.С., Рассказов С.В., Лиу Я., Менг Ф., Ясныгина Т.А., Фефелов H.H., Саранина E.B. Изотопно-обогащенные компоненты в эволюции позднекайнозойского калиевого магматизма провинции Хейлонгджанг, Северо-Восточный Китай // Известия Иркутского государственного университета. Серия «Науки о Земле». 2009. Т. 2. № 2. С. 181-198].

Chuvashova I., Rasskazov S., Yasnygina T., 2016. Mid-Miocene thermal impact on the lithosphere by sub-lithospheric convective mantle material: Transition from high- to moderate-Mg magmatism beneath Vitim Plateau, Siberia. Geoscience Frontiers (in press) http://dx.doi.org/10.1016/j.gsf.2016.05.011.

Exley R.A., Smith J.V., 1982. The role of apatite in mantle enrichment processes and in the petrogenesis of some alkali basalt suites. Geochimica et Cosmochimica Acta 46 (8), 1375-1384. http://dx.doi.org/10.1016/0016-7037(82)902 73-3.

Fukao Y., Obayashi M., Inoue H., Nenbai M., 1992. Subducting slabs stagnant in the mantle transition zone. Journal of Geophysical Research: Solid Earth 97 (B4), 4809-4822. http://dx.doi.org/10.1029/91JB02749.

Fukao Y., Widiyantoro S., Obayashi M., 2001. Stagnant slabs in the upper and lower mantle transition region. Reviews of Geophysics 39 (3), 291-323. http://dx.doi.org/10.1029/1999RG000068.

Gilder S.A., Leloup P.H., Courtillot V., Chen Y., Coe R.S., Zhao X., Xiao W., Halim N., Cogné J-P., Zhu R., 1999. Tectonic evolution of the Tancheng-Lujiang (Tan-Lu) fault via Middle Triassic to Early Cenozoic paleomagnatic data. Journal of Geophysical Research: Solid Earth 104 (B7), 15365-15390. http://dx.doi.org/10.1029/1999JB900123.

Gudmundsson Ó., Sambridge M., 1998. A regionalized upper mantle (RUM) seismic model. Journal of Geophysical Research: Solid Earth 103 (B4), 7121-7136. http://dx.doi.org/10.1029/97JB02488.

Guide Book for Field Mission to Wudalianchi National Park, China, 2010. Prepared by Wudalianchi National Park and Nature Management Committee Heilongjiang province, $50 \mathrm{p}$.

Han G.Q., Liu Y.J., Neubauer F., Genser J., Zou Y.X., Li W., Liang C.Y., 2012a. Characteristics, timing, and offsets of the middle-southern segment of the western boundary strike-slip fault of the Songliao Basin in Northeast China. Science China Earth Sciences 55 (3), 464-475. http://dx.doi.org/10.1007/s11430-012-4362-y.

Han G., Liu Y., Neubauer F., Jin W., Genser J., Ren S., Li W., Wen Q., Zhao Y., Liang C., 2012b. LA-ICP-MS U-Pb dating and Hf isotopic compositions of detrital zircons from the Permian sandstones in Da Xing'an Mountains, NE China: New evidence for the eastern extension of the Erenhot-Hegenshan suture zone. Journal of Asian Earth Sciences 49, 249-271. http://dx.doi.org/10.1016/j.jseaes.2011.11.011.

He C.-S., Wang C.-Y., Wu J.-P., 2003. The velocity structure of crust and upper mantle in the Wudalianchi volcano area inferred from the receiver function. Acta Seismologica Sinica 16 (2), 140-147. http://dx.doi.org/10.1007/s11589003-0016-7. 
Hsu C-H., Chen J-C., 1998. Geochemistry of late Cenozoic basalts from Wudalianchi and Jingpohu areas, Heilongjiang Province, Northeast China. Journal of Asian Earth Sciences 16 (4), 385-405. http://dx.doi.org/10.1016/S07439547(98)00022-1.

Jolivet L., Tamaki K., Fournier M., 1994. Japan Sea, opening history and mechanism: A synthesis. Journal of Geophysical Research: Solid Earth 99 (B11), 22237-22259. http://dx.doi.org/10.1029/93JB03463.

Kuritani T., Kimura J.-I., Ohtani E., Miyamoto H., Furuyama K., 2013. Transition zone origin of potassic basalts from Wudalianchi volcano, northeast China. Lithos 156-159, 1-12. http://dx.doi.org/10.1016/j.lithos.2012.10.010.

Larson R.L., 1991. Latest pulse of Earth: Evidence for a mid-Cretaceous superplume. Geology 19 (6), 547-550. http:// dx.doi.org/10.1130/0091-7613(1991)019<0547:LPOEEF>2.3.CO;2.

Li S., Mooney W.D., Fan J., 2006. Crustal structure of mainland China from deep seismic sounding data. Tectonophysics 420 (1-2), 239-252. http://dx.doi.org/10.1016/j.tecto.2006.01.026.

Liu J., Taniguchi H., 2001. Active volcanoes in China. Northeast Asian Studies 6, 173-189.

Liu J., Han J., Fyfe W.S., 2001. Cenozoic episodic volcanism and continental rifting in Northeast China and possible link to Japan Sea development as revealed from K-Ar geochronology. Tectonophysics 339 (3-4), 385-401. http://dx. doi.org/10.1016/S0040-1951(01)00132-9.

McDonough W.F., Sun S.-S., 1995. The composition of the Earth. Chemical Geology 120 (3-4), 223-253. http://dx.doi. org/10.1016/0009-2541(94)00140-4.

McGee L.E., McLeod C., Davidson J.P., 2015. A spectrum of disequilibrium melting preserved in lava-hosted, partially melted crustal xenoliths from the Wudalianchi volcanic field, NE China. Chemical Geology 417, 184-199. http://dx. doi.org/10.1016/j.chemgeo.2015.09.023.

Mercier J.C.C., 1980. Single-pyroxene thermobarometry. Tectonophysics 70 (1-2), 1-37. http://dx.doi.org/10.1016/ 0040-1951(80)90019-0.

Neuendorf K.K.E., Mehl J.P. Jr., Jackson J.A., 2011. Glossary of Geology. Fifth edition, revised. American Geosciences Institute, Alexandria, Virginia, $783 \mathrm{p}$.

O'Reilly S.Y., Griffin W.L., 2000. Apatite in the mantle: implications for metasomatic processes and high heat production in Phanerozoic mantle. Lithos 53 (3-4), 217-232. http://dx.doi.org/10.1016/S0024-4937(00)00026-8.

O'Reilly S.Y., Griffin W.L., 2010. The continental lithosphere-asthenosphere boundary: Can we sample it? Lithos 120 (1-2), 1-13. http://dx.doi.org/10.1016/j.lithos.2010.03.016.

Rasskazov S.V., Chuvashova I.S., 2016. The latest geodynamics in Asia: Synthesis of data on volcanic evolution, lithosphere motion, and mantle velocities in the Baikal-Mongolian region. Geoscience Frontiers (in press). http://dx.doi org/10.1016/j.gsf.2016.06.009.

Rasskazov S.V., Chuvashova I.S., Liu Y., Meng F., Yasnygina T.A., Fefelov N.N., Saranina E.V., 2011. Proportions of lithospheric and asthenospheric components in Late Cenozoic K and K-Na lavas in Heilongjiang Province, Northeastern China. Petrology 19 (6), 568-600. http://dx.doi.org/10.1134/S0869591111050031.

Rasskazov S.V., Chuvashova I.S., Yasnygina T.A., Fefelov N.N., Saranina E.V., 2012. Potassic and Potassic-Sodic Volcanic Series in the Cenozoic of Asia. Academic Publishing House "Geo", Novosibirsk, 351 p. (in Russian) [Рассказов C.В., Чувашова И.С., Ясныгина Т.А., Фефелов Н.Н., Саранина Е.В. Калиевая и калинатровая вулканические серии в кайнозое Азии. Новосибирск: Академическое изд-во «Гео», 2012. 351 с.].

Romanovsky N.P., 1999. The Earth's Pacific Segment: Deep Structure, Granitoid Ore-Magmatic Systems. Institute of Tectonics and Geophysics, Khabarovsk, $167 \mathrm{p}$.

Utkin V.P., 2013. Shear structural paragenesis and its role in continental rifting of the East Asian margin. Russian Journal Pacific Geology 7 (3), 167-188. http://dx.doi.org/10.1134/s181971401303007x.

Van der Hilst R.D., Engdahl E.R., Spakman W., Nolet G., 1991. Tomographic imaging of subducted lithosphere below northwest Pacific island arcs. Nature 353 (6339), 37-43. http://dx.doi.org/doi:10.1038/353037a0.

Wang P., Xie X., Mattern F., Ren Y., Zhu D., Sun X., 2007. The Cretaceous Songliao Basin: Volcanogenic Succession, Sedimentary Sequence and Tectonic Evolution, NE China. Acta Geologica Sinica 81 (6), 1002-1011. http://dx.doi.org/ 10.1111/j.1755-6724.2007.tb01022.x.

Wang P.-J., Mattern F., Didenko A.N., Zhu D-F., Singer B., Sun X-M., 2016. Tectonics and cycle system of the Cretaceous Songliao Basin: An inverted active continental margin basin. Earth-Science Reviews 159, 82-102. http://dx.doi. org/10.1016/j.earscirev.2016.05.004.

Wang $Y$., Chen $H_{\text {., }}$ 2005. Tectonic controls on the Pleistocene-Holocene Wudalianchi volcanic field (northeastern China). Journal of Asian Earth Sciences 24 (4), 419-431. http://dx.doi.org/10.1016/j.jseaes.2003.12.010.

Wang Y., Mu L., Liu W., 1996. Regularity and Characteristics of Volcanic Activity at Wudalianchi, Heilongjiang. 30th International Geological Congress. Beijing, China, $14 \mathrm{p}$.

Wee S.M., 2002. Geochemistry and isotopic systematics of Cenozoic alkaline volcanic rocks in Korea and NE China. Neues Jahrbuch für Mineralogie-Abhandlungen 177 (3), 213-240. http://dx.doi.org/10.1127/0077-7757/2002/ 0177-0213.

Wei W., Xu J., Zhao D., Shi Y., 2012. East Asia mantle tomography: New insight into plate subduction and intraplate volcanism. Journal of Asian Earth Sciences 60, 88-103. http://dx.doi.org/10.1016/j.jseaes.2012.08.001. 
Xiao L., Wang C., 2009. Geologic features of Wudalianchi volcanic field, Northeastern China: Implications for Martian volcanology. Planetary and Space Science 57 (5-6), 685-698. http://dx.doi.org/10.1016/j.pss.2008.08.005.

Yanovskaya T.B., Kozhevnikov V.M., 2003. 3D S-wave velocity pattern in the upper mantle beneath the continent of Asia from Rayleigh wave data. Physics of Earth and Planetary Interiors 138 (3-4), 263-278. http://dx.doi.org/10.1016/ S0031-9201(03)00154-7.

Yasnygina T.A., Markova M.E., Rasskazov S.V., Pakhomova N.N., 2015. Determination of rare-earth elements Y, Zr, Nb, $\mathrm{Hf}, \mathrm{Ta}$, Th in reference specimens from DB series using inductuvely coupled plasma mass-spectromentry (ICP-MS). Industrial Laboratory. Diagnostics of Materials 81 (2), 10-20 (in Russian) [Ясныгина Т.А., Маркова М.Е., Рассказов С.В., Пахомова Н.Н. Определение редкоземельных элементов, Y, Zr, Nb, Hf, Ta, Т в стандартных образцах серии ДВ методом ИСП-МС // Заводская лаборатория. Диагностика материалов. 2015. Т. 81. № 2. C. 10-20].

Zhan Y., Zhao G., Wang J., Xiao Q., Tang J., Rokityansky I.I., 2006. Crustal electric conductivity structure for Wudalianchi volcanic cluster in the Heilongjiang province, China. Acta Petrologica Sinnica 22 (6), 1494-1502.

Zhang M., Menzies M.A., Suddaby P., Thirlwall M.F., 1991. EM1 signature from the post-Archean subcontinental lithospheric mantle: isotopic evidence from the potassic volcanic rocks in NE China. Geochemical Journal 25, 387-398.

Zhang M., Suddaby P., O'Reilly S.Y., 2000. Nature of the lithospheric mantle beneath the eastern part of the Central Asian fold belt: mantle xenolith evidence. Tectonophysics 328 (1-2), 131-156. http://dx.doi.org/10.1016/S00401951(00)00181-5.

Zhang M., Suddaby P., Thompson R.N., Thirlwall M.F., Menzies M.A., 1995. Potassic rocks in NE China: geochemical constraints on mantle source and magma genesis. Journal of Petrology 36 (5), 1275-1303. http://dx.doi.org/10.1093/ petrology/36.5.1275.

Zhang Y.-L., Liu C.-Z., Ge W.-C., Wu F.-Y., Chu Z.-Y., 2011. Ancient sub-continental lithospheric mantle (SCLM) beneath the eastern part of the Central Asian Orogenic Belt (CAOB): Implications for crust-mantle decoupling. Lithos 126 (3-4), 233-247. http://dx.doi.org/10.1016/j.lithos.2011.07.022.

Zhang Y.Q., Shi W., Dong S.W., 2003. Strike-slip and extensional tectonics of the Tan-Lu fault zone (Eastern China) from the Cretaceous to Cenozoic. EGS - AGU - EUG Joint Assembly, Abstracts from the meeting held in Nice, France, 6-11 April 2003. Abstract \#1949.

Zhao D., 2009. Multiscale seismic tomography and mantle dynamics. Gondwana Research 15 (3-4), 297-323. http:// dx.doi.org/10.1016/j.gr.2008.07.003.

Zhao Y-W., Li Ni., Fan Q-C., Zou H., Xu Y-G., 2014. Two episodes of volcanism in the Wudalianchi volcanic belt, NE China: Evidence for tectonic controls on volcanic activities. Journal of Volcanology and Geothermal Research 285, 170-179. http://dx.doi.org/10.1016/j.jvolgeores.2014.08.016.

Zou H., Fan Q., Yao Y., 2008. U-Th systematics of dispersed young volcanoes in NE China: Asthenosphere upwelling caused by piling up and upward thickening of stagnant Pacific slab. Chemical Geology 255 (1-2), 134-142. http://dx.doi.org/10.1016/j.chemgeo.2008.06.022.

Zou H., Reid M.R., Liu Y., Yao Y., Xu X., Fan Q., 2003. Constraints on the origin of historic potassic basalts from northeast China by U-Th disequilibrium data. Chemical Geology 200 (1-2), 189-201. http://dx.doi.org/10.1016/S00092541(03)00188-8.

Zou H., Zindler A., Xu X., Qi Q., 2000. Major, trace element, and Nd, Sr, and Pb isotope studies of Cenozoic basalts in SE China: mantle sources, regional variations, and tectonic significance. Chemical Geology 171 (1-2), 33-47. http:// dx.doi.org/10.1016/S0009-2541(00)00243-6.

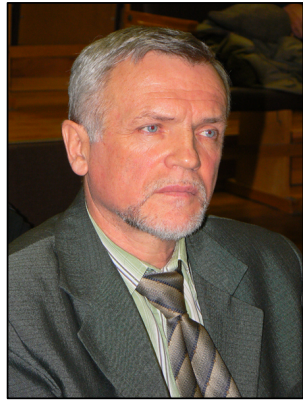

Rasskazov, Sergei V., Doctor of Geology and Mineralogy, Professor, Head of Laboratory Institute of the Earth's Crust, Siberian Branch of RAS

128 Lermontov street, Irkutsk 664033, Russia

Irkutsk State University, Geological Faculty

3 Lenin street, Irkutsk 664003, Russia

Tel. +7(3952)511659; \ e-mail: rassk@crust.irk.ru

Рассказов Сергей Васильевич, докт. геол.-мин. наук, профессор, зав. лабораторией

Институт земной коры СО РАН

664033, Иркутск, ул. Лермонтова, 128, Россия

Иркутский государственный университет, геологический факультет

664003, Иркутск, ул. Ленина, 3, Россия

Тел. (3952)511659; \ e-mail: rassk@crust.irk.ru 


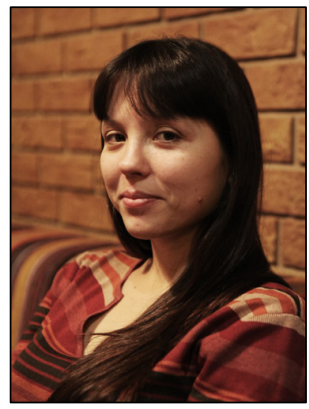

Chuvashova, Irina S., Candidate of Geology and Mineralogy, Senior Researcher Institute of the Earth's Crust, Siberian Branch of RAS

128 Lermontov street, Irkutsk 664033, Russia

Irkutsk State University, Geological Faculty

3 Lenin street, Irkutsk 664003, Russia

Tel. +7(3952)511659; e-mail: chuvashova@crust.irk.ru

Чувашова Ирина Сергеевна, канд. геол.-мин. наук, с.н.с.

Институт земной коры СО РАН

664033, Иркутск, ул. Лермонтова, 128, Россия

Иркутский государственный университет, геологический факультет

664003, Иркутск, ул. Ленина, 3, Россия

Тел. +7(3952)511659; e-mail: chuvashova@crust.irk.ru

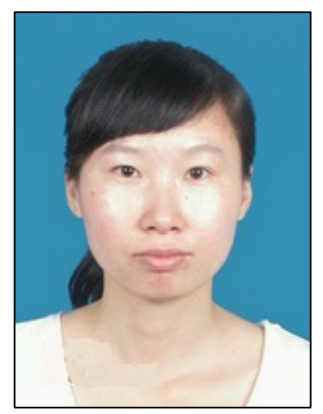

Yi-min Sun, Research assistant

Institute of Volcano and Mineral Spring, Heilongjiang Academy of Science

Wudalianchi 164155, Heilongjiang, China

e-mail: 894817259@qq.com

Йи-минь Сунь, научный сотрудник

Институт вулканов и минеральных источников Хэйлунцзянской академии наук 164155, Удаляньчи, Хэйлунцзян, Китай

e-mail: 894817259@qq.com

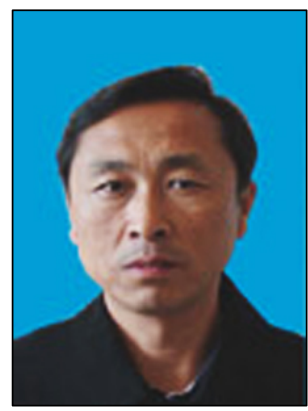

Chen Yang, Deputy director

Institute of Volcano and Mineral Spring, Heilongjiang Academy of Science

Wudalianchi 164155, Heilongjiang, China

Чэнь Янг, заместитель директора

Институт вулканов и минеральных источников Хэйлунцзянской академии наук 164155, Удаляньчи, Хэйлунцзян, Китай

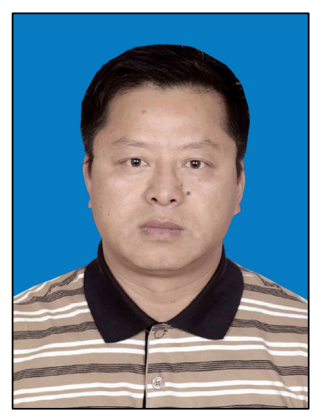

\section{Zhenhua Xie, Director}

Institute of Volcano and Mineral Spring, Heilongjiang Academy of Science

Wudalianchi 164155, Heilongjiang, China

Чжэньхуа Сие, директор

Институт вулканов и минеральных источников Хэйлунцзянской академии наук 164155, Удаляньчи, Хэйлунцзян, Китай

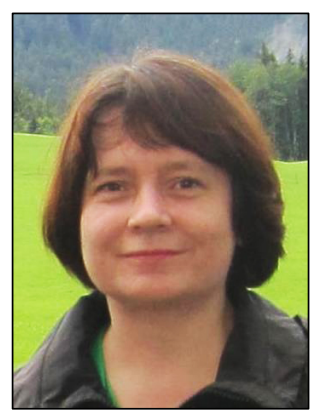

Yasnygina, Tatiana A., Candidate of Geology and Mineralogy, Senior Researcher Institute of the Earth's Crust, Siberian Branch of RAS

128 Lermontov street, Irkutsk 664033, Russia

Tel. 8(3952)511659; e-mail: ty@crust.irk.ru

Ясныгина Татьяна Александровна, канд. геол.-мин. наук, с.н.с.

Институт земной коры СО РАН

664033, Иркутск, ул. Лермонтова, 128, Россия

Тел. 8(3952)511659; e-mail: ty@crust.irk.ru 


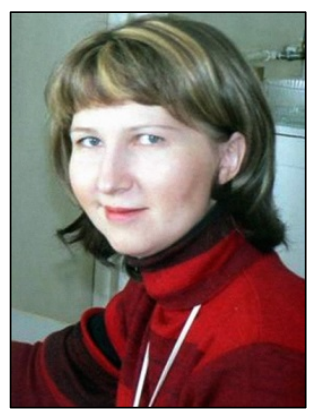

Saranina, Elena V., Candidate of Geology and Mineralogy, Senior Researcher Institute of the Earth's Crust, Siberian Branch of RAS

128 Lermontov street, Irkutsk 664033, Russia

Tel. +7(3952)511659; e-mail: saranina@crust.irk.ru

Саранина Елена Владимировна, канд. геол.-мин. наук, с.н.с.

Институт земной коры СО РАН

664033, Иркутск, ул. Лермонтова, 128, Россия

Тел. +7(3952)511659; e-mail: saranina@crust.irk.ru

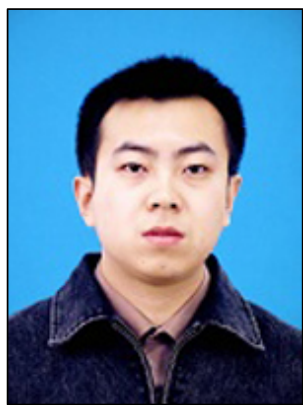

Zhenxing Fang, Deputy director

Institute of Volcano and Mineral Spring, Heilongjiang Academy of Science

Wudalianchi 164155, Heilongjiang, China

Чжэньсин Фан, заместитель директора

Институт вулканов и минеральных источников Хэйлунцзянской академии наук

164155, Удаляньчи, Хэйлунцзян, Китай 